88031069

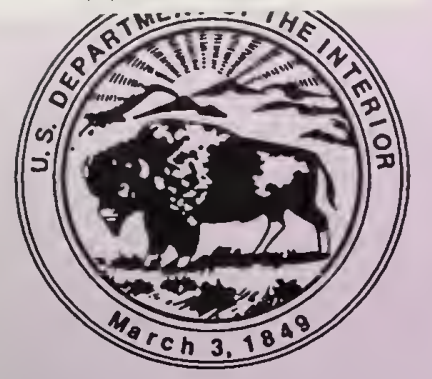

United States Department of the Interior Bureau of Land Management California Desert District

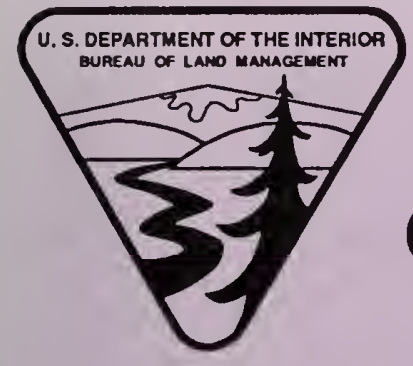

\title{
1989/1990 California Desert Conservation Area Plan Amendments Decision Record
}

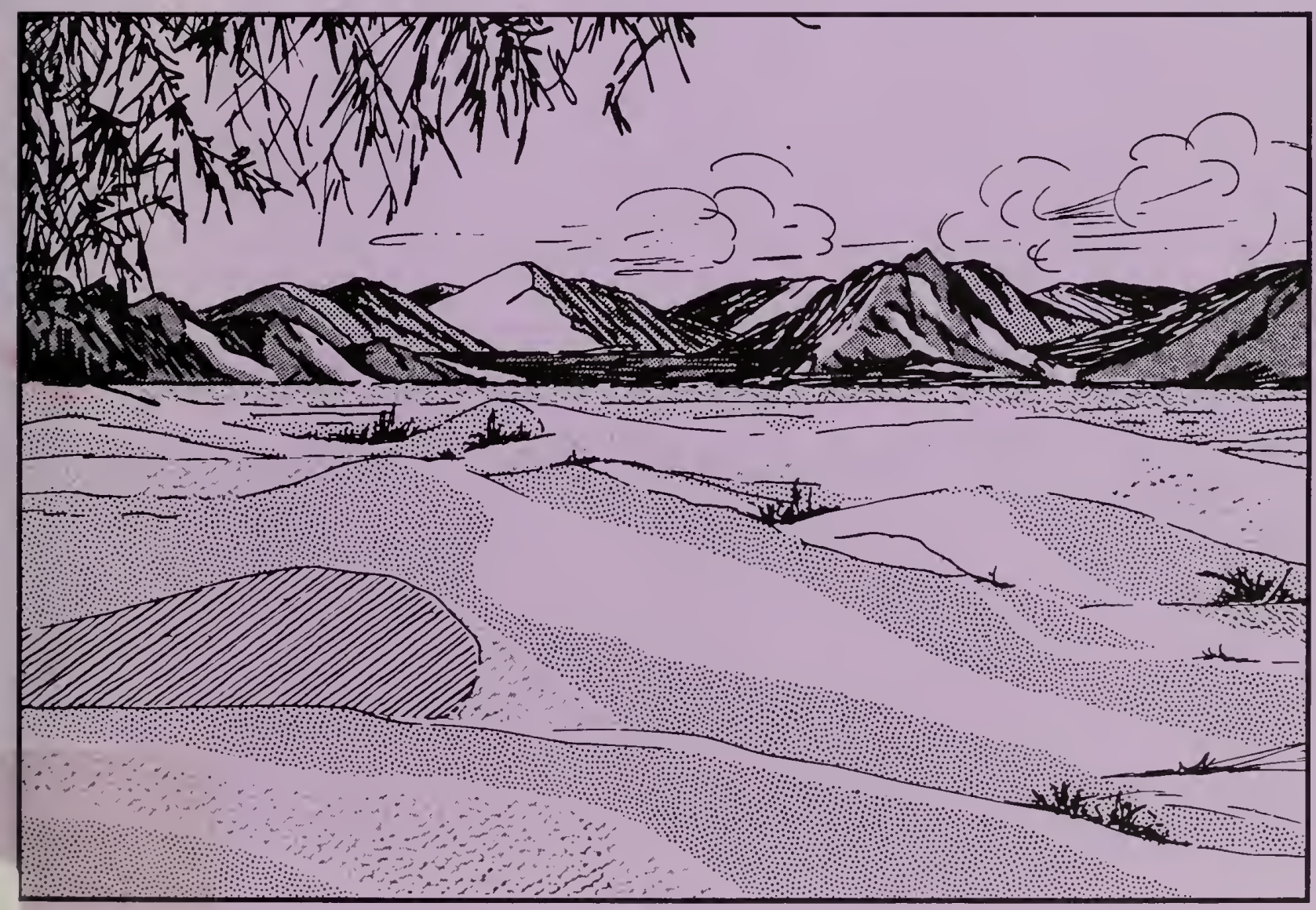




\section{BLM Mission Statement}

The Bureau of Land Management is responsible for the balanced management of Public Lands and resources and their various values so that they are considered in a combination that will best serve the needs of the American people. Management is based upon the principles of multiple use and sustained yield; a combination of uses that takes into account the long-term needs of future generations for renewable and nonrenewable resources. These resources include recreation, range, timber, minerals, watershed, fish and wildife, wilderness, and natural, scenic, scientific and cultural values.

BLM/CAPL-93/010+1610 


\title{
DECISION RECORD
}

\author{
1989/1990 CALIFORNIA DESERT
}

CONSERVATION AREA PLAN AMENDMENT

BLM LIBRARY

SC.653, BLDG. 50

DENVER FEDERAL CENTER

P. O. BOX 25047

DENVER, CO 80225-0047

\section{PREPARED BY}

Department of Interior

Bureau of Land Management

California Desert District

Riverside, California

April 1993 


\section{TABLE OF CONTENTS}

\section{DECISION RECORD/FINDING}

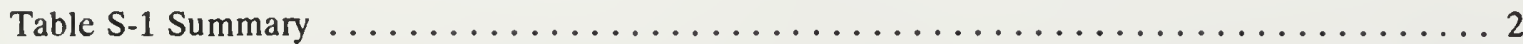

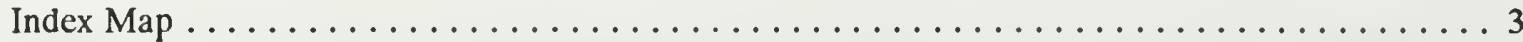

PLAN AMENDMENT DECISION $\ldots \ldots \ldots \ldots \ldots \ldots \ldots \ldots \ldots \ldots \ldots \ldots \ldots \ldots$

Amendment 1 Manix Paleontological Area ACEC ..................... 6

Amendment 2 Black Mountain Cultural Area ACEC .................

Amendment 3 Coachella Valley Fringe-Toed Lizard Preserve RNA/ACEC . . . . . . . 10

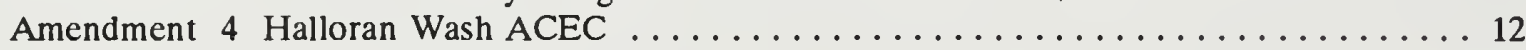

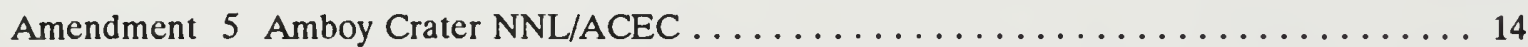

Amendment 6 Bigelow Cholla RNAVACEC $\ldots \ldots \ldots \ldots \ldots \ldots \ldots \ldots \ldots \ldots \ldots \ldots$

Amendment 7 Cima Dome ONA

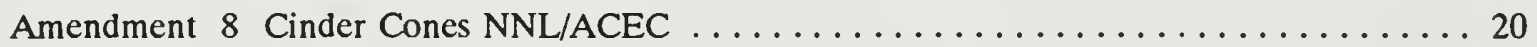

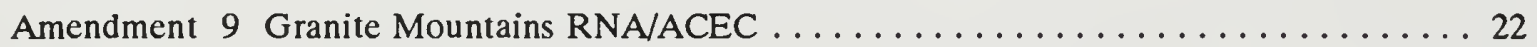

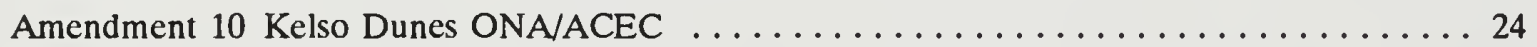

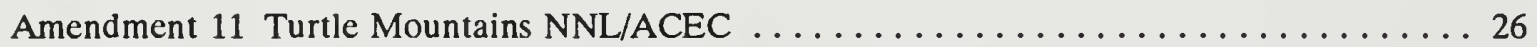

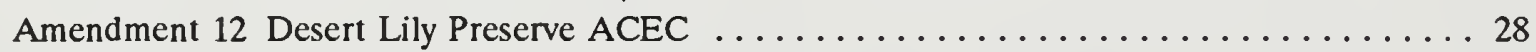

Amendment 13 North Algodones Dunes NNL/ACEC ................. 30

Amendment 14 Multiple-Use Class Change in Pipes Canyon ............... 32

Amendment 15 Multiple-Use Class Change in Arroyo Salada Open Area . . . . . . . . . 34

Amendment 16 Multiple-Use Class Change/Vehicle Access Designation in El Mirage ...... 36

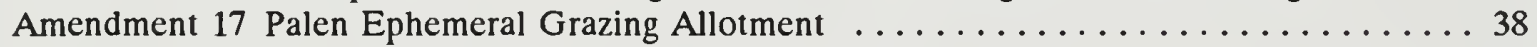

Amendment 18 Rice Valley Ephemeral Grazing Allotment . . . . . . . . . . . . . 40

Amendment 19 Desert Tortoise Management Categories Delineation .............4 42

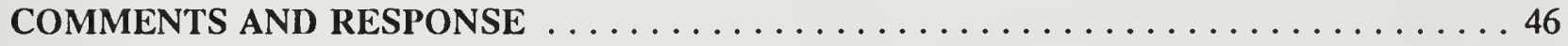

\section{APPENDICES}

Appendix A Special Area Designations Recommended for Deletion . . . . . . . . . A -1

Appendix B Amendments Dropped, Deferred, or Handled

Through Administrative Action 



\section{DECISION RECORD/FINDING}

Decision: It is my decision to amend the California Desert Conservation Area Plan by approving the 19 plan amendments described in the "Proposed Amendment" section of this decision record. Further, I approve as a plan clarification the deletion of special area designations listed in the California Desert Conservation Area Plan. The rationale for each designation's deletion is given in Appendix A.

The 1989-90 amendment review of the California Desert Conservation Area Plan was conducted in accordance with Bureau of Land Management Planning regulations (43 CFR 1610.5-5), with the procedures set forth in Chapter 7 of the CDCA Plan (1980), and with the Council of Environmental Quality regulations for implementing the National Environmental Policy Act (40 CFR 1500).

Alternatives: Of the 19 proposed amendments, 18 proposed amendments had two alternatives; one proposed amendment (Amendment \#1) had five alternatives. For each amendment, a BLM preferred alternative was indicated and analyzed along with the other alternative(s) in an Environmental Assessment distributed for public review. As a result of public comment and internal review of the proposed amendments, the following change was made: the preferred amendment for Amendment \#4, Halloran Wash ACEC has been changed from deleting the ACEC designation to No Action, i.e., continue the ACEC designation. The initial proposal to delete the Halloran Wash ACEC designation was based on available information. An evaluation of public comment indicated that the proposed decision to delete the ACEC designation was premature without further survey and evaluation of extant cultural resources. Pending such survey and evaluation the preferred alternative for Amendment \#4 is No Action, continuation of the Halloran Wash ACEC.

Public Review and Scoping: A Notice of Intent to conduct a Desert Plan review was published in the Federal Register (January 12, 1989), and an invitation for proposals was sent to the Desert Plan mailing list (February 8, 1989) with a final date for submitting proposals being March 10, 1989. Thirty-one amendments were proposed by the public and the BLM staff. They were screened by BLM management and by the California Desert District Advisory Council to determine which should be considered at this time and which should be deferred, dropped, or handled by an administrative action (see Appendix B). Nineteen proposals were accepted for consideration (see Map 1 for regional location). The proposed plan amendments and environmental assessment were distributed for a sixty day public review period which concluded on December 16, 1991. The public review resulted in sixteen comment letters. All letters and responses to specific comments are presented in the "Comment and Response" section of this Decision Record.

Finding of No Significant Impact: Based on analysis of potential environmental impacts contained in the environmental assessment, it has been determined that impacts are not expected to be significant and an environmental impact statement is not required.

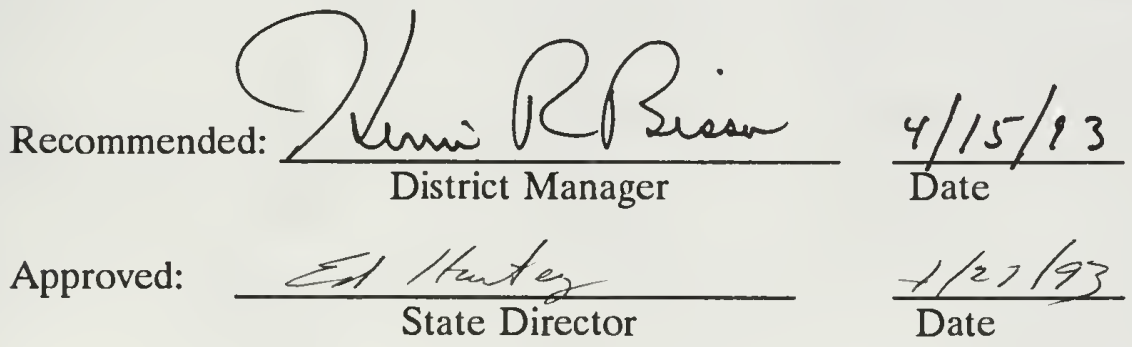


TABLE S-1

SUMMARY COMPARISON OF "NO ACTION" AND PREFERRED ALTERNATIVE

Resource

Unit of

Measure

No Action

Preferred

Percent

New \%

Multiple Use Class

$\mathrm{C}^{*}$
$\mathrm{~L}$
$\mathrm{M}$
$\mathrm{I}$

Unclassified

Total

Vehicle Access

Open

Limited

Closed

Undesignated

$\underline{\text { Total }}$

\section{ACECs}

Added

Expanded

Deleted**

Net Change
Acres

Acres

Acres

Acre

Acres

Acres

Acres

Acres

Acres

$$
\begin{array}{r}
513,150 \\
9,437,460 \\
1,969,390 \\
251,000 \\
\hline 12,171,000
\end{array}
$$

Change of Desert
15.9

51.4

26.4

4.4

1.9

$\overline{100.0}$

$12,171,000$

\section{Livestock Grazing}

Ephemeral Allotments Number Acres

Ephemeral/Perennial Number Allotments

Perennial Allotments
Number

Acres

Number

Acres

Number

Acres

Number

Acres
77.3

16.4

2.0

$$
\begin{array}{r}
517,410 \\
9,450,000 \\
1,969,390 \\
234,200 \\
\hline 12,171,000
\end{array}
$$

0.83

0.14

0.00

$-6.7$

100.0
Number

Number

Acres
19 $1,315,820$

25

$3,036,270$

14

720,520
10

177,062 2
26,150 1 $-1,920$

9

198,800

*MUC "C" acreage measurements were refined during final wilderness study reporting.

** Mopah Springs ACEC will be incorporated into the Turtle Mountains NNL/ACEC. 


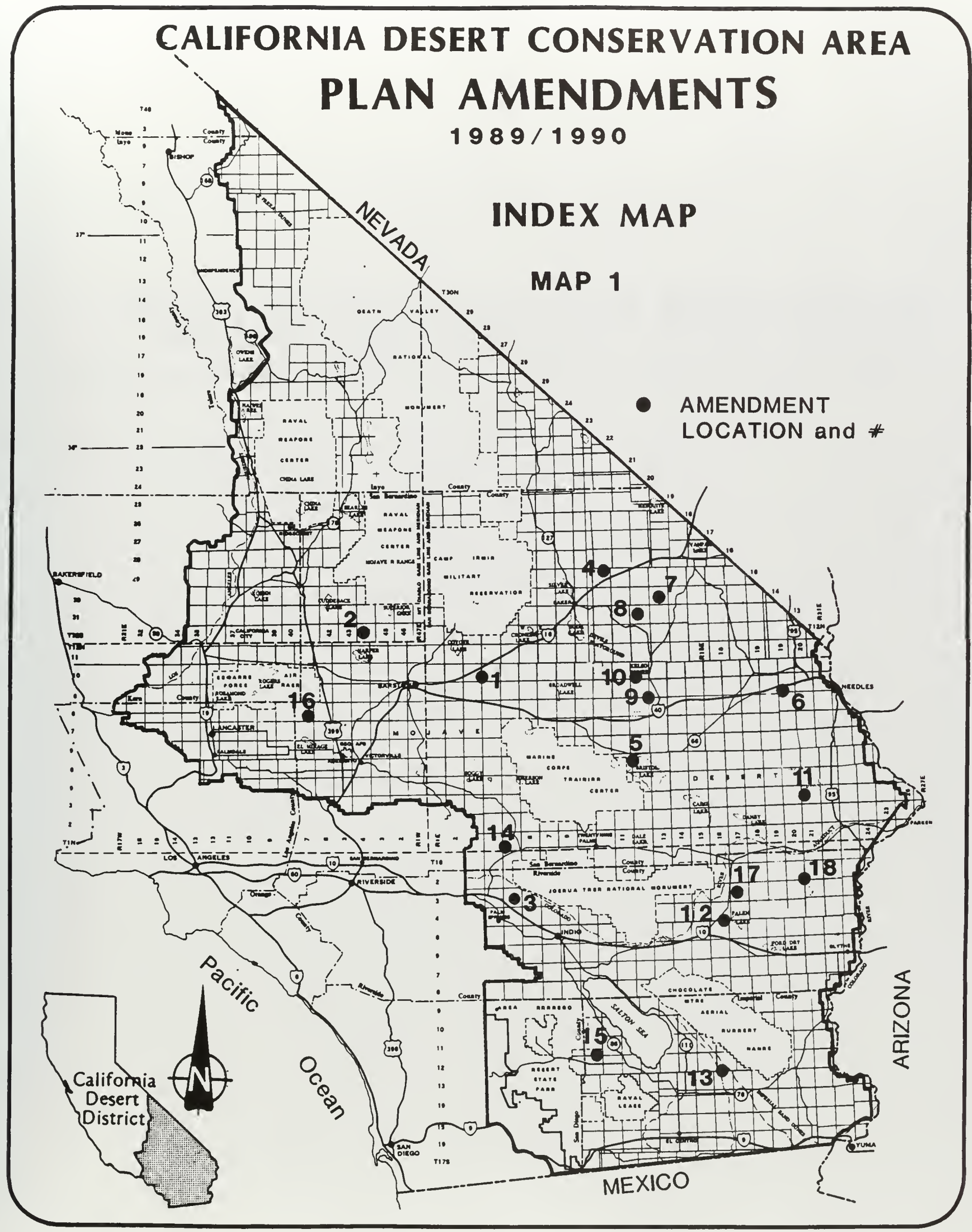




\section{Plan Amendment Decision}




\section{AMENDMENT ONE \\ MANIX PALEONTOLOGICAL AREA ACEC}

\section{Proposed Amendment}

Designate as the Manix Paleontological Area ACEC 2,950 acres of public lands 25 miles east of Barstow along the Mojave River containing known fossil sites. Management of the ACEC will focus on the preservation and protection of the scientific and research values associated with the paleontological resources found in the area. Existing authorized users and uses will be allowed to continue, including grazing, recreation, and mining. Currently authorized or designated access routes shall remain open and available for use. Any modifications, expansions, and/or maintenance of facilities by authorized users will require review and approval by the BLM.

\section{Other Alternatives Considered}

Alternative A: Designate as the Manix Paleontological Area ACEC 3,900 acres of public land and 1,700 acres of private land. Management would be the same as for the Proposed Amendment.

Alternative B: Designate as the Manix Paleontological Area ACEC 3,900 acres of public lands. - Management would be the same as for the Proposed Amendment.

Alternative D: Do not designate the Manix area as an ACEC, but change the multiple-use class of the 3,900 acre area of public land from "M" to "L". Management would be in accordance with multiple-use class "L" guidelines.

Alternative E: No Action. Continue to manage the area in accordance with multiple-use class "M" guidelines.

\section{Decision}

Adopt the Proposed Amendment.

\section{Rationale}

The paleontological resources found in the Manix area meet the ACEC criteria of relevance and importance and warrant special management attention. The 2,950 acre ACEC contains most of the known Pleistocene paleontological resources, is adequate to protect the major resource values, and minimizes impacts to other users. Peripheral Manix Lake deposits are excluded from the ACEC.

\section{Implementation Needs}

Prepare ACEC management plan. 


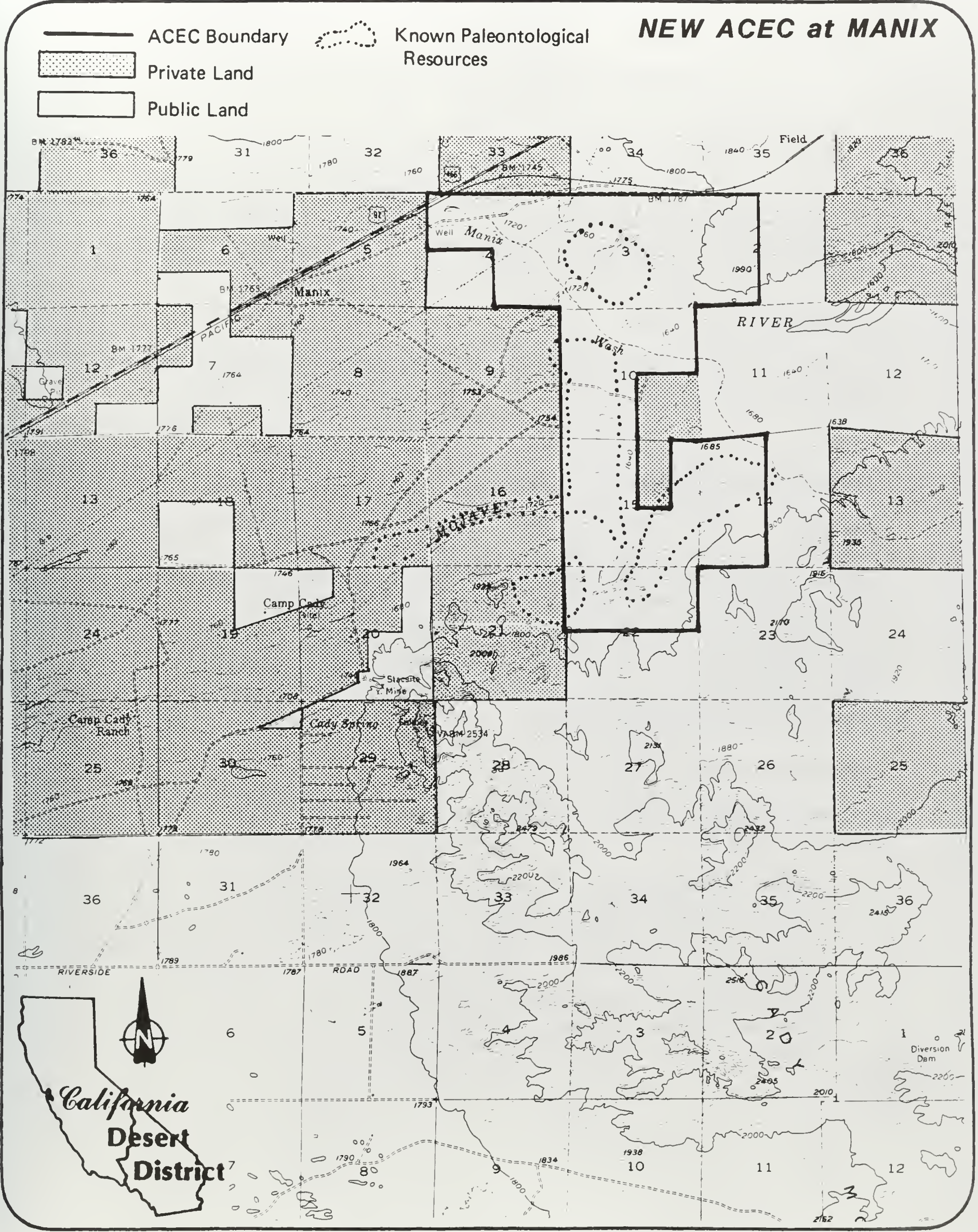




\section{AMENDMENT TWO \\ BLACK MOUNTAIN CULTURAL AREA ACEC}

\section{Proposed Amendment}

Enlarge the 5,120-acre Black Mountain Cultural Area ACEC (\#35) by adding 32,480 acres (17,920 acres public lands, 13,120 acres private lands, and 1,440 acres State lands). The ACEC will be managed in accordance with the Black Mountain Cultural Area ACEC Management Plan (1988) which prescribed special management measures to protect cultural resources in the enlarged area.

\section{Other Alternatives Considered}

No Action: Continue to manage the area surrounding the existing ACEC in accordance with multiple-use class "L" guidelines.

\section{Decision}

Adopt the Proposed Amendment.

\section{Rationale}

In preparing a management plan for the Black Mountain Cultural Area ACEC, Bureau archaeologists found that extraordinary cultural resources extended well beyond the original ACEC boundary, including but not limited to extensive assemblages of petroglyphs, lithic workshops, locations suitable for surface occupation sites and game hunting, and a major transportation corridor used by prehistoric peoples. The management plan, completed in 1988, proposed enlargement of the ACEC boundary. The cultural resources in the enlarged area meet the ACEC criteria of relevance and importance and warrant special management attention.

\section{Implementation Needs}

Implement the actions prescribed in the 1988 management plan for the Black Mountain Cultural Area ACEC as follows:

* Acquire, through exchange, State and private lands within the expanded ACEC boundary.

* $\quad$ Monitor and enforce closure of selected routes of travel.

* Use barriers and signs to direct vehicles away from sensitive cultural resources

* Research cultural resources through survey and potential data recovery (when necessary).

* Increase ranger patrol.

* Nominate properties to National Register of Historic Places

* Withdraw significant rock art sites from mineral entry (approximately 500 acres). 


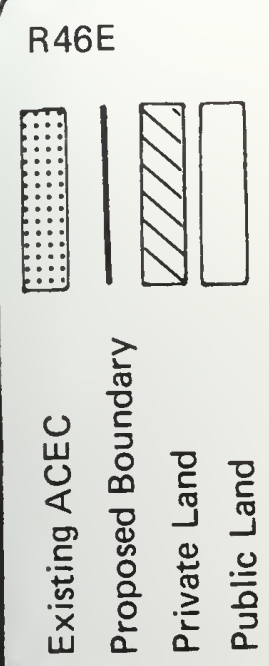

35 BLACK MOUNTAIN ACEC Enlarge Boundary

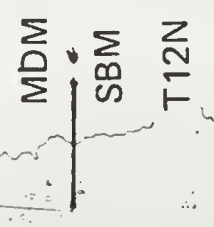

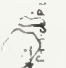




\section{AMENDMENT THREE \\ COACHELLA VALLEY FRINGE-TOED LIZARD PRESERVE RNA/ACEC}

\section{Proposed Amendment}

Combine the 1,694-acre Edom Hill-Willow Hole ACEC (\#79) with the Coachella Valley Preserve (7,000 acres) and the Whitewater Floodplain (Indian Avenue) Preserve (1,230 acres) to form the 9,924-acre Coachella Valley Fringe-Toed Lizard Preserve RNA/ACEC. Management of the ACEC will primarily focus on the protection and recovery of the Coachella Valley Fringe-Toed Lizard (Uma inornata), a Federally-listed "threatened" species and a State-listed "endangered" species.

\section{Other Alternatives Considered}

No Action: Maintain the Edom Hill-Willow Hole Preserve ACEC and manage the three areas in accordance with the Coachella Valley Preserve System Management Plan (1986).

\section{Decision}

Adopt the Proposed Amendment.

\section{Rationale}

The consolidation of the two preserves and an existing ACEC, creating a single management entity for the Coachella Valley Fringe-Toed Lizard (CVFTL), will improve management of the habitat for this Federally listed species. It also implements recommendations in the Habitat Conservation Plan (1985) and the Coachella Valley Preserve System Management Plan (1986). The three areas contain the ecosystems needed to support the CVFTL as well as other sensitive plants and animals including the Least Bell's Vireo which is Federally and State-listed as endangered and two Federal candidate plant species, archaeological resources and cultural values. The resource values in the three areas meet the ACEC criteria of relevance and importance and warrant special management attention.

\section{Implementation Needs}

Update and implement the management plan for the ACEC, including the following actions:

* Eliminate the OHV trespass problem by fencing, signing, enforcement of road closures, patrolling and public education.

* Remove exotic plants, including salt cedar (Tamarix-pentandra) and athel (Tamarix aphylla) by cutting and application of herbicides; monitor Russion thistle and consider removal; all herbicide use will be conducted in accordance with BLM vegetation management policies and with site-specific environmental analysis.

* Remove abandoned buildings.

* Develop hiking and equestrian trails.

* $\quad$ Prepare and distribute educational brochures.

* Monitor rare plant and animal species. 
AMENDMENT 3

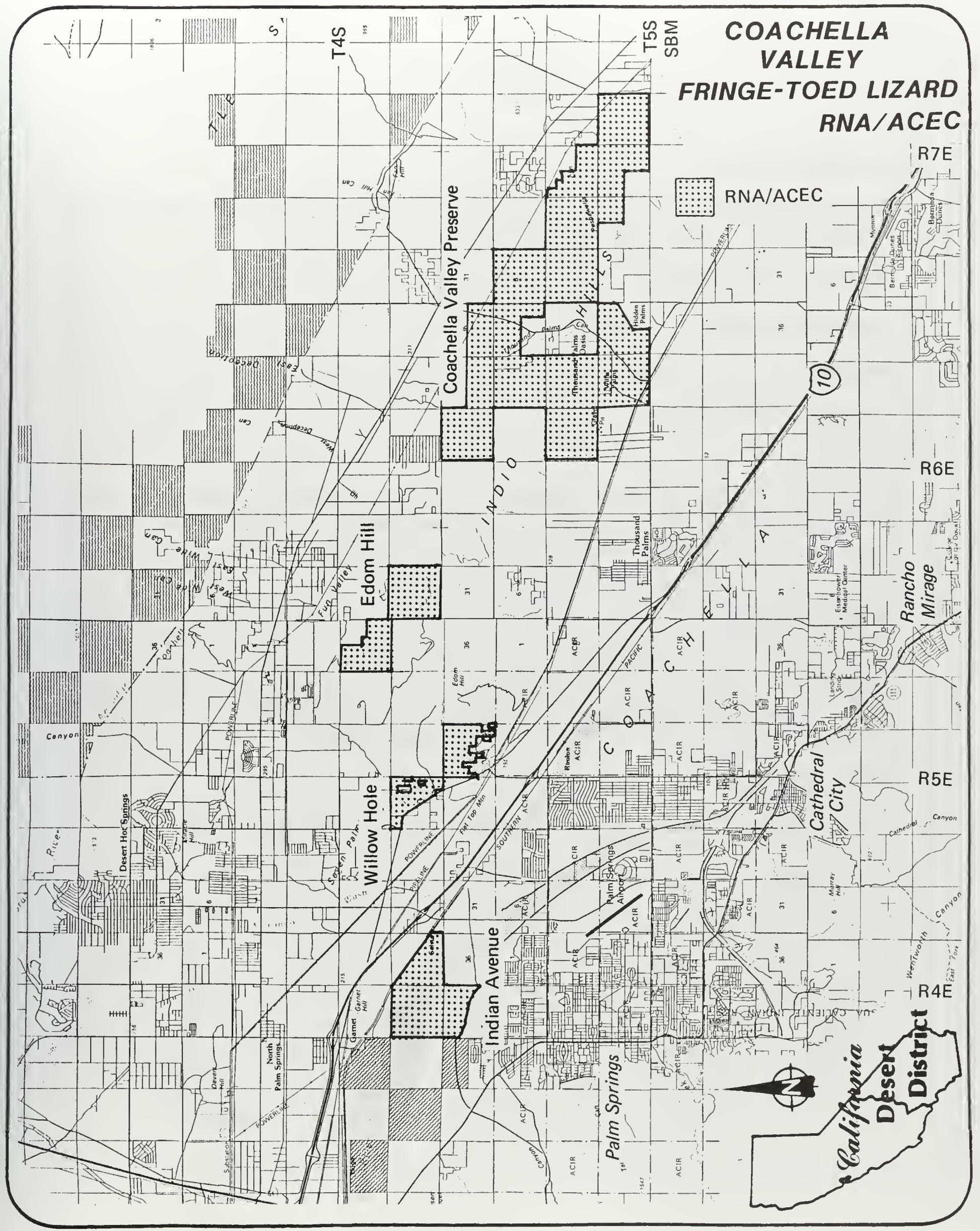




\section{AMENDMENT FOUR \\ HALLORAN WASH ACEC}

\section{Proposed Amendment}

No Action: Maintain the Halloran Wash ACEC (\#29) designation and continue to manage the area in accordance with ACEC management guidelines.

\section{Other Alternatives Considered}

Delete the Halloran Wash ACEC (\#29).

\section{Decision}

Adopt Proposed Amendment.

\section{Rationale}

This area was originally designated as an ACEC in recognition of its potential to yield data pertaining to Anasazi turquoise mines, which had been found on adjacent lands. No such resources have been found on public lands within the ACEC. In 1982 the ACEC was expanded to include an area thought to contain petroglyphs, however, recent on-site examination showed that the petroglyphs are on private land outside the ACEC boundary while other petroglyphs are partially on public land. A proposal to eliminate the ACEC designation was based on evidence that the resources within the ACEC boundary did not meet the criteria of relevance and importance. Internal and external concerns were raised regarding the adequacy of the data upon which we were basing our recommendation to delete the ACEC designation. It was decided that before reconsidering the ACEC designation, further survey within the ACEC and evaluation of cultural resources on public land are necessary to determine if the values warrant continuation under ACEC management.

\section{Implementation Needs}

Conduct complete survey and evaluation of cultural resources in the Halloran Wash ACEC. 


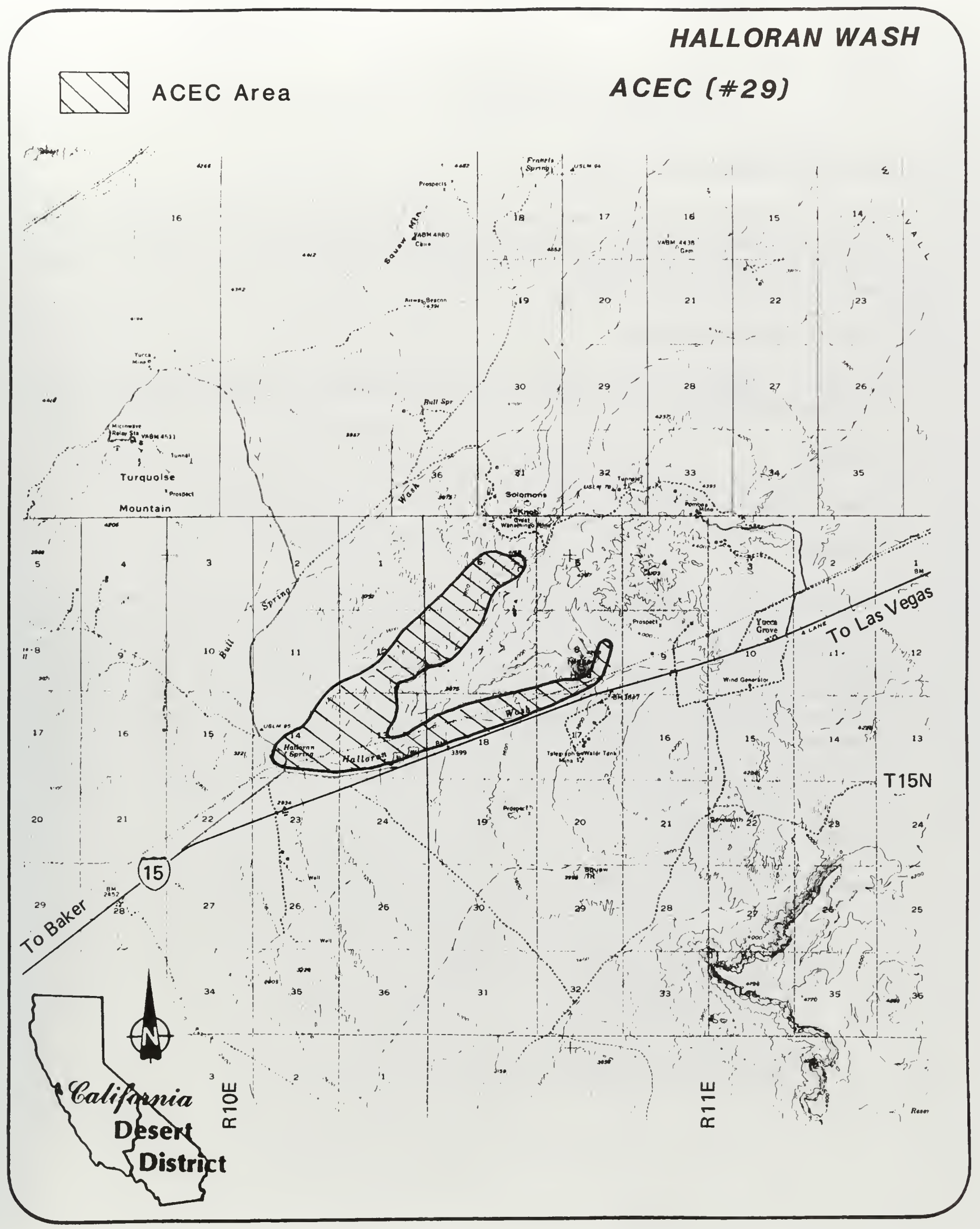




\section{AMENDMENT FIVE \\ AMBOY CRATER NATIONAL NATURAL LANDMARK ACEC}

\section{Proposed Amendment}

Designate the Amboy Crater and its surrounding areas, located in San Bernardino County 2.5 miles west of the community of Amboy, as a National Natural Landmark ACEC. The total area of the ACEC is 640 acres. The area would be managed under the Amboy Crater National Natural Landmark Management Plan (1987).

\section{Other Alternatives Considered}

No Action: Continue to manage the area in accordance with the National Natural Landmark Management Plan (1987).

\section{Decision}

Adopt Proposed Amendment.

\section{Rationale}

Prior to the passage of FLPMA, the Bureau of Land Management used a variety of designations to identify areas with unique or outstanding values. To eliminate the proliferation of terms, California BLM developed the ACEC "umbrella" concept, under which all special area will be designated as ACECs provided they meet the ACEC criteria. Special areas in the CDCA have been reviewed to determine their eligibility for ACEC designation. In 1987 the BLM evaluated the 5,760 acre area which included the Amboy Crater cinder cone and the entire lava flow. It was determined that the significant part of the area was the cinder cone and the area immediately surrounding it. The 640 acre area includes the most significant resources associated with the Amboy Crater. These resources meet the ACEC criteria of relevance and importance and warrant special management attention.

\section{Implementation Needs}

Implement the Amboy Crater National Natural Landmark Management Plan, as follows:

* Withdraw entire area from mineral entry under the Mining Law of 1872.

* Enforce closure of the area to firearm use.

* Provide interpretive signing.

* Construct small day-use facility.

* $\quad$ Prevent vehicle access beyond the day use site.

* Restore north face of cinder cone.

* Provide interpretive trail to the top of the cone. 


\section{Amboy Crater NNL/ACEC}

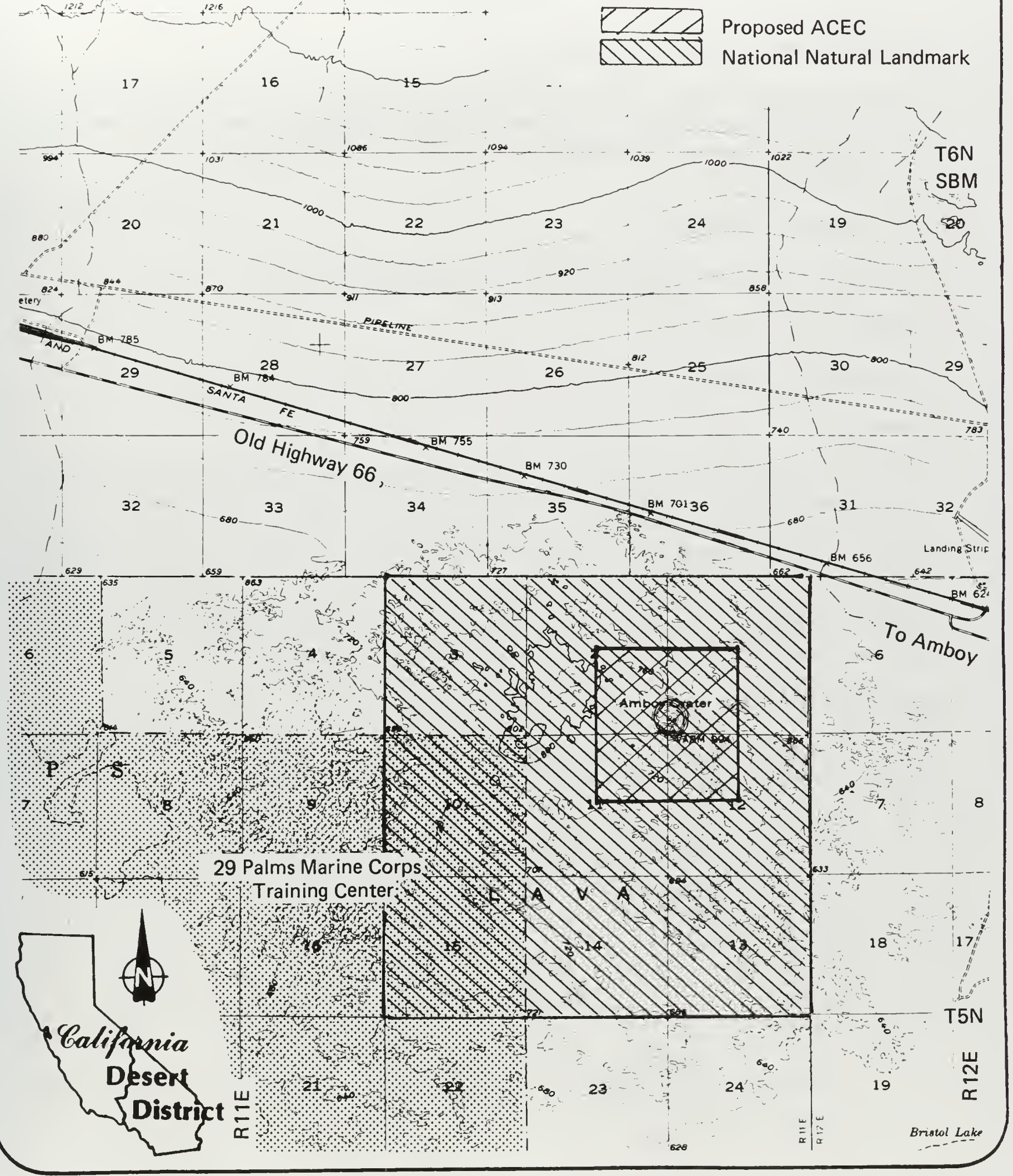




\section{AMENDMENT SIX \\ BIGELOW CHOLLA RNA/ACEC}

\section{Proposed Amendment}

Designate the 80 -acre Bigelow (Teddy Bear) Cholla as a Research Natural Area (RNA)/ACEC. The area lies on both sides of Interstate 40 in the Sacramento Mountains adjacent to land owned by the University of California as part of its Natural Reserve System. The area shall be managed primarily for research purposes.

\section{Other Alternatives Considered}

No Action: Continue management of area under multiple-use class " $\mathrm{M}$ ".

\section{Decision}

Adopt Proposed Amendment

\section{Rationale}

Prior to the passage of FLPMA, the Bureau of Land Management used a variety of designations to identify areas with unique or outstanding values. To eliminate the proliferation of terms, California BLM developed the ACEC "umbrella" concept, under which all special areas will be designated as ACECs provided they meet the ACEC criteria. Special areas in the CDCA have been reviewed to determine their eligibility for ACEC designation. The Bigelow Cholla was managed as a Natural Area. It contains the northern-most population and the densest-known concentration of Bigelow Cholla in the CDCA. The resource values have been determined to meet the ACEC criteria of importance and relevance, and the resources and values require special attention.

\section{Implementation Needs}

Develop a Memorandum of Understanding with the University of California to address cooperative research activities in the area and to serve as the ACEC management plan. 


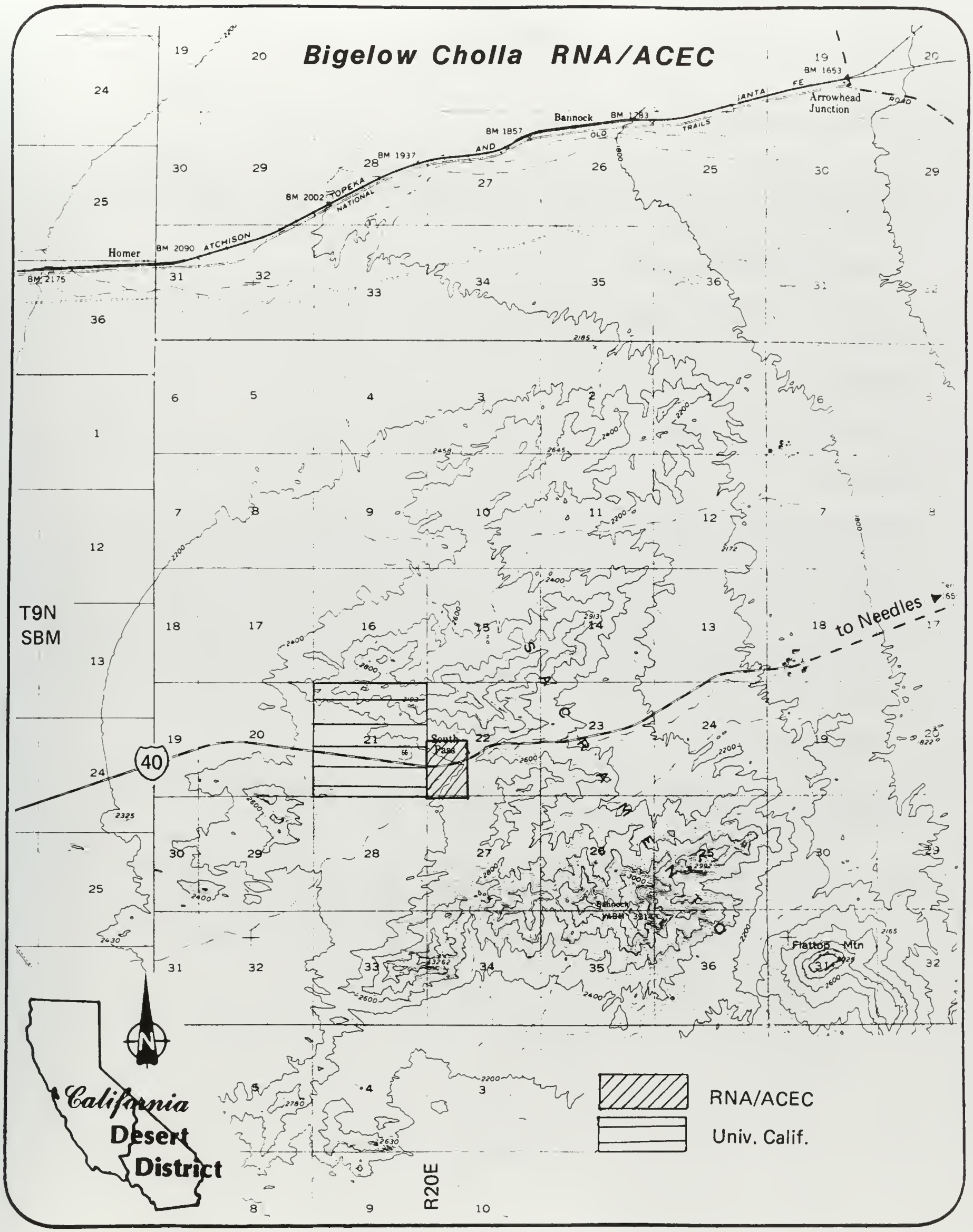




\section{AMENDMENT SEVEN \\ CIMA DOME ONA/ACEC}

\section{Proposed Amendment}

Designate 18,640 acres of public land encompassing the Cima Dome as an Outstanding Natural Area (ONA)/ACEC. The ACEC shall be managed to protect the outstanding Joshua Tree forest and other important resources.

\section{Other Alternatives Considered}

No Action: Continue to manage area as specified in the East Mojave National Scenic Area Plan (1988).

\section{Decision}

Adopt Proposed Amendment.

\section{Rationale}

Prior to the passage of FLPMA, the Bureau of Land Management used a variety of designations to identify areas with unique or outstanding values. To eliminate the proliferation of terms, California BLM developed the ACEC "umbrella" concept, under which all special areas will be designated as ACECs. Special areas in the CDCA have been reviewed to determine their eligibility for ACEC designation. Cima Dome designation meets the ACEC criteria of importance and relevance, and the resources and values require special attention. The incorporation of the ONA into an ACEC will provide additional visibility to ensure its protection under the existing East Mojave National Scenic Area Plan (1988).

\section{Implementation Needs}

Implement management actions prescribed in the East Mojave National Scenic Area Plan which are applicable to Cima Dome, including the following:

* Maintain the withdrawal from mineral entry under the mining laws on 18,320 acres.

* Withdraw the remaining 320 acre Wildcat Butte area from mineral entry.

* Acquire one section of State land within the ACEC boundary through exchange.

* Close several routes to protect natural values in the Joshua Tree woodland.

* Test springs routinely.

* Develop and maintain hiking trails through the ACEC. 


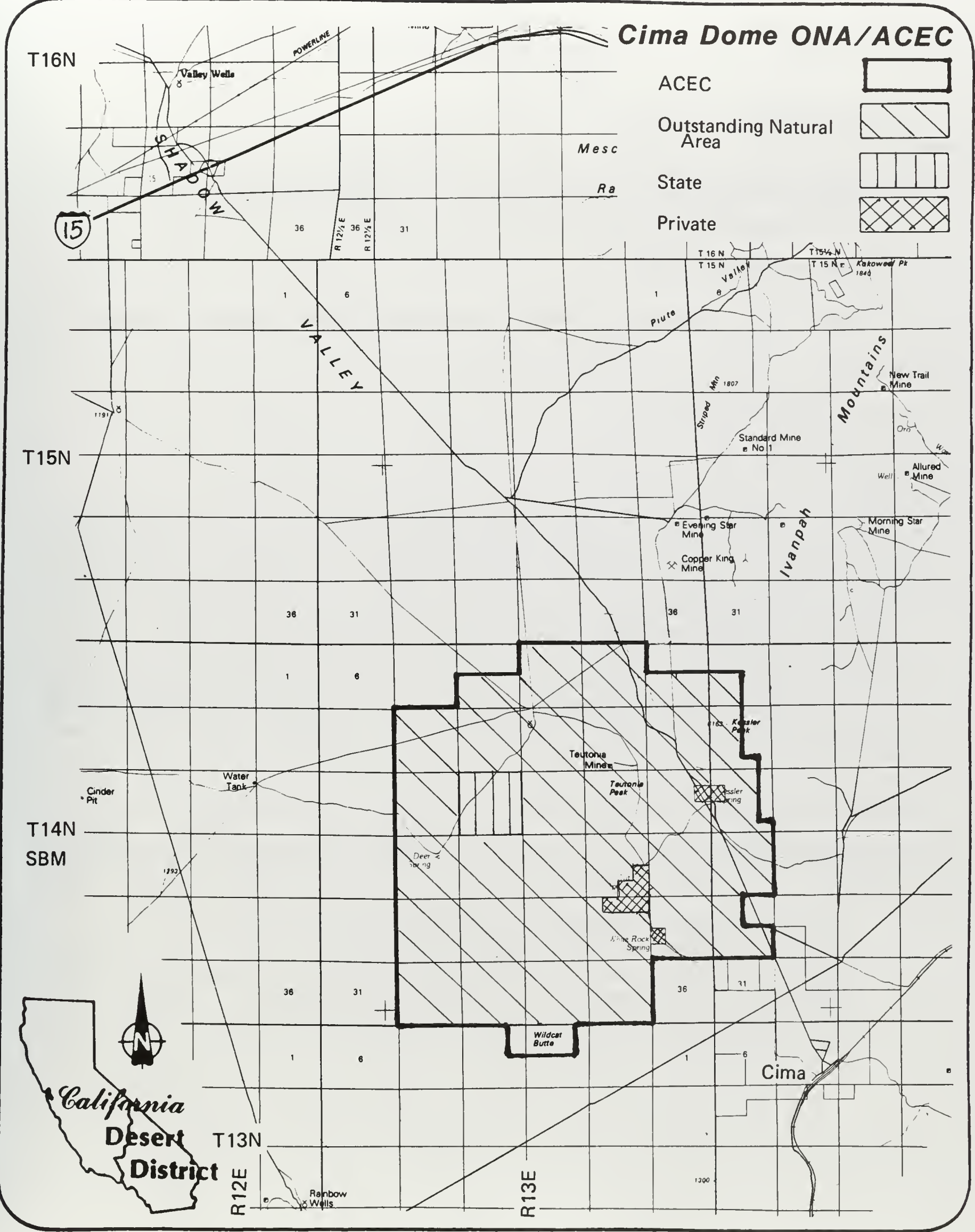




\section{AMENDMENT EIGHT CINDER CONES NNL/ACEC}

\section{Proposed Amendment}

Designate the 24,320-acre Cinder Cones NNL and 640 acres adjacent to the east border as a National Natural Landmark (NNL)/ACEC. The ACEC shall be managed for the protection of the volcanic cones and other geologic and cultural resources in the vicinity.

\section{Other Alternatives Considered}

No Action: Continue to manage area under the East Mojave National Scenic Area Plan (1988).

\section{Decision}

Adopt Proposed Amendment.

\section{Rationale}

Prior to the passage of FLPMA, the Bureau of Land Management used a variety of designations to identify areas with unique or outstanding values. To eliminate the proliferation of terms, California BLM developed the ACEC "umbrella" concept, under which all special areas will be designated as ACECs. Special areas in the CDCA have been reviewed to determine their eligibility for ACEC designation. The Cinder Cones area was designated as a National Natural Landmark in 1975. Part of the area had previously been designated an Outstanding Natural Area. The resources in the area, including extensive lava flows interspersed with numerous dormant volcanic cones which are noted for their petroglyph-covered basalts, meet the ACEC criteria of importance and relevance, and the resources and values require special attention. The incorporation of the ONA into an ACEC will provide additional visibility to ensure its protection under the existing East Mojave National Scenic Area Plan (1988).

\section{Implementation Needs}

Implement management actions prescribed in the East Mojave National Scenic Area Plan which are applicable to Cinder Cones, including the following:

* Maintain withdrawal from mineral entry on 4,800 acres.

* Withdraw from mineral entry an additional 15, 320 acres.

* Acquire 1,280 acres of state land through exchange within the proposed ACEC boundary.

* Close several vehicle routes to protect cultural and natural values.

* Limit the extraction of mineral materials (sand, gravel, cinders) to the amount required by local governments. 


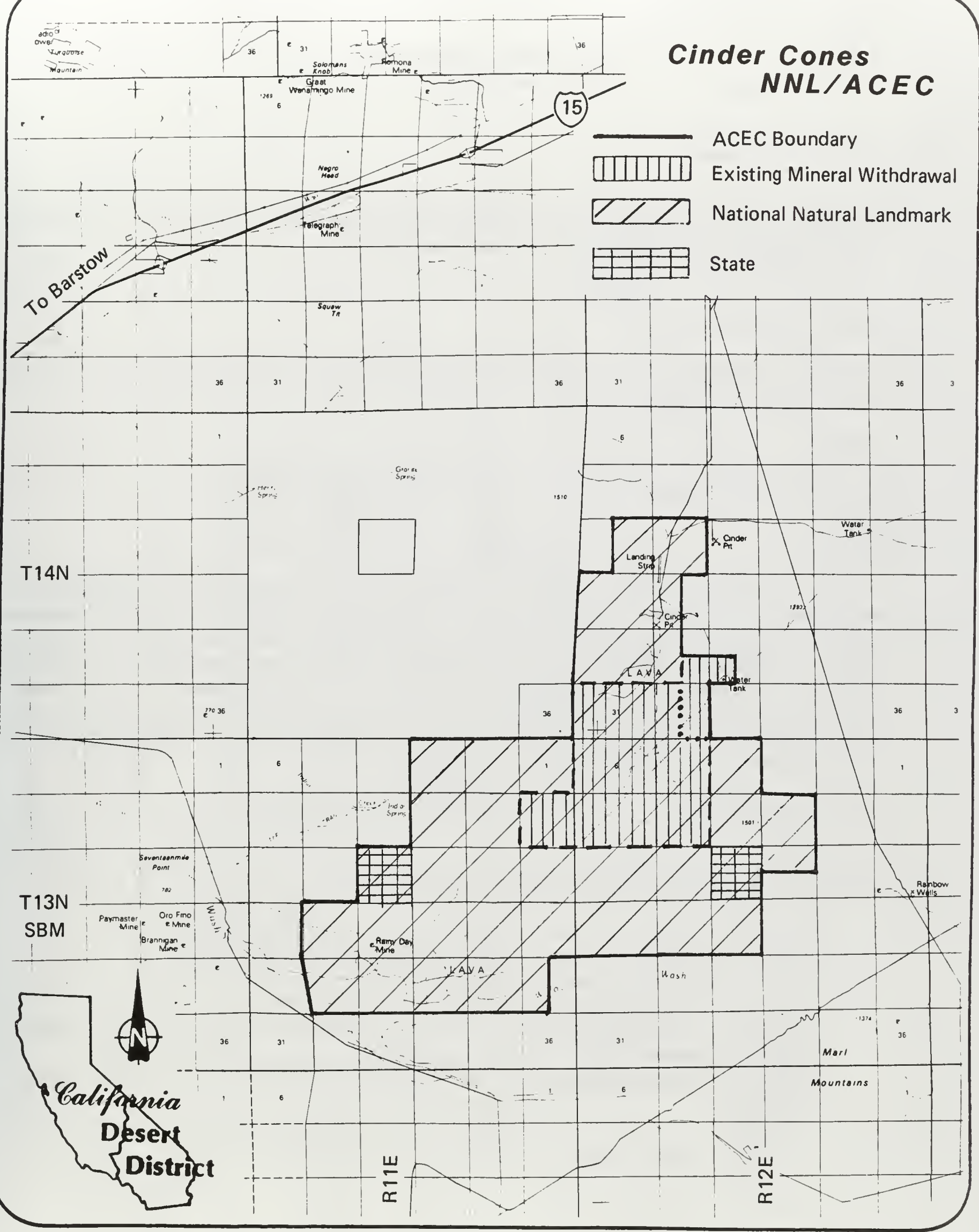




\section{AMENIDMENT NINE \\ GRANITE MOUNTAINS RNA/ACEC}

\section{Proposed Amendment}

Designate 6,680 acres in the Granite Mountains as a Research Natural Area (RNA)/ACEC. The public land in the area is intermingled with lands owned by the University of California (UC) and is jointly managed by the BLM and UC for research and protection of an unusually diverse range of vegetation and wildlife.

\section{Other Alternatives Considered}

No Action: Continue to manage with the University of California, in compliance with the East Mojave National Scenic Area Plan guidelines.

\section{Decision}

Adopt Proposed Amendment.

\section{Rationale}

Prior to the passage of FLPMA, the Bureau of Land Management used a variety of designations to identify areas with unique or outstanding values. To eliminate the proliferation of terms, California BLM developed the ACEC "umbrella" concept, under which all special areas will be designated as ACECs. Special areas in the CDCA have been reviewed to determine their eligibility for ACEC designation. The diversity of biological resources in the Granite Mountains meet the ACEC criteria of importance and relevance, and the resources and values require special attention. The incorporation of the RNA into an ACEC will provide additional visibility to ensure its protection under the existing East Mojave National Scenic Area Plan (1988).

\section{Implementation Needs}

Implement management actions prescribed in the East Mojave National Scenic Area Plan which are applicable to the Granite Mountains, including the following:

* Acquire one State section inside the ACEC boundary through exchange.

* Maintain withdrawal from mineral entry for 520 acres within the ACEC.

* Withdraw from mineral entry the remaining 6,160 acres.

* Close several vehicle routes to protect cultural and natural resources.

* Continue a no-shooting zone to include the entire RNA/ACEC in order to protect researchers and recreationists.

* Maintain a Cooperative Agreement with the University of California to jointly manage the RNA/ACEC. 


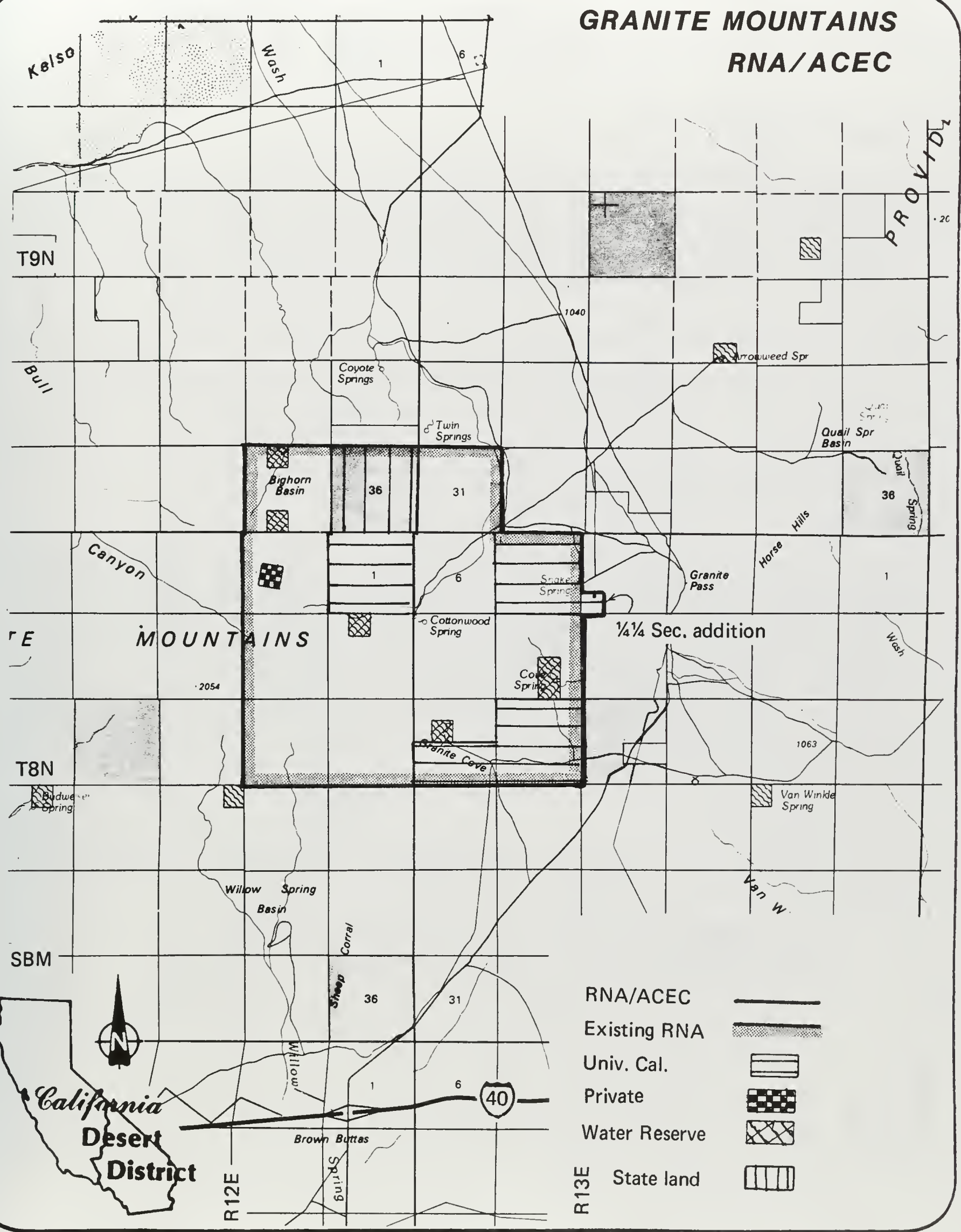




\section{AMENDMENT TEN \\ KELSO DUNES ONA/ACEC}

\section{Proposed Amendment}

Designate 49,065 acres of the Kelso Sand Dunes as an Outstanding Natural Area (ONA)/ACEC. The ACEC boundaries would coincide with the boundaries of the Kelso Sand Dunes Wilderness Study Area (CDCA-250) which has been recommended for wilderness designation. The area would be managed to protect the unique dunes ecosystem with great species diversity found in the visually spectacular Kelso Dunes, one of the three tallest dunes systems in North America.

\section{Other Alternatives Considered}

No Action: Continue to manage under the East Mojave National Scenic Area Management Plan.

\section{Decision}

Adopt Proposed Amendment.

\section{Rationale}

Prior to the passage of FLPMA, the Bureau of Land Management used a variety of designations to identify areas with unique or outstanding values. To eliminate the proliferation of terms, California BLM developed the ACEC "umbrella" concept, under which all special areas will be designated as ACECs. Special areas in the CDCA have been reviewed to determine their eligibility for ACEC designation. Kelso Dunes had previously been designated in 1972 as an Outstanding Natural Area. The Kelso Dunes with their unique flora and fauna meet the ACEC criteria of importance and relevance, and the resources and values require special attention. The incorporation of the ONA into an ACEC will provide additional visibility to ensure its protection under the existing East Mojave National Scenic Area Management Plan (1988).

\section{Implementation Needs}

Implement management actions prescribed in the East Mojave National Scenic Area Plan which are applicable to the Kelso Dunes, including the following:

* Maintain withdrawal from mineral entry throughout the area.

* Maintain closure to motorized vehicle use. 


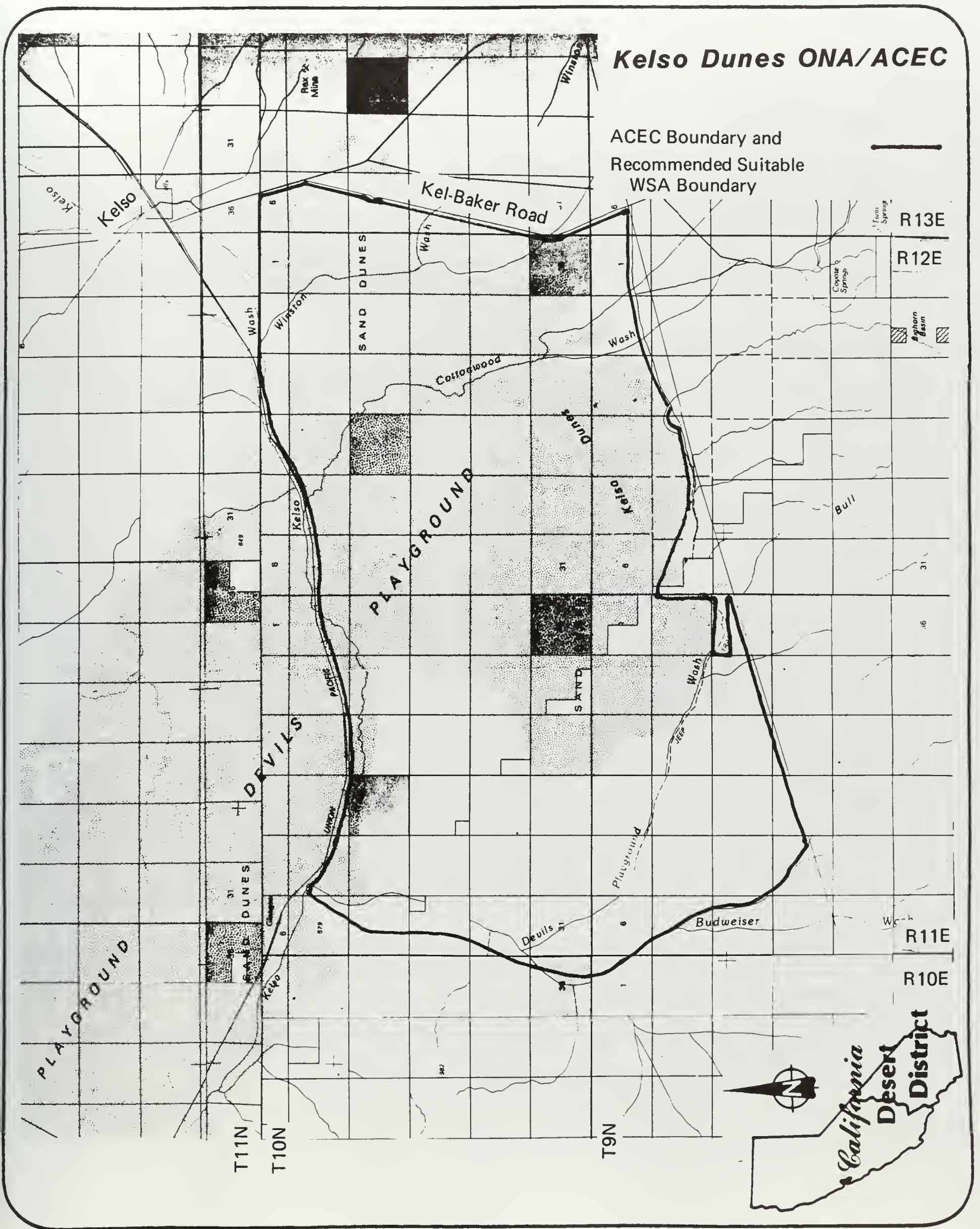




\section{AMENDMENT ELEVEN \\ TURTLE MOUNTAINS NNL/ACEC}

\section{Proposed Amendment}

Designate 44,160 acres in the Turtle Mountains as a National Natural Landmark (NNL)/ACEC. The ACEC would occupy the same area as the vehicle closure area established in 1976. The boundaries would encompass the central core of the Turtle Mountains, including the Mopah Springs ACEC (\#75) and a large portion of the Turtle Mountain Wilderness Study Area (CDCA-307) which was recommended for wilderness designation. The area will be managed for the protection of the fragile and unique environment, including some of the most distinctive volcanic formations in the California Desert.

\section{Other Alternatives Considered}

No Action: Continue management under guidelines of BLM's Interim Management Policy for Lands Under Wilderness Review and continuation of the vehicle closure.

\section{Decision}

Adopt Proposed Amendment.

\section{Rationale}

Prior to the passage of FLPMA, the Bureau of Land Management used a variety of designations to identify areas with unique or outstanding values. To eliminate the proliferation of terms, California BLM developed the ACEC "umbrella" concept, under which all special areas will be designated as ACECs. Special areas in the CDCA have been reviewed to determine their eligibility for ACEC designation. The Turtle Mountain resources meet the ACEC criteria of relevance and importance, and the resources and values require special attention.

\section{Implementation Needs}

Prepare an ACEC management plan which would incorporate management actions already established for the Mopah Springs ACEC and includes the following measures:

* Maintain the vehicle closure by periodic ranger patrol and BLM staff observations.

* Continue to enforce and monitor the road closure into the Mopah Springs ACEC, as directed by the ACEC Plan (1982).

* Maintain the four-wheel drive Turtle Mountain Road which forms the northern boundary of the proposed ACEC. This route is part of the East Mojave Heritage Trail and would be maintained for this purpose.

* Education of trail users on desert etiquette and desert tortoise protection.

* Protect the area in accordance with the IMP until Congress decides on wilderness designation. 


\section{Turtle Mountain NNL/ACEC}

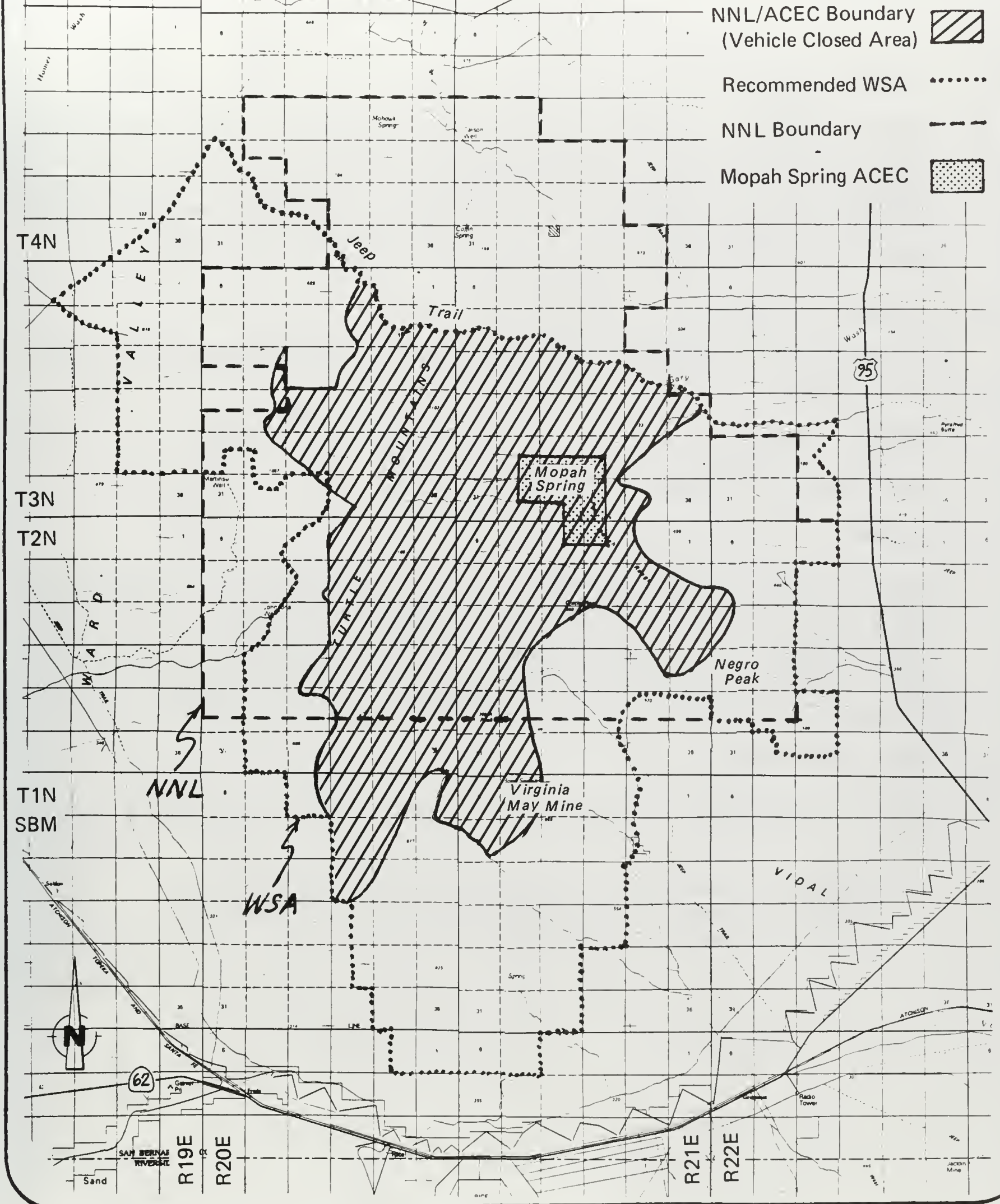




\section{AMENDMENT TWELVE \\ DESERT LILY PRESERVE ACEC}

\section{Proposed Amendment}

Designate the 2,040 acre Desert Lily Preserve Natural Area an ACEC. A preserve was dedicated in 1968. The area is valued for its outstanding floral displays when winter rains are plentiful. Management of the ACEC would continue the 1972 withdrawal from all forms of appropriation including mineral entry, and maintain the 1975 fence on the east side of the preserve which borders Highway 177. Additional management actions would be prescribed as necessary to protect the unique resources at this location.

\section{Other Alternatives Considered}

No Action: Continue to management area under multiple-use class " $\mathrm{L}$ " and maintain existing fencing and withdrawal.

\section{Decision}

Adopt Proposed Amendment.

\section{Rationale}

Prior to the passage of FLPMA, the Bureau of Land Management used a variety of designations to identify areas with unique or outstanding values. To eliminate the proliferation of terms, California BLM developed the ACEC "umbrella" concept, under which all special areas will be designated as ACECs. Special areas in the CDCA have been reviewed to determine their eligibility for ACEC designation. The resources found in the Desert Lily Preserve meet the ACEC criteria of relevance and importance, and the resources and values warrant special management attention.

\section{Implementation Needs}

Prepare ACEC management plan which would, at a minimum, include the following management actions:

* Maintain withdrawal from all forms of appropriation including mineral entry.

* Maintain the fence on the east side of the preserve bordering highway 177.

* Monitor the status of the unique resources at this location. 


\section{AMENDMENT THIRTEEN \\ NORTH ALGODONES DUNES NNL/ACEC}

\section{Proposed Amendment}

Designate ACEC status for the 27,767 acre portion of the Imperial Dunes to be called the North Algodones Dunes and which has the same boundaries as the portion of Wilderness Study Area CDCA-360 that the Bureau recommends as suitable for wilderness designation. The area is bordered on the south by Highway 78, on the west by the new Coachella Canal, on the east by the Southern Pacific Railroad and the Niland Glamis Road, and on the north by Mammoth Wash. The ACEC would be termed the North Algodones Dunes to distinguish it from the larger area known as the Imperial Sand Dunes. The ACEC will be managed in accordance with the 1987 Imperial Sand Dunes Recreation Area Management Plan (RAMP) which prescribed special management measures for protecting the northern portion of the dune system included in this ACEC.

\section{Other Alternatives Considered}

No Action: Continue management under the Imperial Dunes Recreation Area Management Plan (1987) and the Interim Management Policy for Lands Under Wilderness Review.

\section{Decision}

Adopt Proposed Amendment.

\section{Rationale}

Prior to the passage of FLPMA, the Bureau of Land Management used a variety of designations to identify areas with unique or outstanding values. To eliminate the proliferation of terms, California BLM developed the ACEC "umbrella" concept, under which all special areas will be designated as ACECs. Special areas in the CDCA have been reviewed to determine their eligibility for ACEC designation. The outstanding dune system and associated resources located in the North Algodones Dunes meet the ACEC criteria of relevance and importance, and warrant special management attention.

\section{Implementation Needs}

Implement the management actions prescribed in the Imperial Sand Dunes RAMP as follows:

* Maintain and aggressively enforce motor vehicle closure.

* Enhance nonmotorized recreation opportunities.

* Protect wilderness suitability in accordance with BLM's Interim Management Policy for Lands Under Wilderness Review.

* Monitor and protect the integrity of plant and wildlife habitat. 


\section{North Algodones Dunes NNL/ACEC}

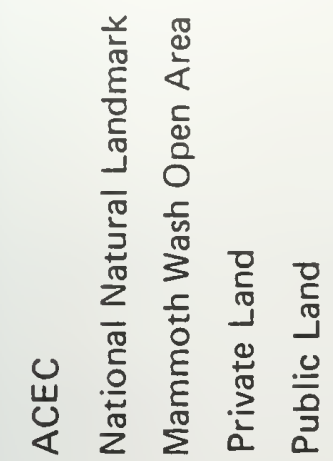

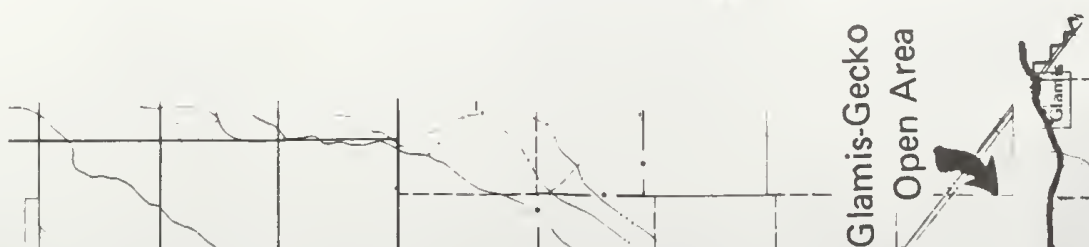

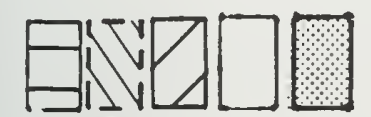
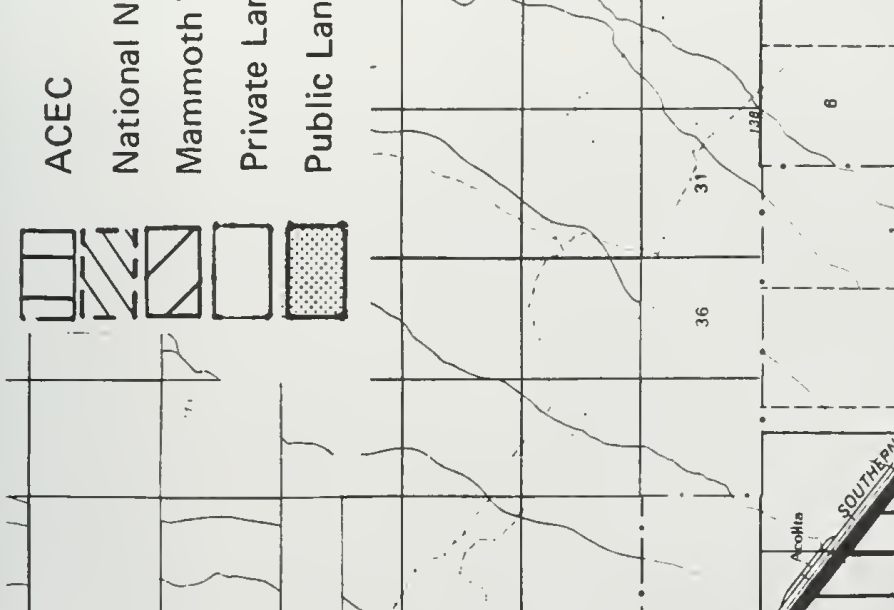


\section{AMENDMEN'T FOUR'TEEN \\ MULTIPLE-USE CLASS CHANGE IN PIPES CANYON}

\section{Proposed Amendment}

Change the multiple-use class of two parcels in the Pipes Canyon watershed (approximately 480 acres) from "L" to unclassified.

\section{Other Alternatives Considered}

No Action: Continue to manage the area under Multiple-Use class "L".

\section{Decision}

Adopt Proposed Amendment.

\section{Rationale}

The two parcels are isolated within an area containing only private lands or other scattered unclassified parcels. This change in classification would make these parcels available for sale or exchange and would be consistent with the long term management of this area.

\section{Implementation Needs}

None. 


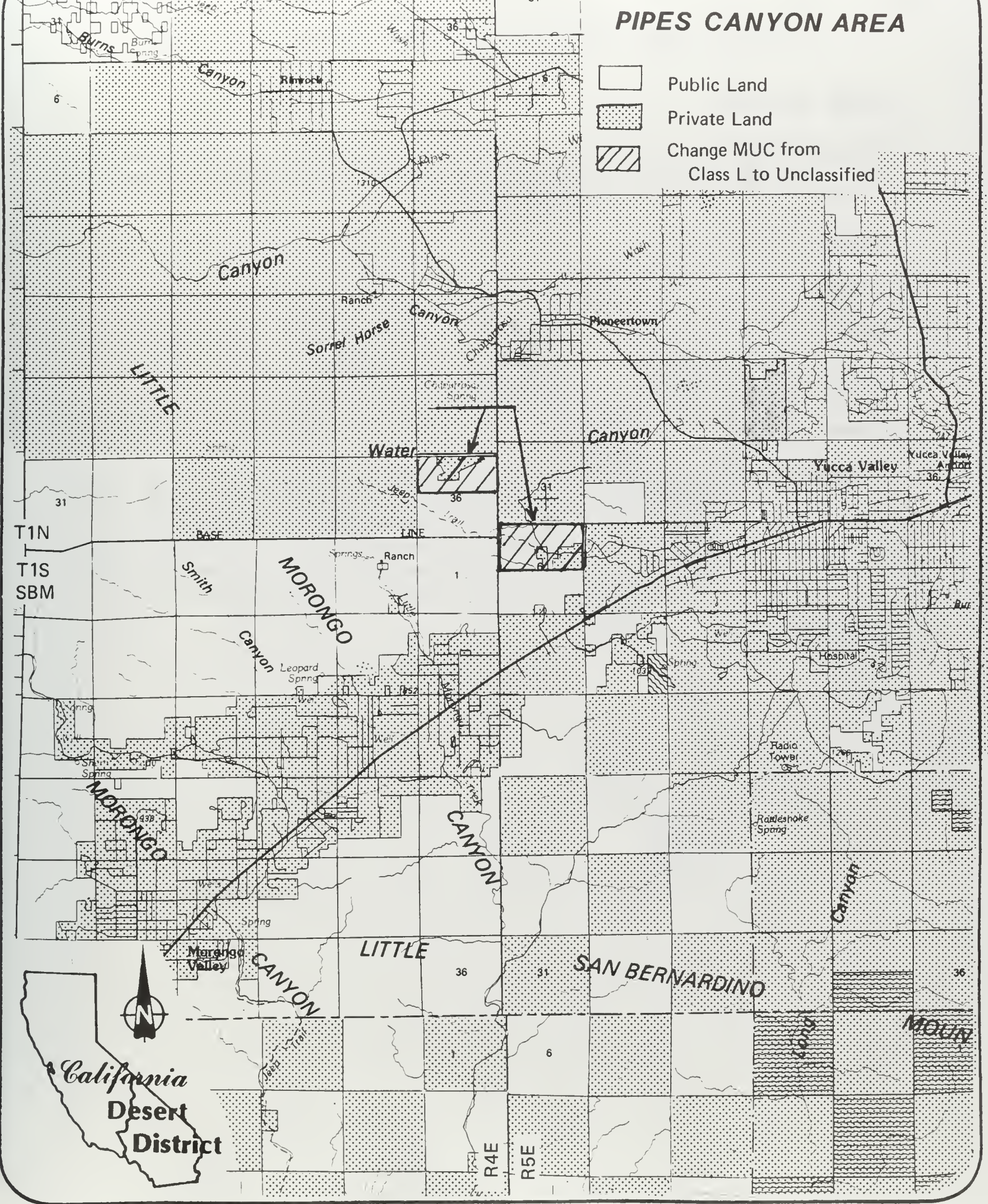




\section{AMENDMENT FIFTEEN \\ MULTIPLE-USE CLASS CIIANGE IN ARROYO SALADA OPEN AREA}

\section{Proposed Amendment}

Change the multiple-use class of approximately 8.5 sections in the Arroyo Salada Open Area from "I" to "M" for transfer to the State of California, and change two sections adjacent to the east of the open area from "I" to "M" for a total of 10.5 sections.

\section{Other Alternatives Considered}

No Action: Continue to manage the area under multiple-use class "I".

\section{Decision}

Adopt Proposed Amendment.

\section{Rationale}

The change in multiple-use designation from "I" to "M" will allow for the transfer of these lands to the California Department of Parks and Recreation which plans to add this area to their adjacent Ocotillo Wells State Vehicular Recreation Area. The area consists of scattered sections of private and public land. The State has acquired much of the private land and wants the authority to manage the remaining public land. Two sections just east of the State Parks acquisition area would be changed from Class "I" to Class "M" for consistency with the surrounding Class "M" lands.

\section{Implementation Needs}

None. 


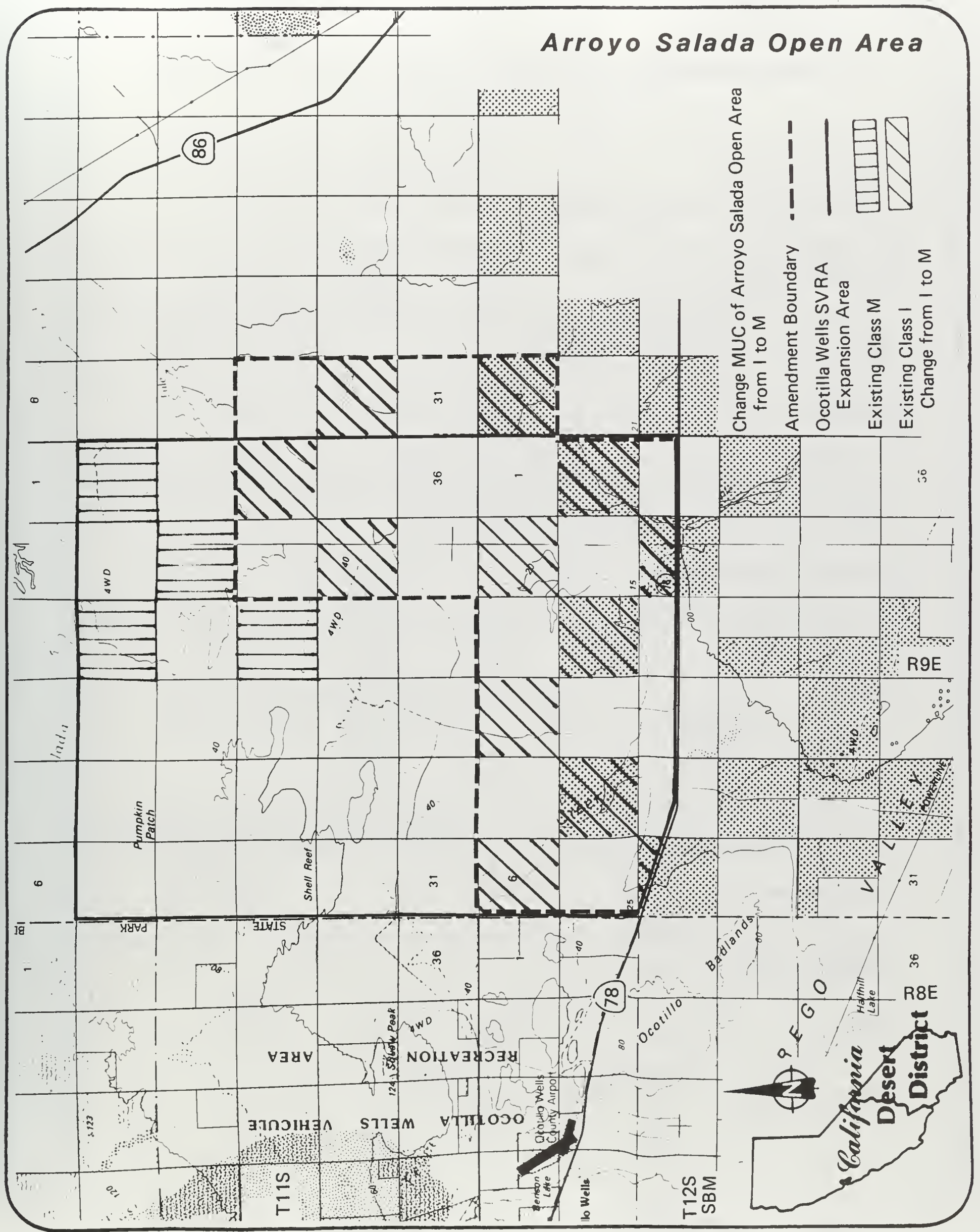




\section{AMENDMENT SIXTEEN \\ MULTIILE-USE CLASS CHANGE AND VEIHCLE ACCESS DESIGNATION \\ IN EL MIRAGE MANAGEMENT AREA}

\section{Proposed Amendment}

Within the El Mirage Cooperative Management Area:

(1) The multiple-use class of approximately 11,000 acres is changed from "unclassified" to Class "I" (intensive use).

(2) Motorized vehicle access is changed from "undesignated" to "open", except for 1,280 acres on the lake bed which are already classified as "open".

(3) As private land within the management area is acquired (approximately 12,000 acres), it will be designated as Multiple Use Class "I" and as an "open" motor vehicle access area.

(4) Outside the management area, 5,800 acres of scattered tracts of unclassified lands are changed to Class "M" with the intent of maintaining them. The remaining 3,200 acres of scattered tracts remain unclassified and available for disposal. Motorized vehicle access of these scattered lands are changed from "undesignated" to "limited."

\section{Other Alternatives Considered}

No Action: Continue to manage the area under the existing multiple-use classes and motor vehicle designations.

\section{Decision}

Adopt Proposed Amendment.

\section{Rationale}

The Proposed Amendment implements the 1990 management plan for El Mirage and provides the basis for resolving long-time conflicts over areas of mixed public and private land ownership.

\section{Implementation Needs}

Implement actions in accordance with the 1990 Management Plan for El Mirage Cooperative Management Area. 
|:

\section{EL MIRAGE \\ Cooperative Management Area}

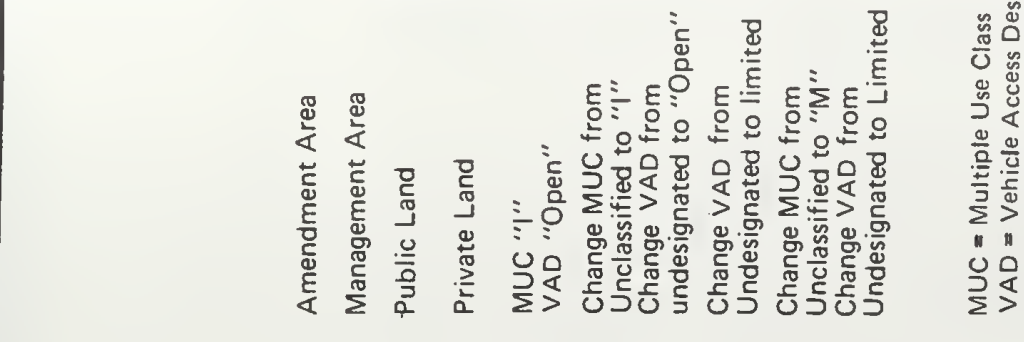

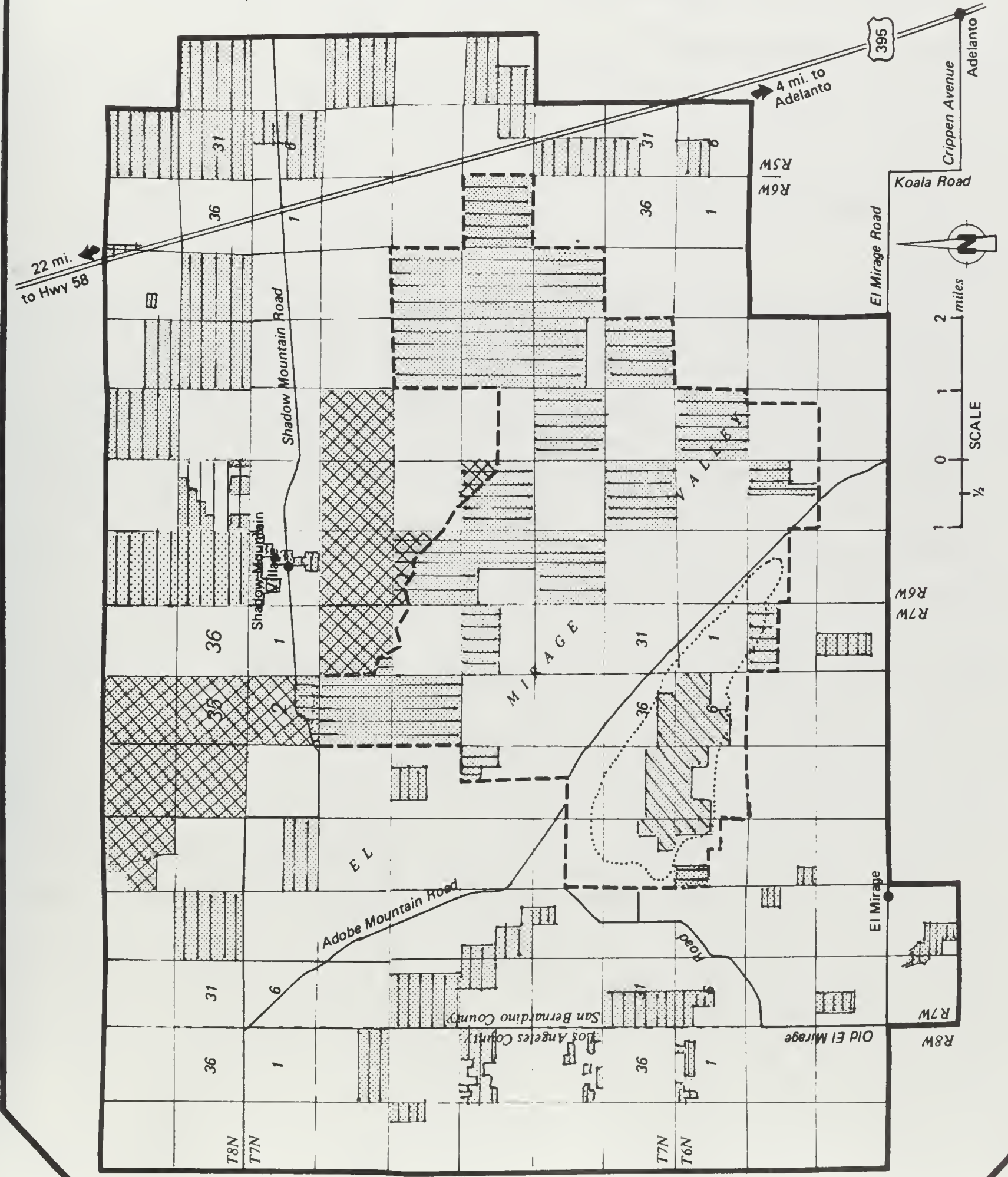


AMENDMENT SEVENTEEN

PALEN EPIIEMERAL GRAZING ALLOTMENT

\section{Proposed Amendment}

Delete the 50,500-acre Palen Grazing Allotment from the Livestock Grazing Element of the Califomia Desert Conservation Area Plan.

\section{Other Alternatives Considered}

No Action. The area would continue as an grazing allotment.

\section{Decision}

Adopt Proposed Amendment.

\section{Rationale}

The California Department of Fish and Game has expressed their intention of augmenting the bighorn sheep population in the Granite and Palen Mountain ranges adjacent to the Palen Grazing Allotment. Bighorn sheep likely would move through the allotment as they pass between the Coxcomb Mountains and the Palen and Granite Mountains. Recent studies have indicated that bighorn are highly susceptible to pathogenic organisms carried by domestic sheep. The deletion of this allotment would ensure that such a risk would be avoided. The allotment has not had authorized grazing use since completion of the CDCA Plan in 1980, and no interest has been demonstrated in the allotment.

\section{Implementation Needs}

None. 
AMENDMENT 17

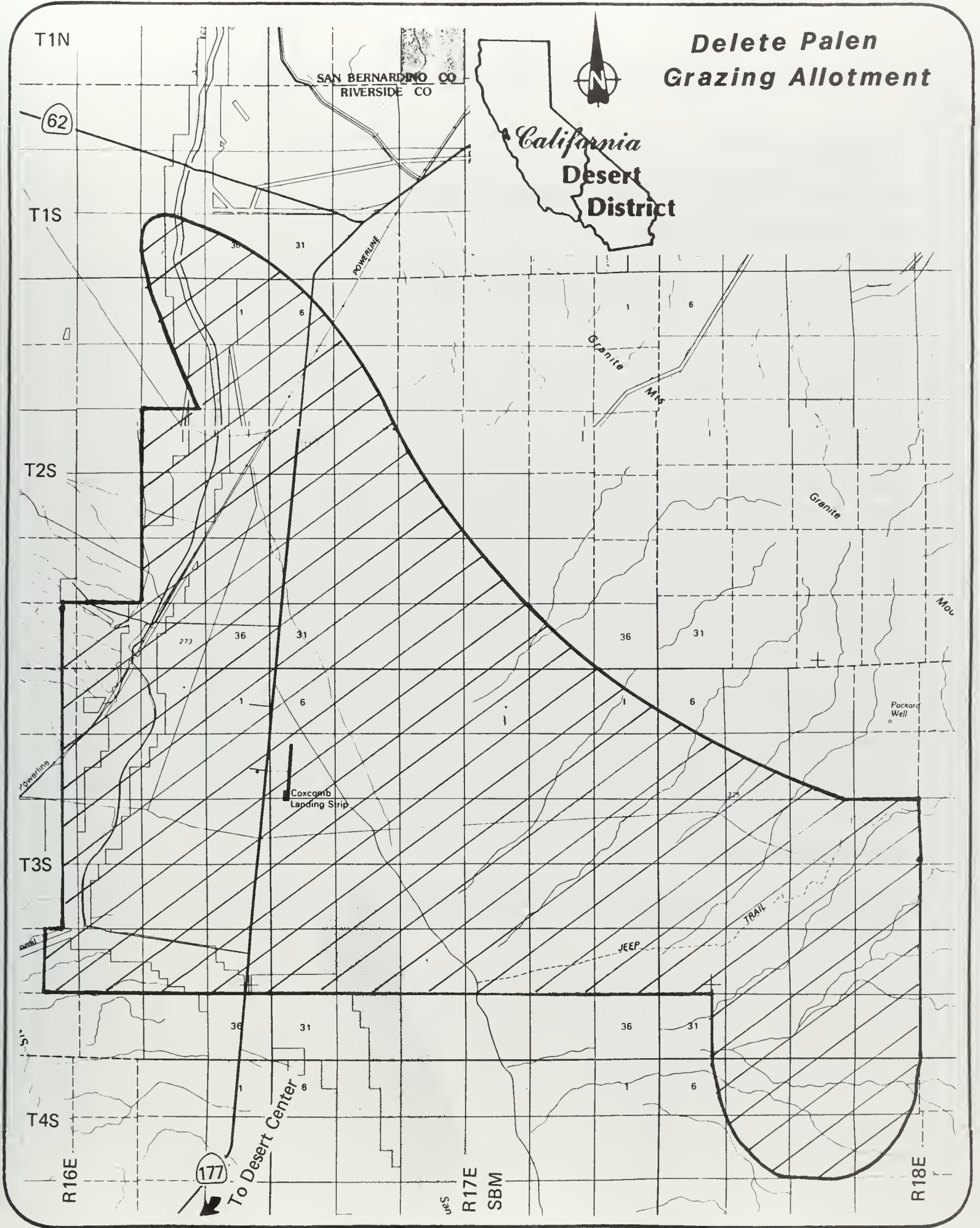




\section{AMENDMENT EIGHTEEN \\ RICE VALLEY EPIIEMERAL GRAZING ALLOTMENT}

\section{Proposed Amendment}

No Action: Continue the Rice Valley Ephemeral Grazing Allotment.

\section{Other Alternatives Considered}

Delete the 37,800-acre Rice Valley Ephemeral Grazing Allotment from the Livestock Grazing Element of the California Desert Conservation Area Plan.

\section{Decision}

Adopt the Proposed Amendment.

\section{Rationale}

This amendment proposal was introduced at the request of the California Department of Fish and Game which was considering the possibility of introducing bighorn sheep into the Big Maria and Little Maria Mountains in the vicinity of the Rice Valley Ephemeral Grazing Allotment. If introduced into these mountain ranges, bighorn sheep would likely move through the allotment as they pass between the Big and Little Marias and would be exposed to pathogenic organisms carried by domestic sheep. However, based in part on habitat factors, the Big Maria Mountains appear to be a deficiency zone (i.e., a portion of fragmented habitat which lacks crucial biological factors causing the area to be inadequate) for the bighorn sheep (Weaver, R.A. and Mensch, J.L.,1971, "Bighorn Sheep in Northwestern Riverside County", California Department of Fish and Game, Wildlife Management Administration Report No. 70-1). Further, the factor of domestic sheep being grazed on private land nine miles from the Big Maria Mountains would remain a concern even if Rice Valley Ephemeral Grazing Allotment were to be closed (Technical Staff Desert Bighorn Council, 1990, "Guidelines for management of domestic sheep in the vicinity of desert bighorn habitat", Desert Bighorn Council Trans., Vol. 34). For these reasons, the introduction of bighorn seems problematic in the near future and the need to delete the grazing allotment unnecessary at this time.

\section{Implementation Needs}

Reconsider the issue during environmental assessment process, if a renewal application for the lease, which expires in 1994, is filed. 


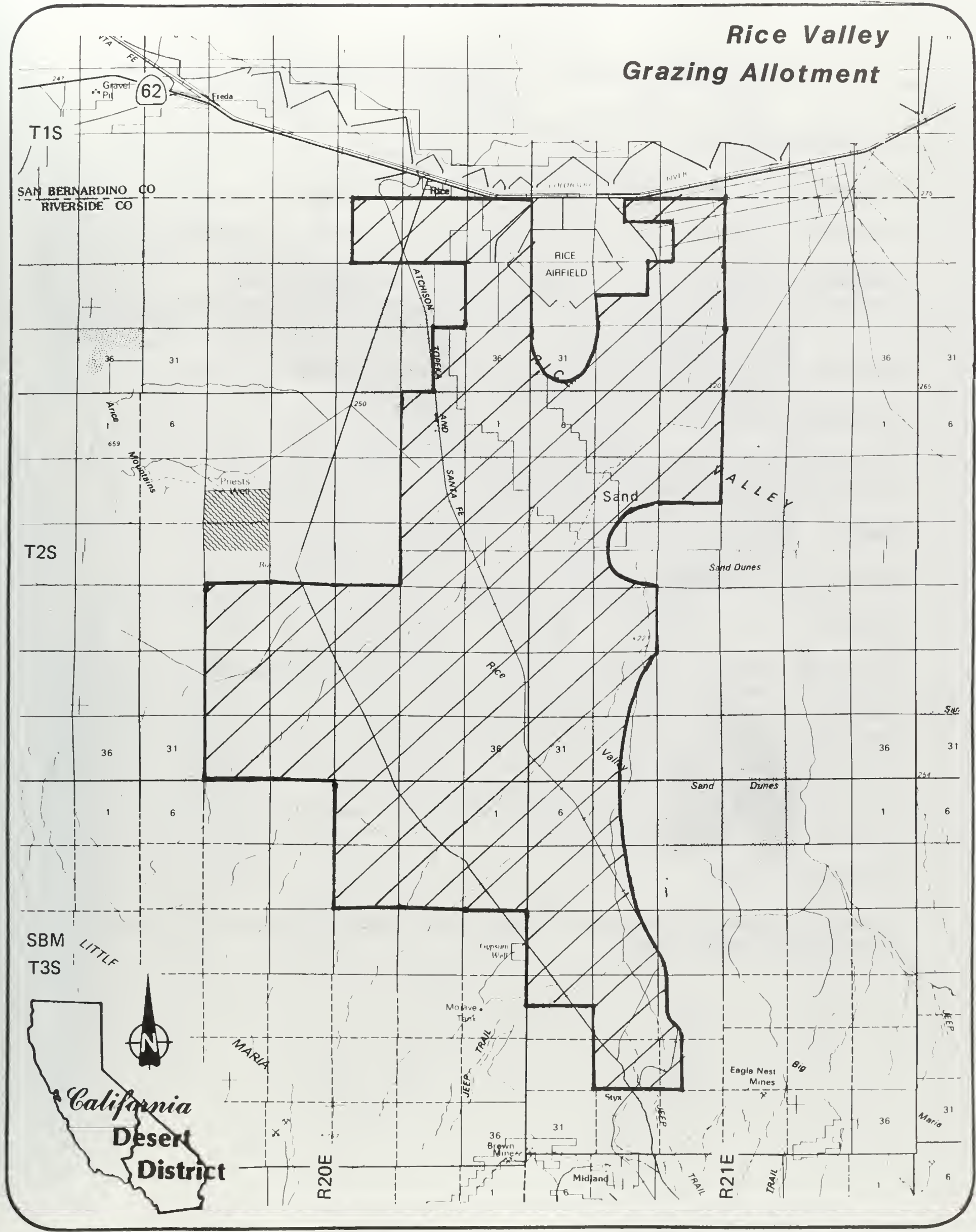




\section{AMENDMENT NINETEEN \\ DELINEATION OF DESERT TORTOISE MANAGEMENT CATEGORIES}

\section{Proposed Amendment}

Delineate tortoise habitat on public land in the CDCA in three management categories as follows:

Category I - 2,227,000 acres

Category II - 461,000 acres

Category III - 1,529,000 acres
Goal: Maintain stable, viable populations and increase populations where possible.

Goal: Maintain stable, viable populations.

Goal: Limit declines to the extent possible using mitigation measures.

The "crucial habitat" as shown on Map 4 of the CDCA Plan is superseded by this amendment.

\section{Other Alternatives Considered}

No Action: Continue utilization of the single category of crucial habitat as defined in the California Desert Conservation Area Plan.

\section{Decision}

Adopt Proposed Amendment.

\section{Rationale}

The BLM was directed to categorize tortoise habitat in three categories in the Desert Tortoise Habitat Management on the Public Land: A Rangewide Plan (1988). Goals and criteria were established for each management category and applied, utilizing the best available data, to the California Desert Conservation Area Plan. The proposed amendment establishes the categories and their boundaries but does not impose management constraints for the different categories. Categories are assigned to public land only and not to intermingled private land or State land. The delineation of habitat in the categories is to provide emphasis and visibility and to assist in the analysis and review of proposed actions in desert tortoise habitat.

\section{Implementation Needs}

Any activity on public land that requires an authorization will require consultation with the United States Fish and Wildlife Service. 
Amendment 19

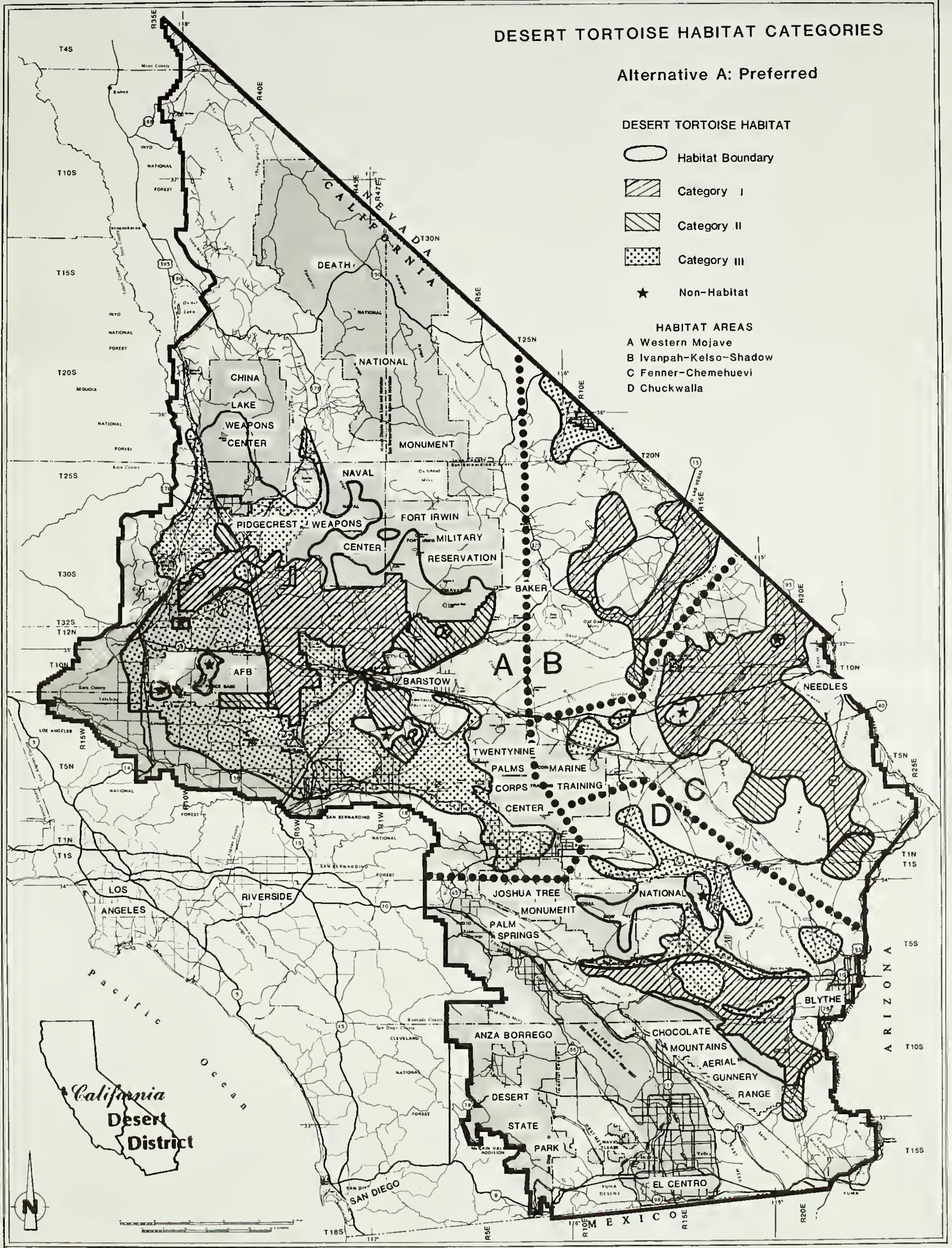

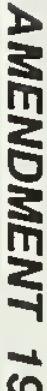




\section{Comments \& Responses}




\title{
WRITTEN COMMENTS AND RESPONSES
}

During the 60 day public review period, October 18 to December 16, 1991, a total of 16 letters addressing the proposed amendments were received by the BLM. All letters were reviewed. Those letters that had substantive comments and had a direct bearing on a proposed amendment were given a response. Table 1 lists each comment letter by author and in approximate order of receipt. Each letter has been designated a reference number. Within a letter substantive comments are noted using the reference number, and the response is keyed to the comment. All comment letters have been reprinted verbatim and substantive comments addressed. Letters that did not address substantive issues but presented an opinion are acknowledged by their inclusion.

\section{TABLE 1}

Written Comments

\author{
Letter \\ Number \\ Source of Letter \\ 1 \\ 2 \\ 3 \\ 4 \\ 5 \\ 6 \\ 7 \\ 8 \\ 9 \\ 10 \\ Roy M. Evans, City of Victorville \\ Elden Hughes, Sierra Club SCNRCC \\ Tom Dodson, Desert Tortoise Preserve Committee \\ Harvey J. Sawyer, District 8, Department of Transportation \\ George E. Moncsko, Desert Tortoise Preserve Committee \\ Tom Levy, Coachella Valley Water District \\ John R. Swanson \\ Carol Whiteside, The Resources Agency of California \\ Mary Griggs, State Lands Commission \\ Steven Ault, California Integrated Waste Management Board \\ June Latting, Ph.D. \\ Dr. John T. Rotenberry, UCR Natural Reserve System; Dr. Phillippe S. Cohen, Granite \\ Mountains Reserve; Dr. F. Allan Muth, Boyd Deep Canyon Desert Research Center \\ Patrice Davison, Association of 4WD Clubs, Inc. \\ Ron Schiller, High Desert Multiple-Use Coalition \\ Kathleen M. Kunysz, The Metropolitan Water District \\ Thomas M. Cragg, Department of Army, Fort Irwin
}


letter 1
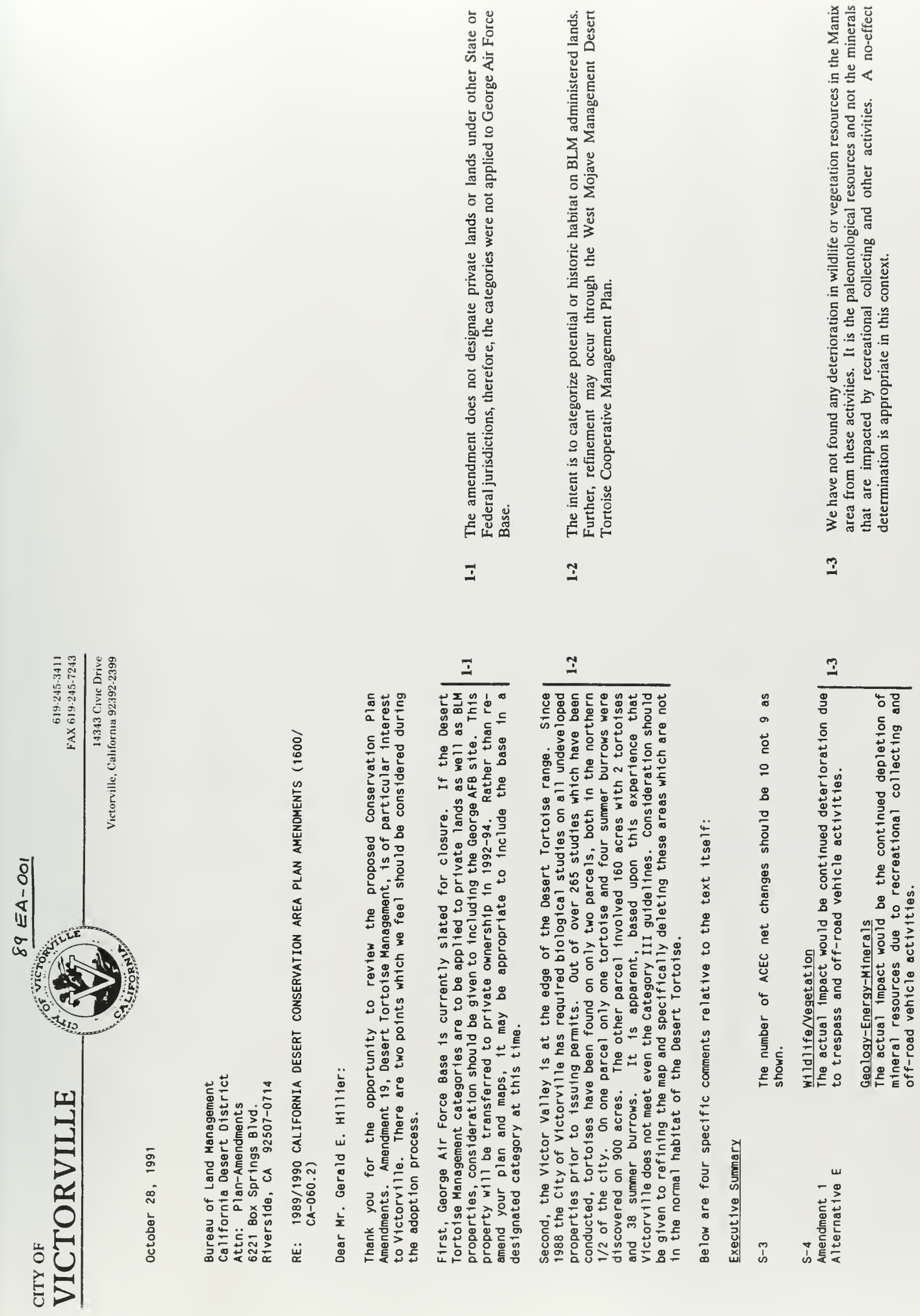

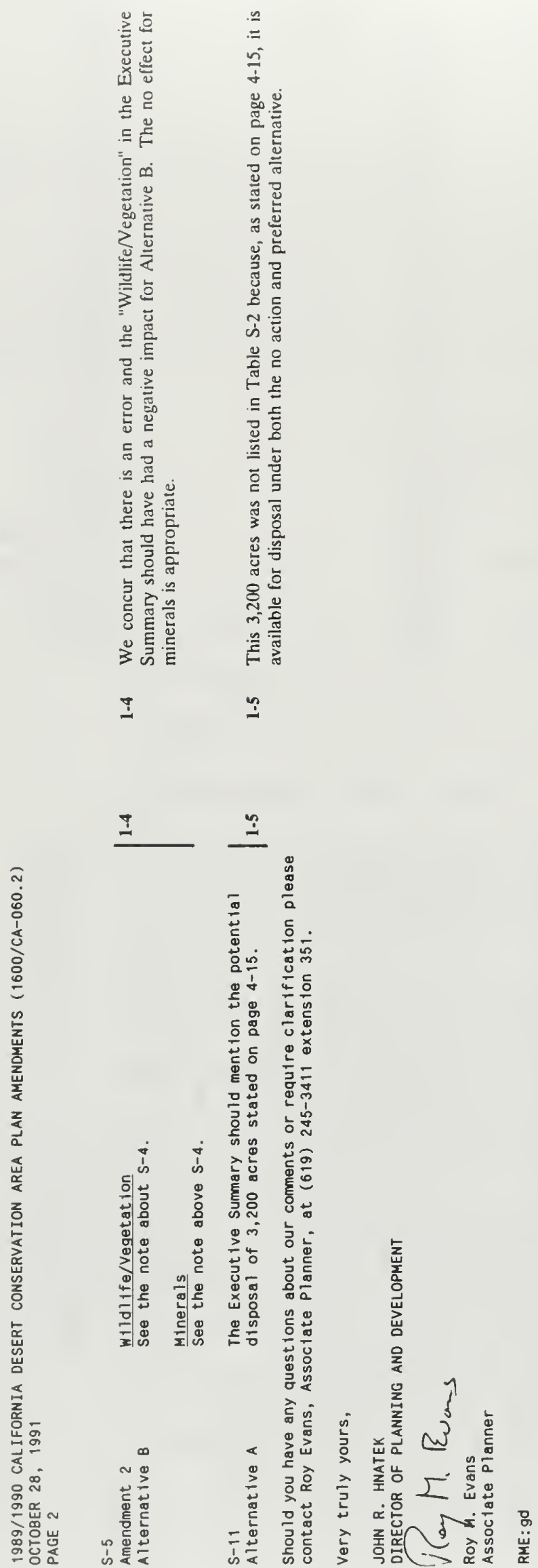
letter 2

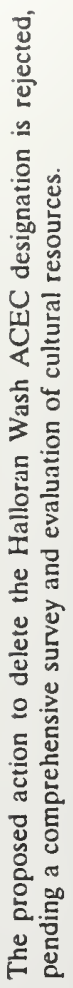

$\bar{i}$

r
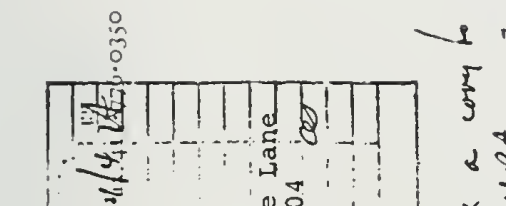

$\bar{i}$

i.

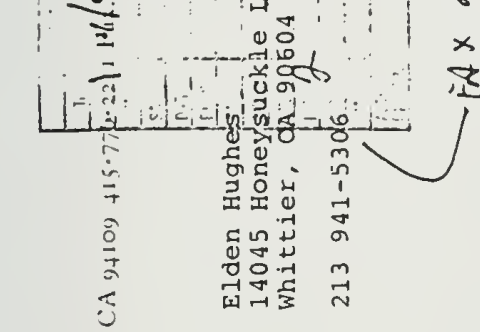

$2 \frac{2}{2}$

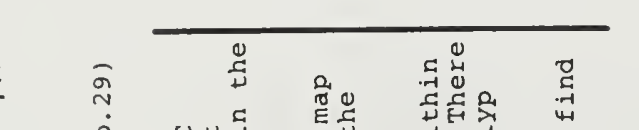

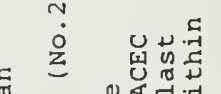

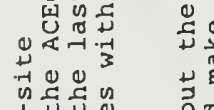

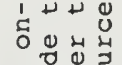

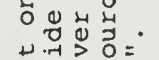

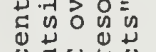

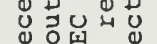

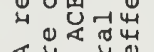

$\varangle$

= 蛅击品

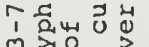

की

g

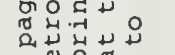

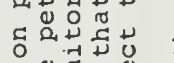

茨

(1)

จ

है.

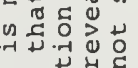

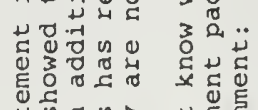

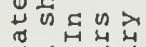

㟧 $匚 0$ \&

बत्में

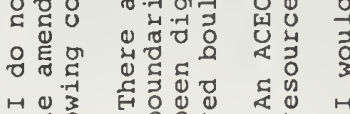

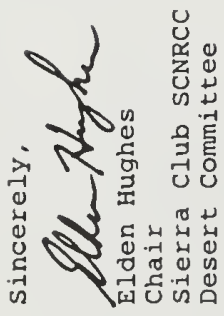

3.

40 है⿴囗十

म के द्ये

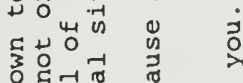

辛

जा वै०

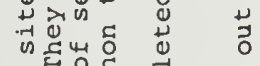

\& 0 व

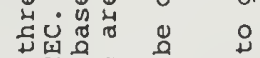

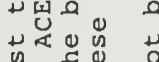

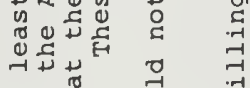

造

을

40 잉

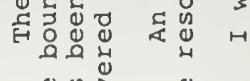

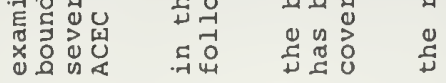


letter 3
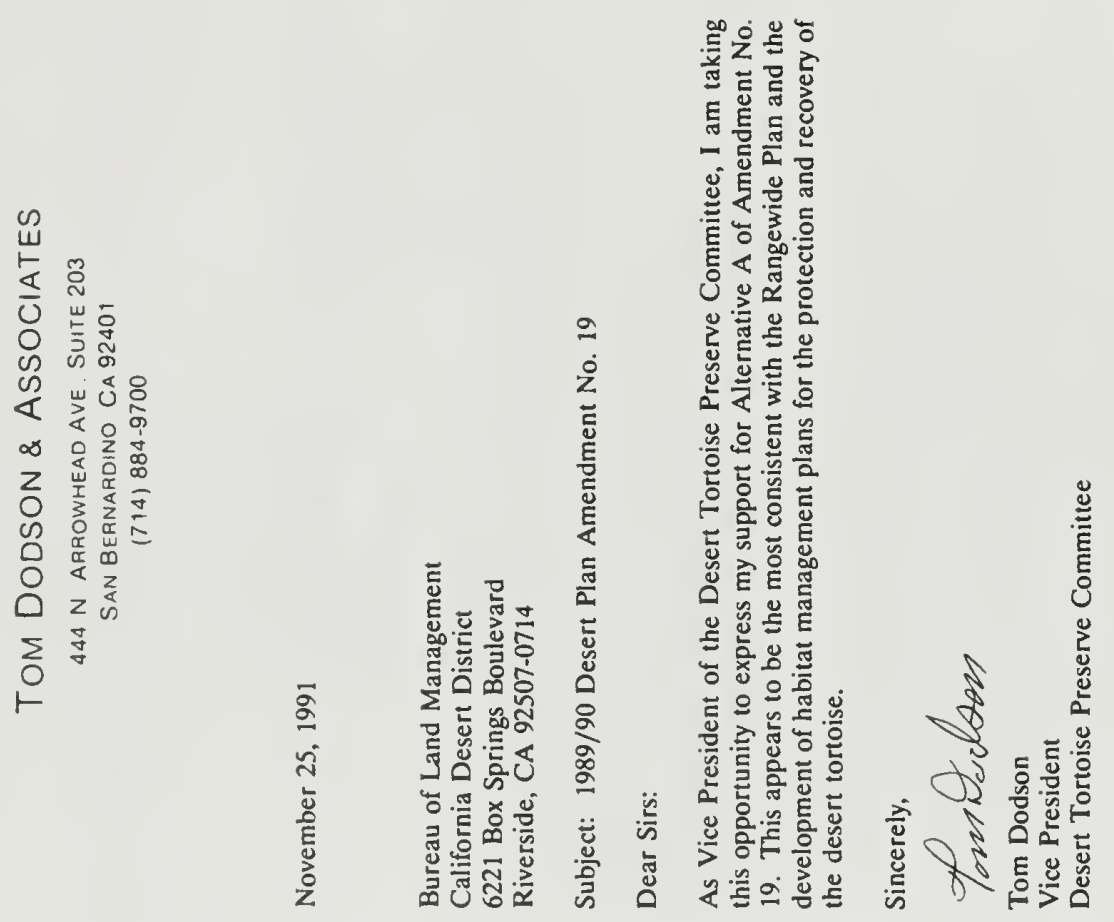


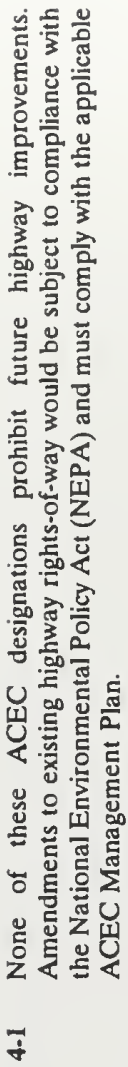

letter 4

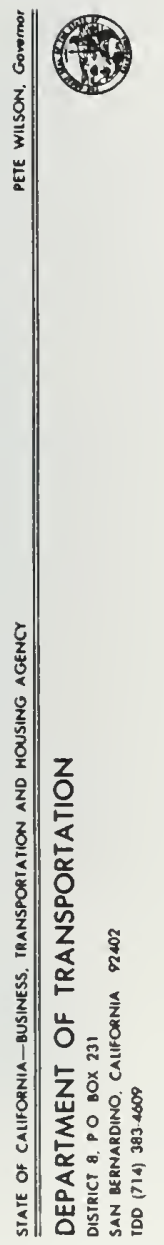

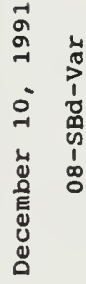
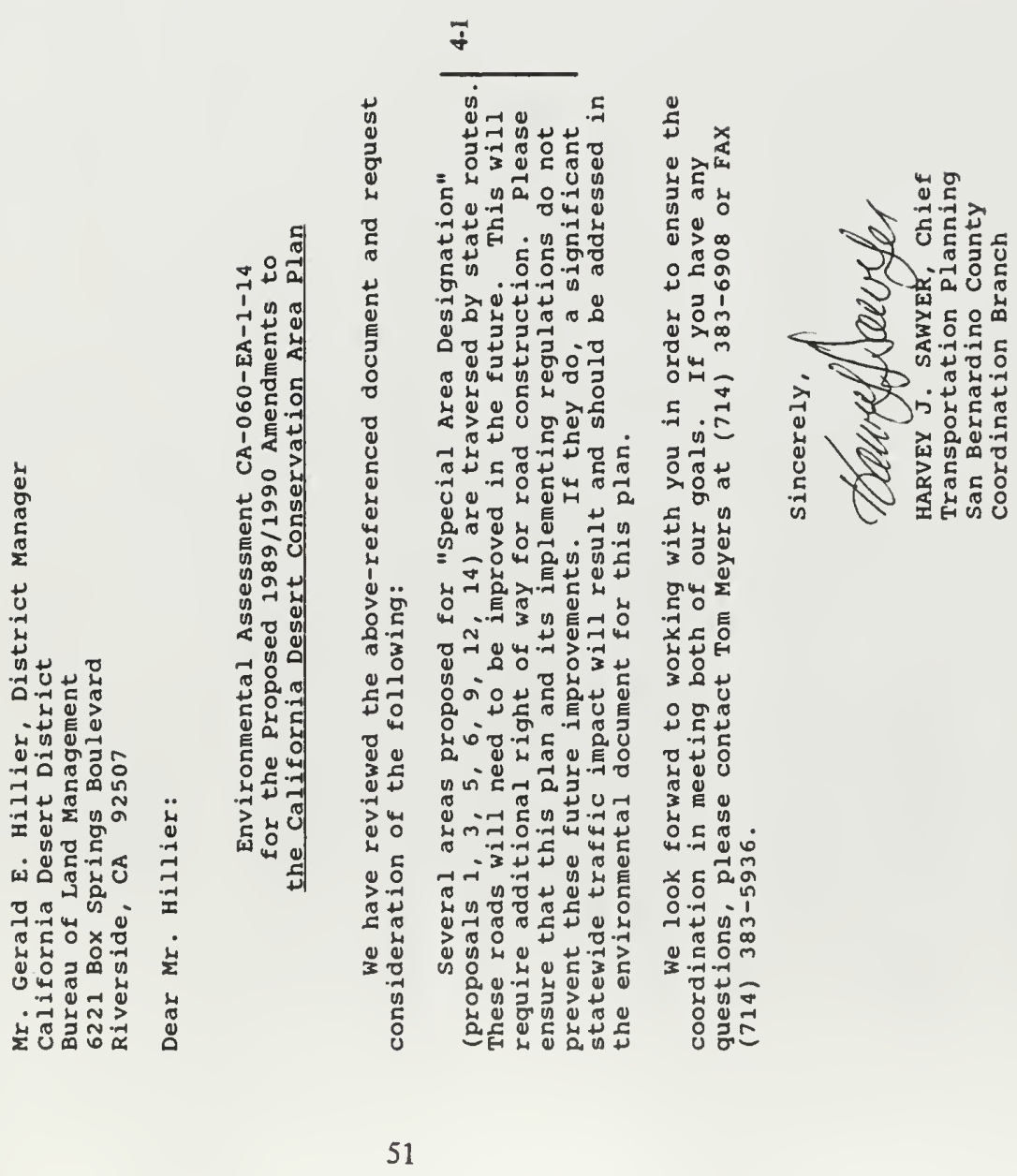
letter 5

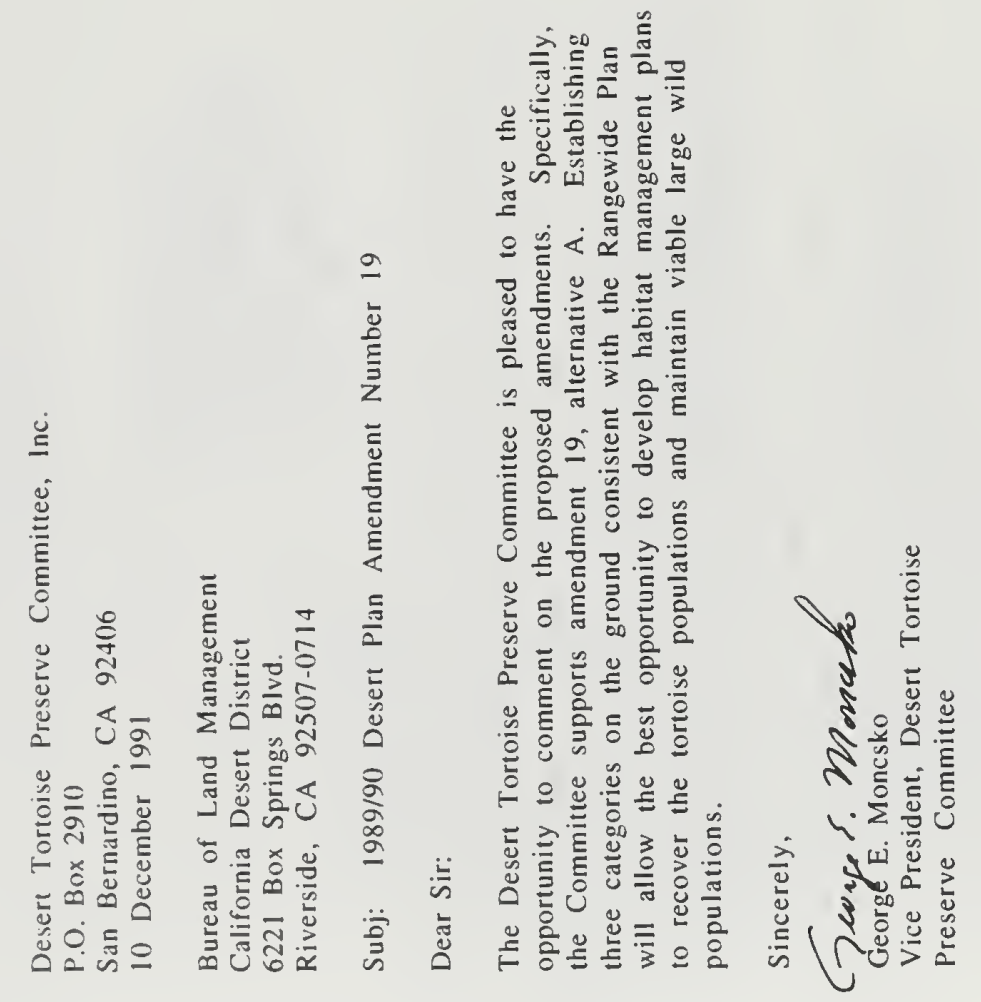


letter 6
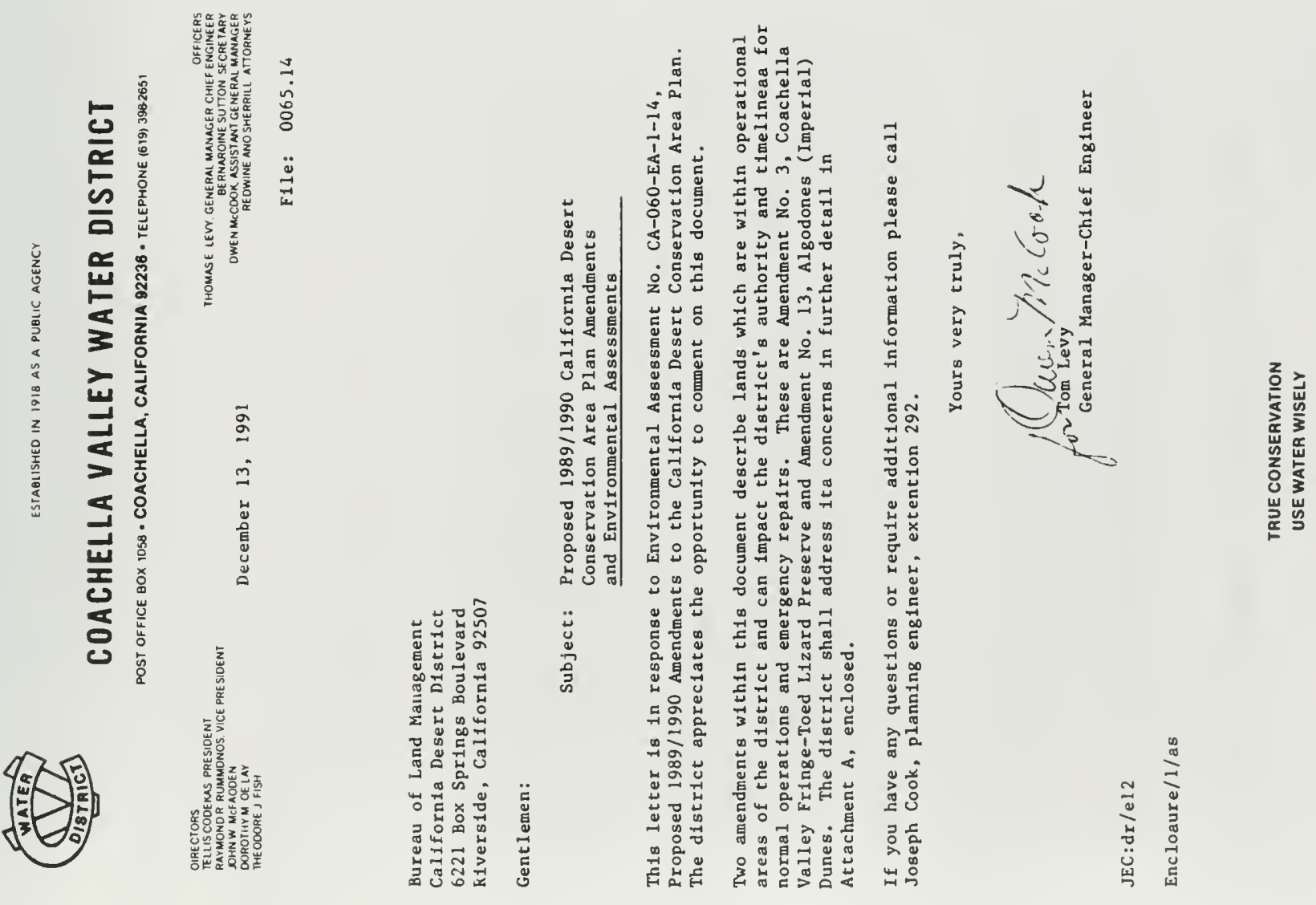

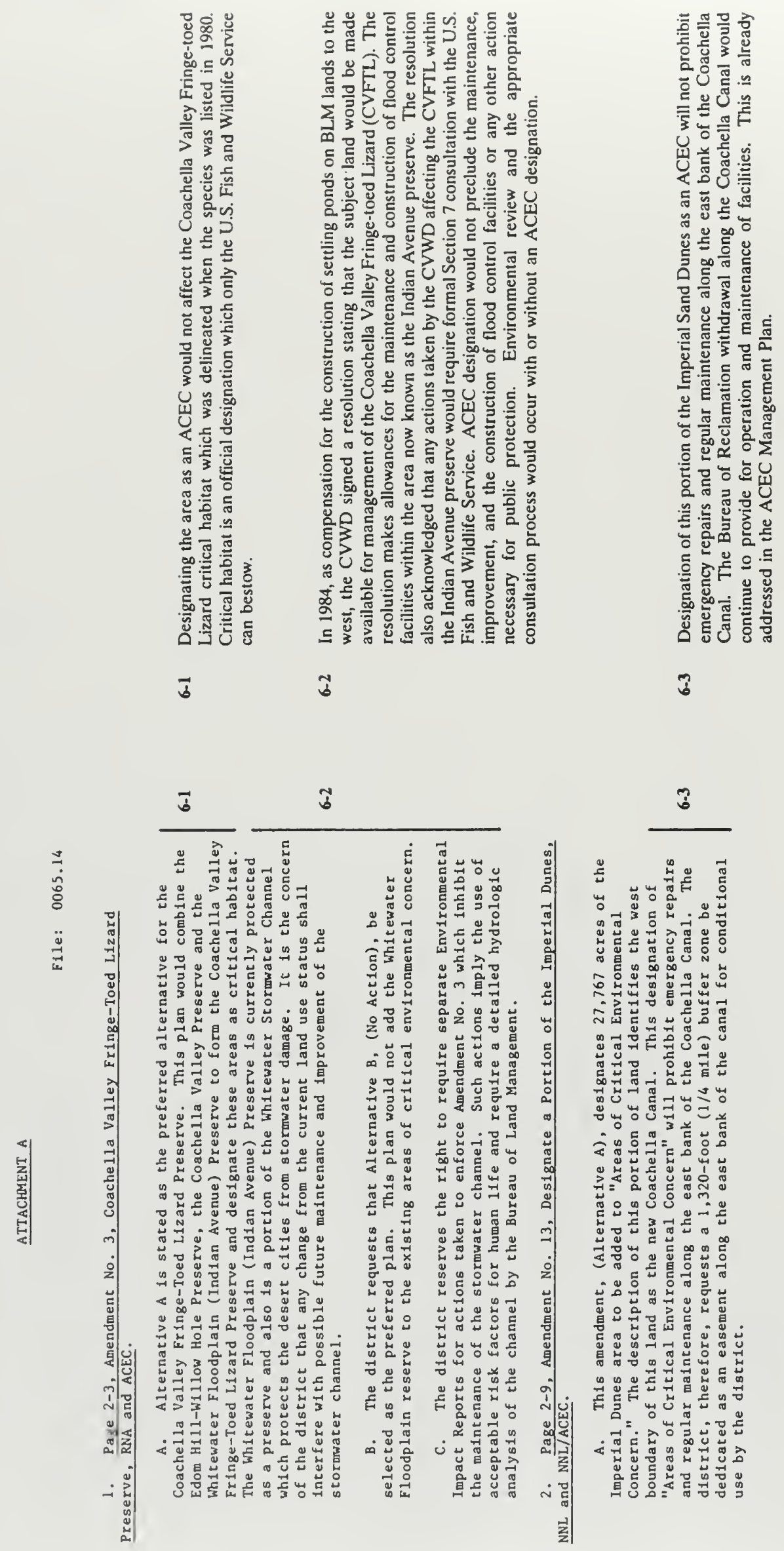
letter 7
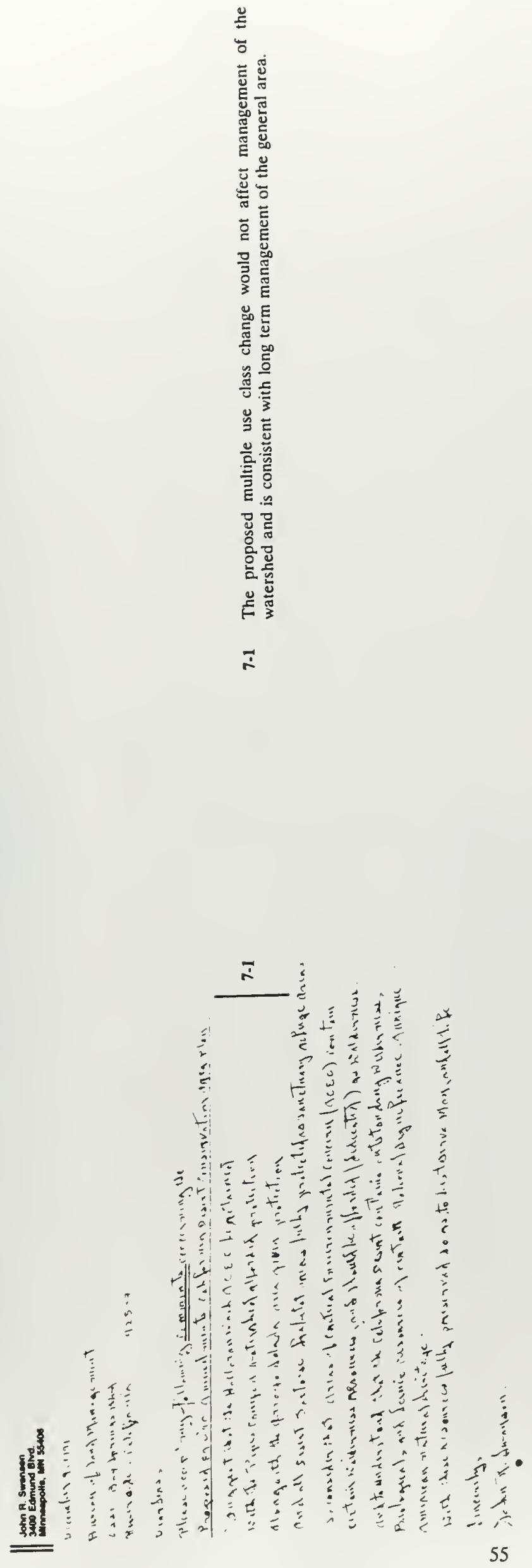


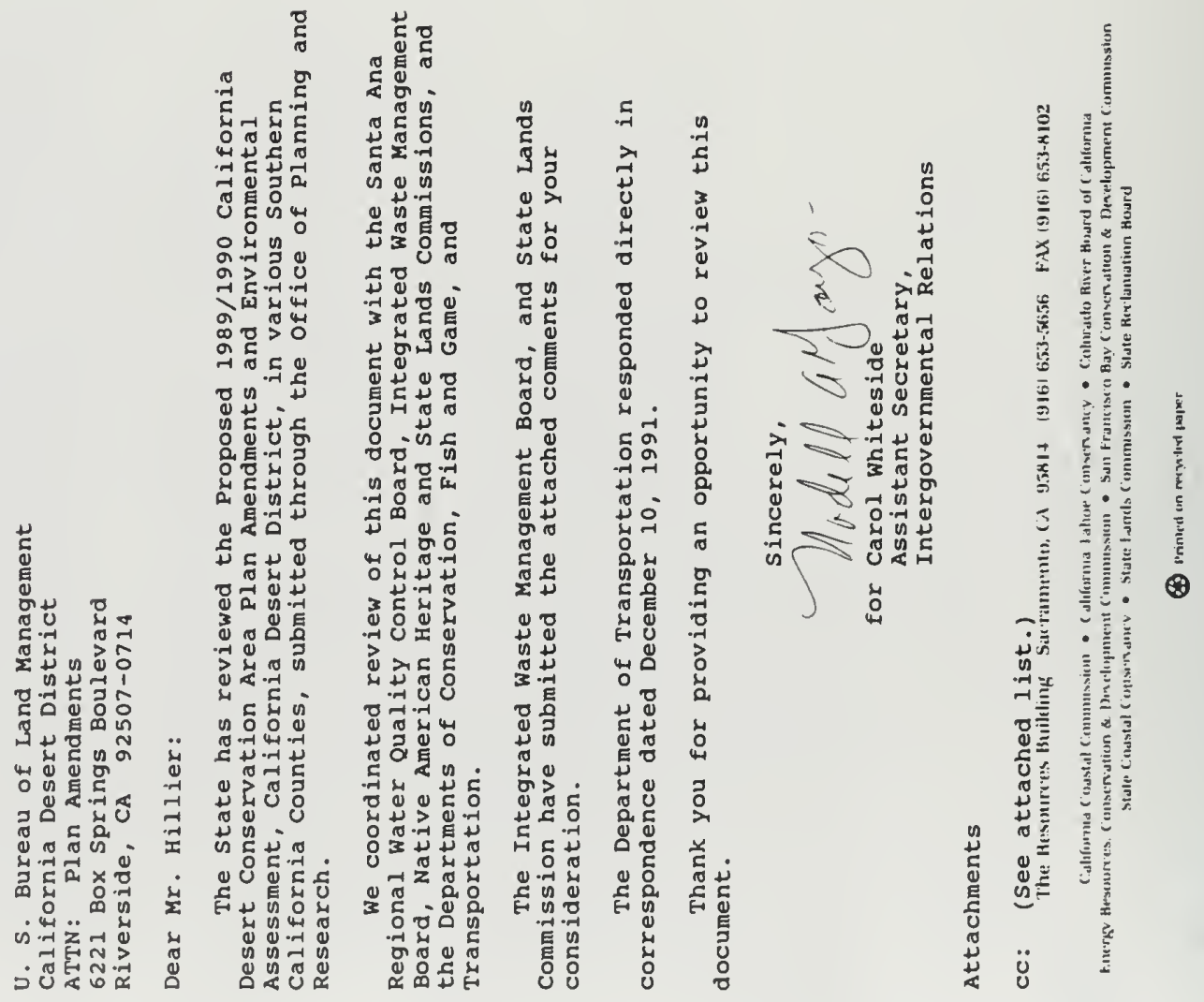




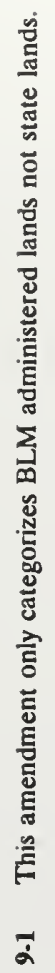
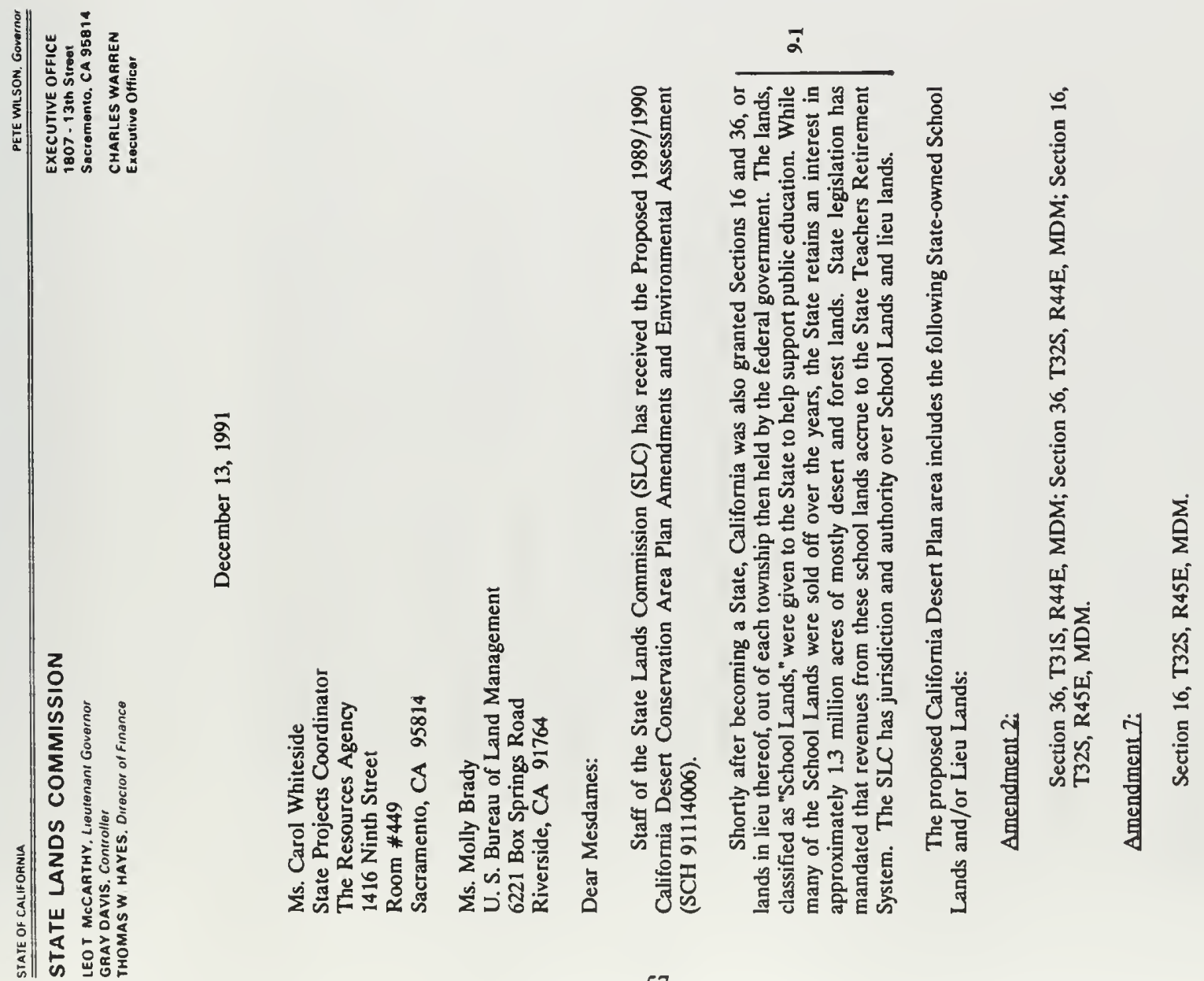


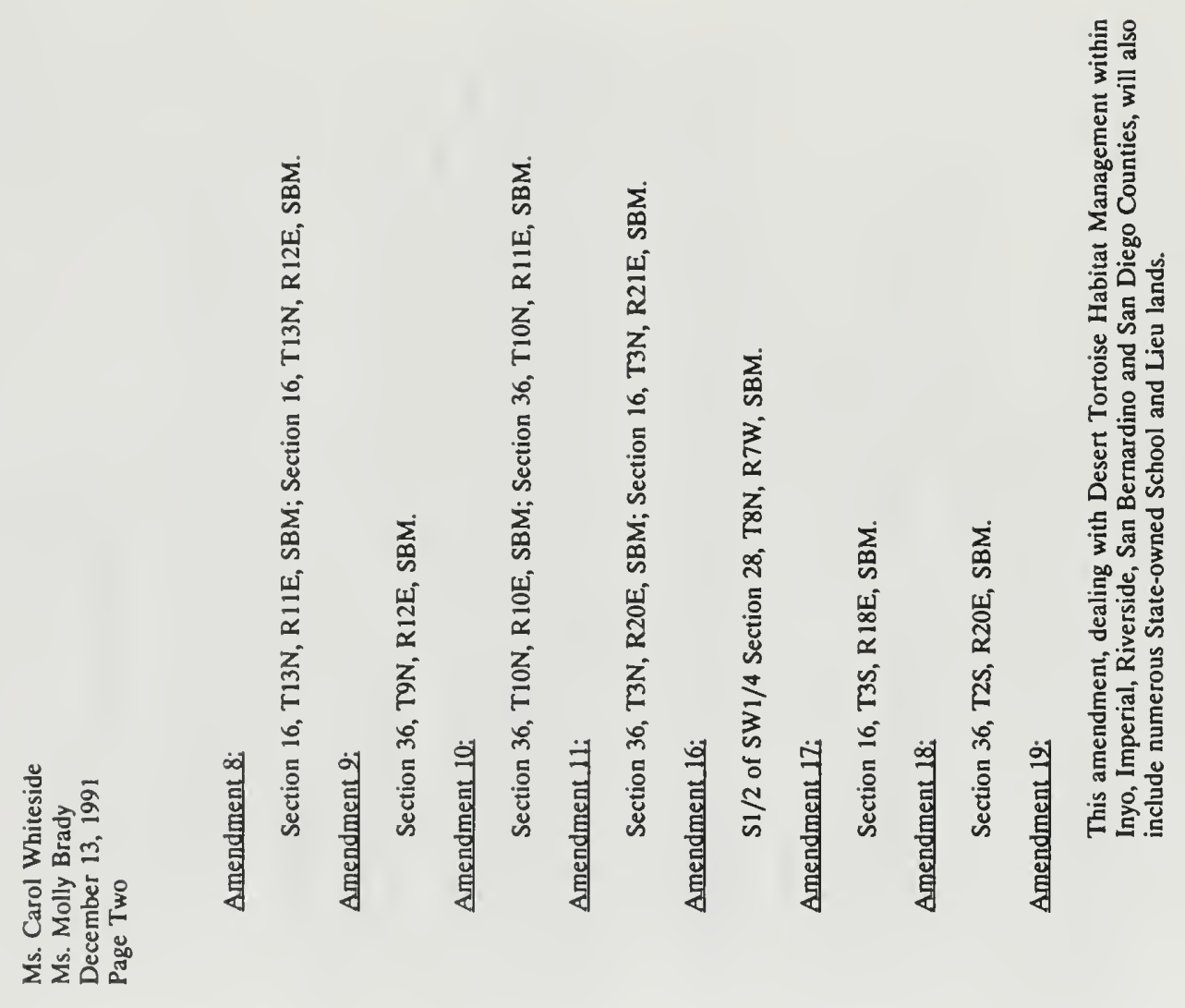




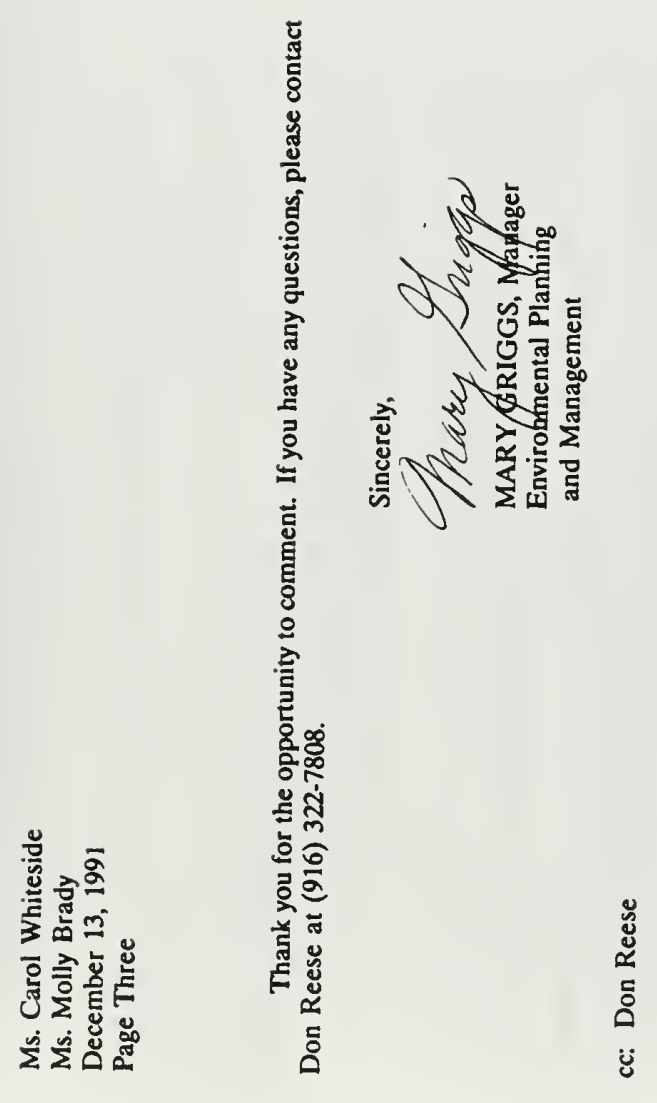


letter 10

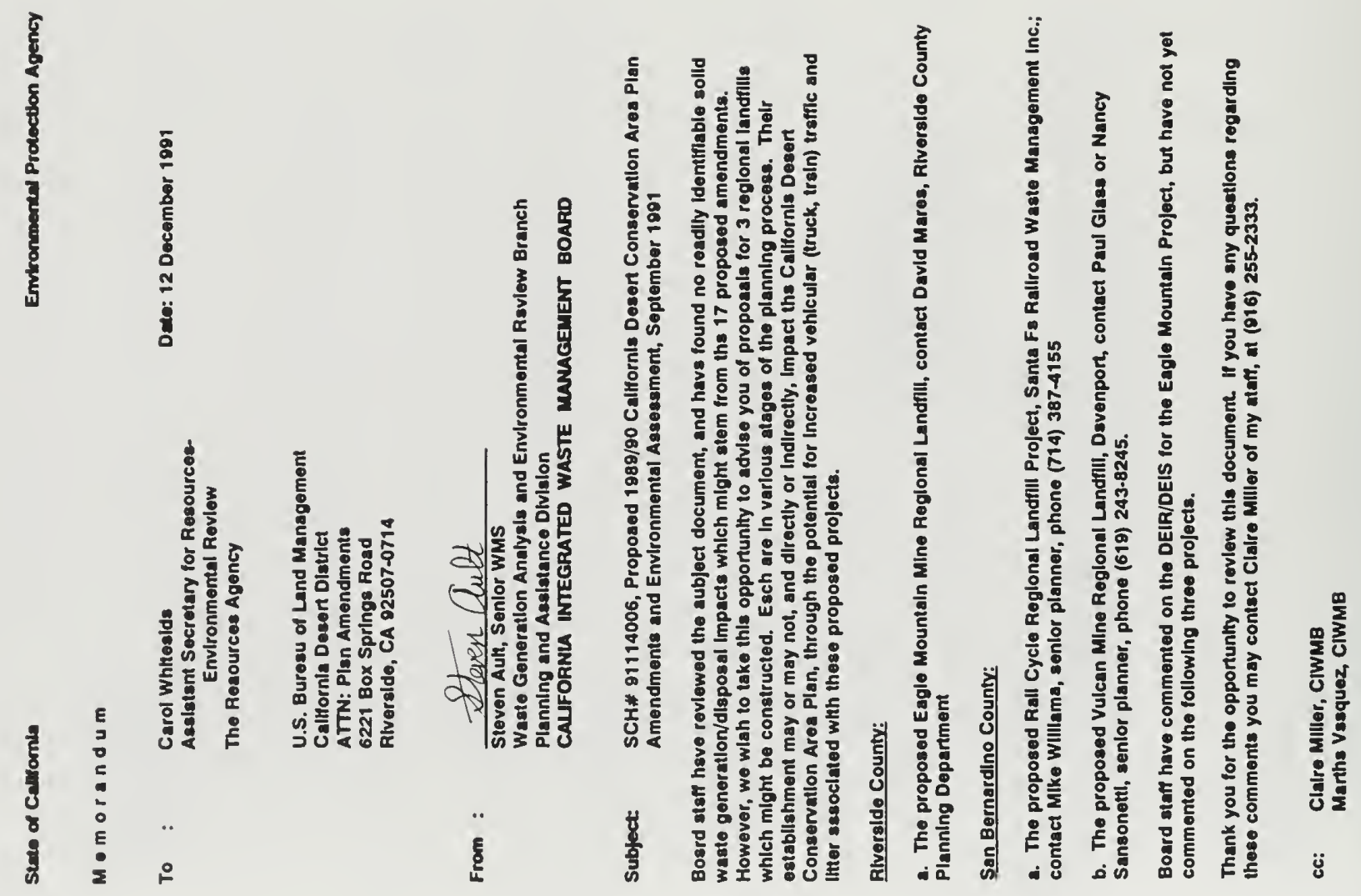



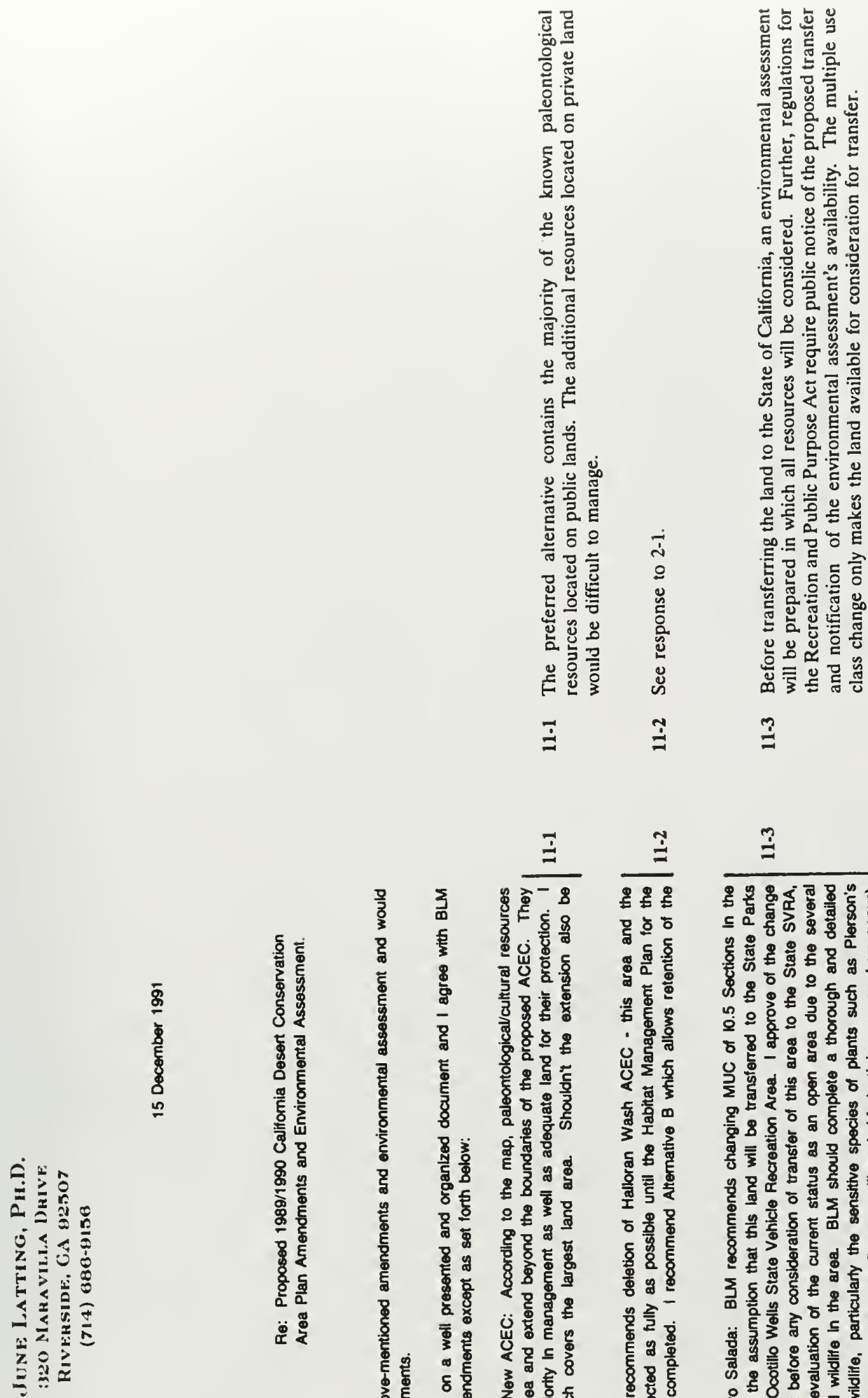

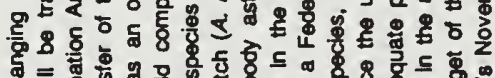

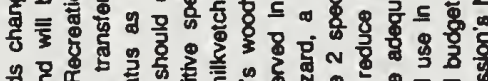

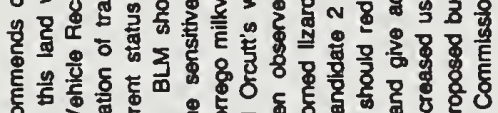

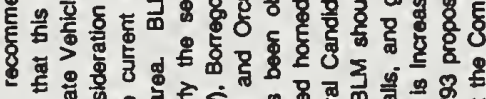

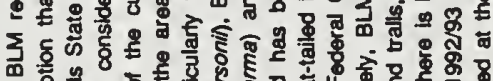

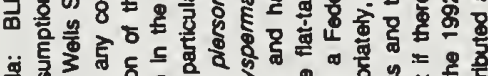

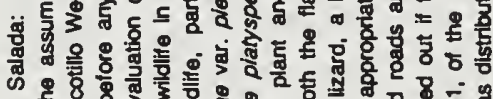
क

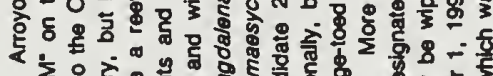

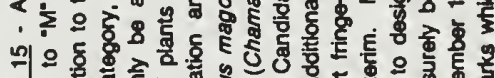

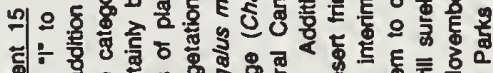

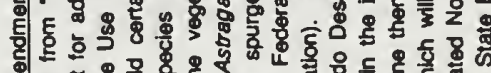

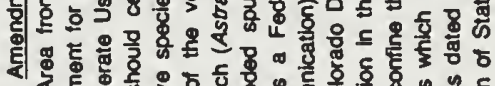

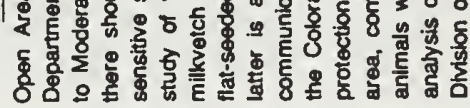



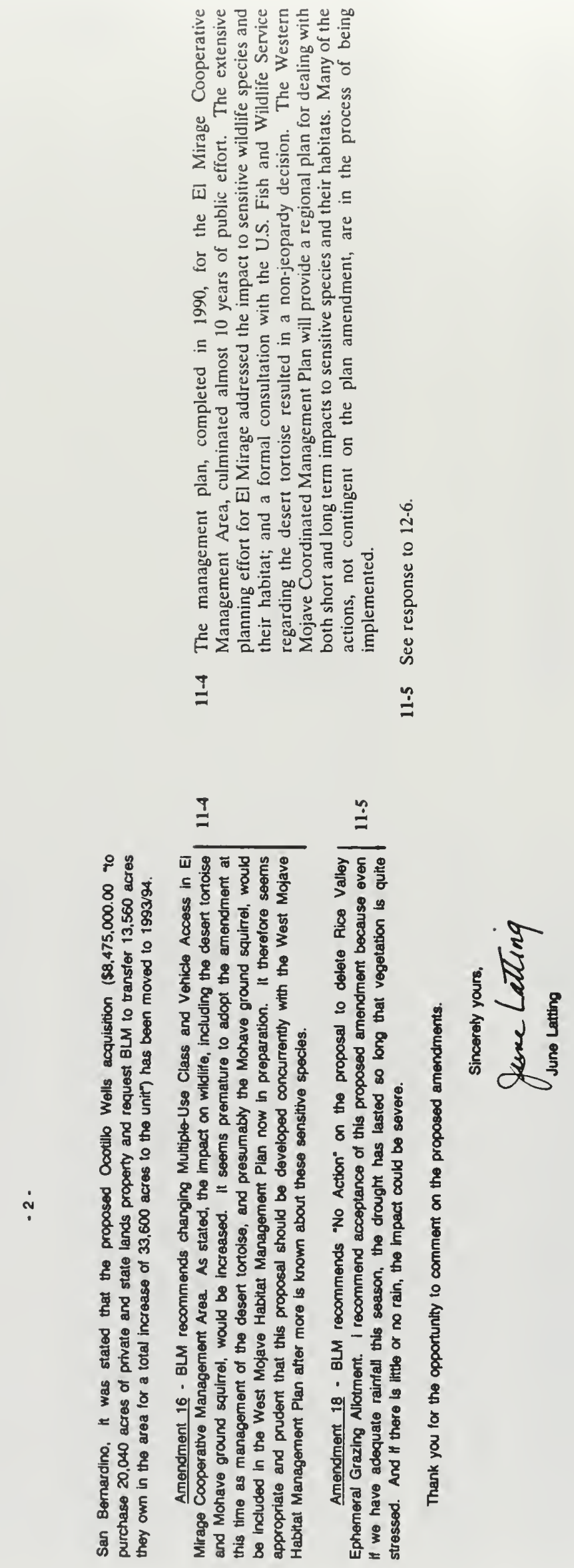

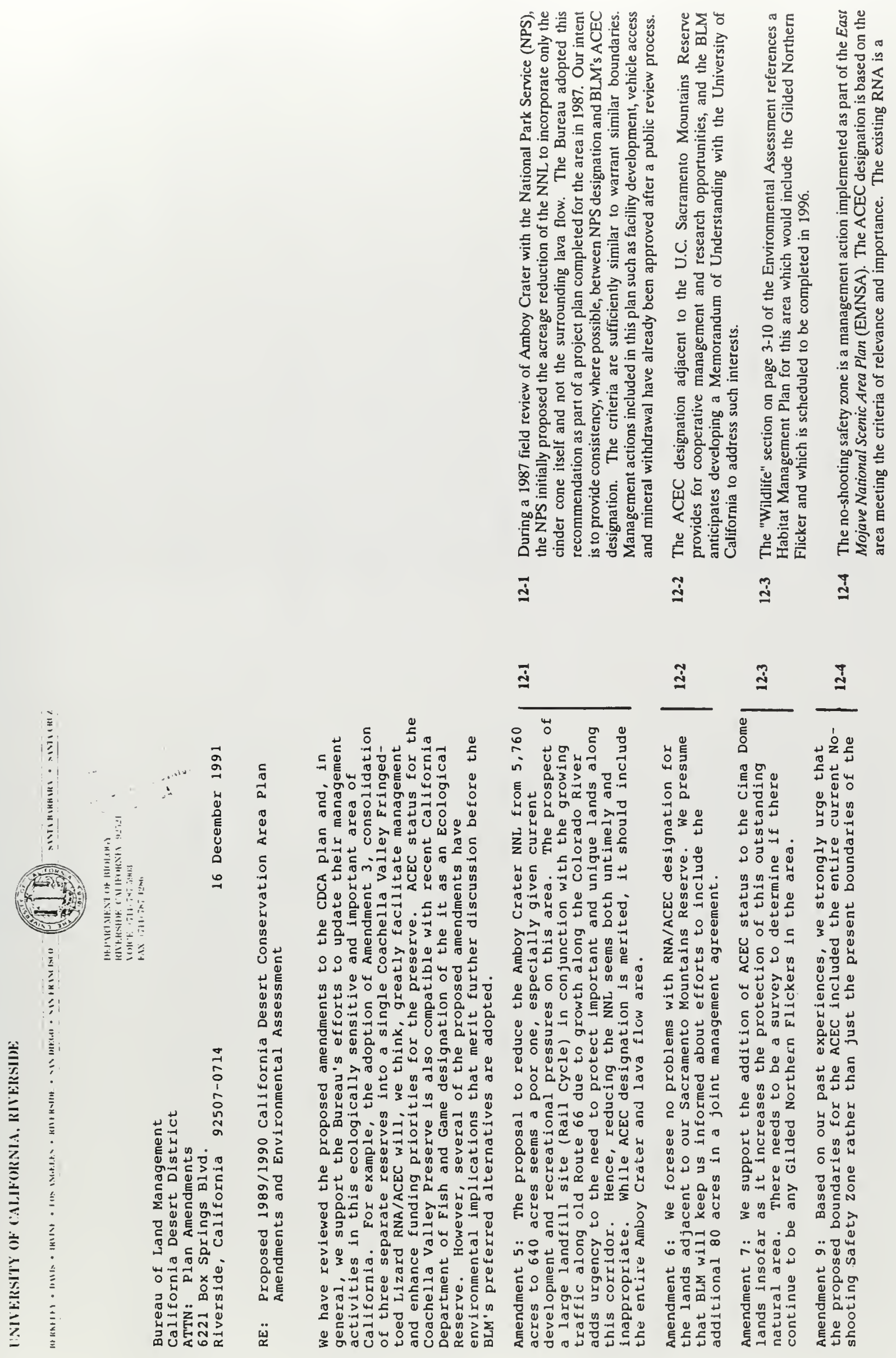


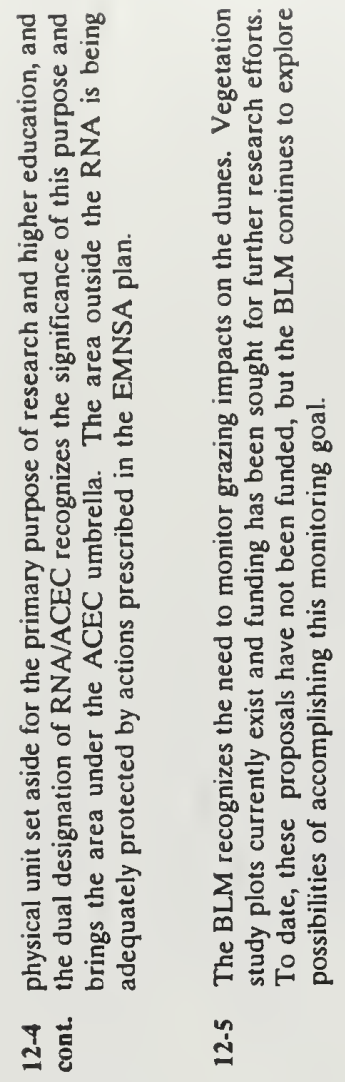

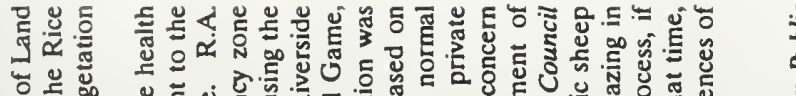

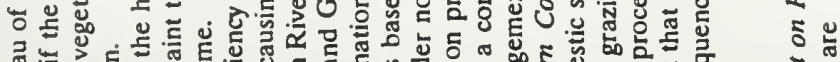

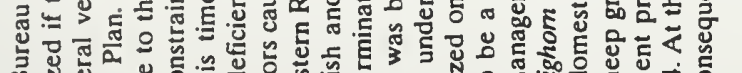

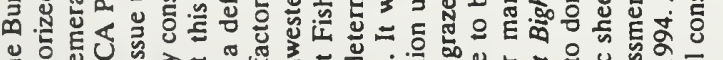

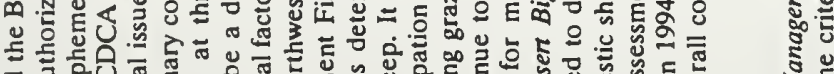

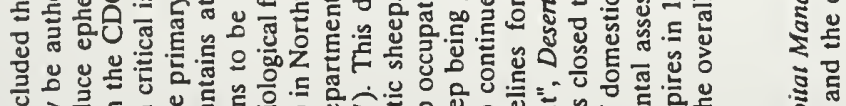

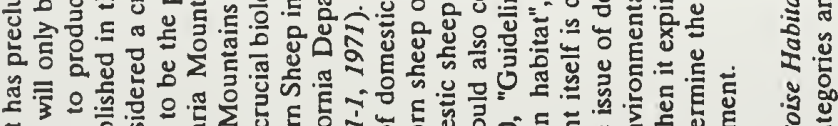

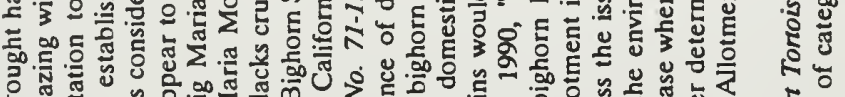

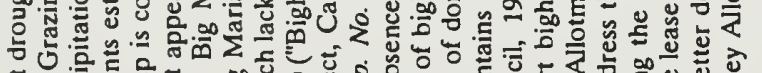

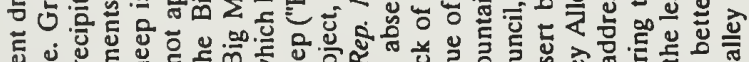

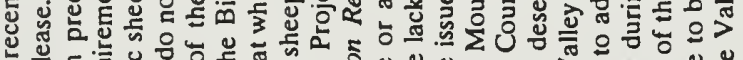

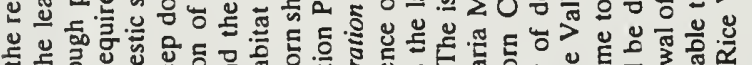

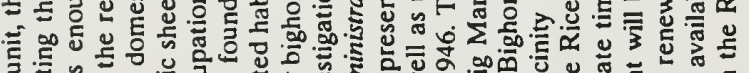
oo

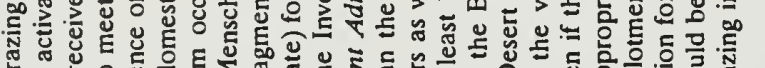

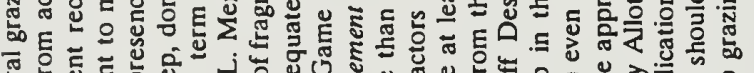

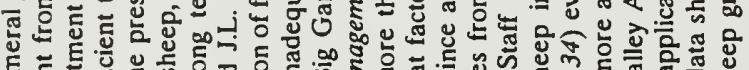

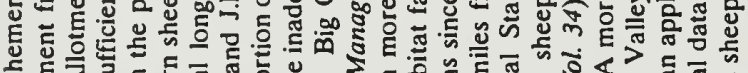

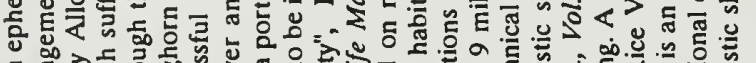

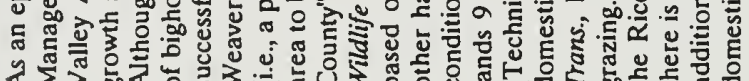

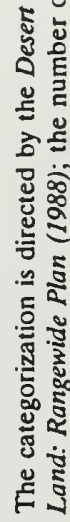
$\stackrel{ }{ }$

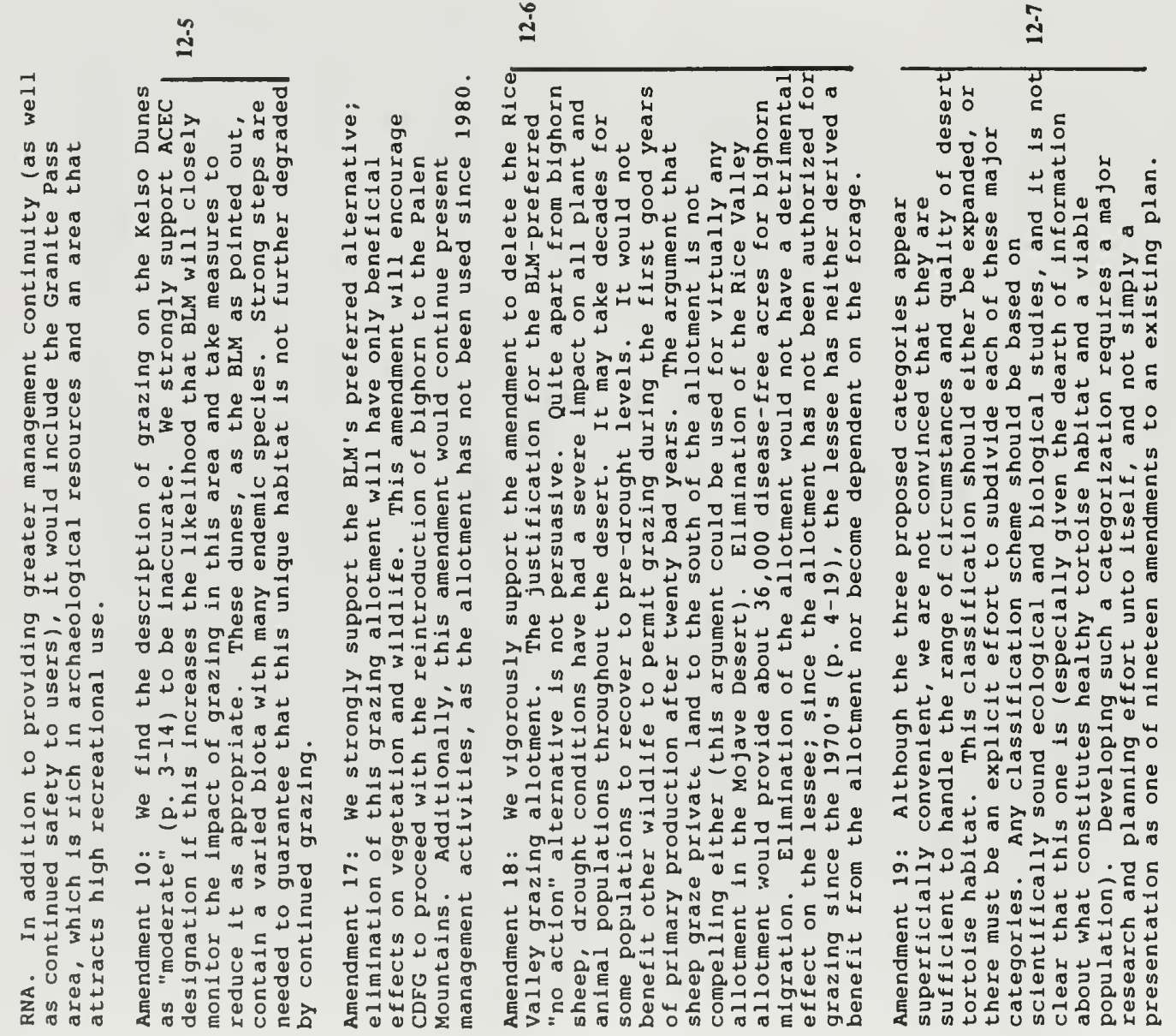



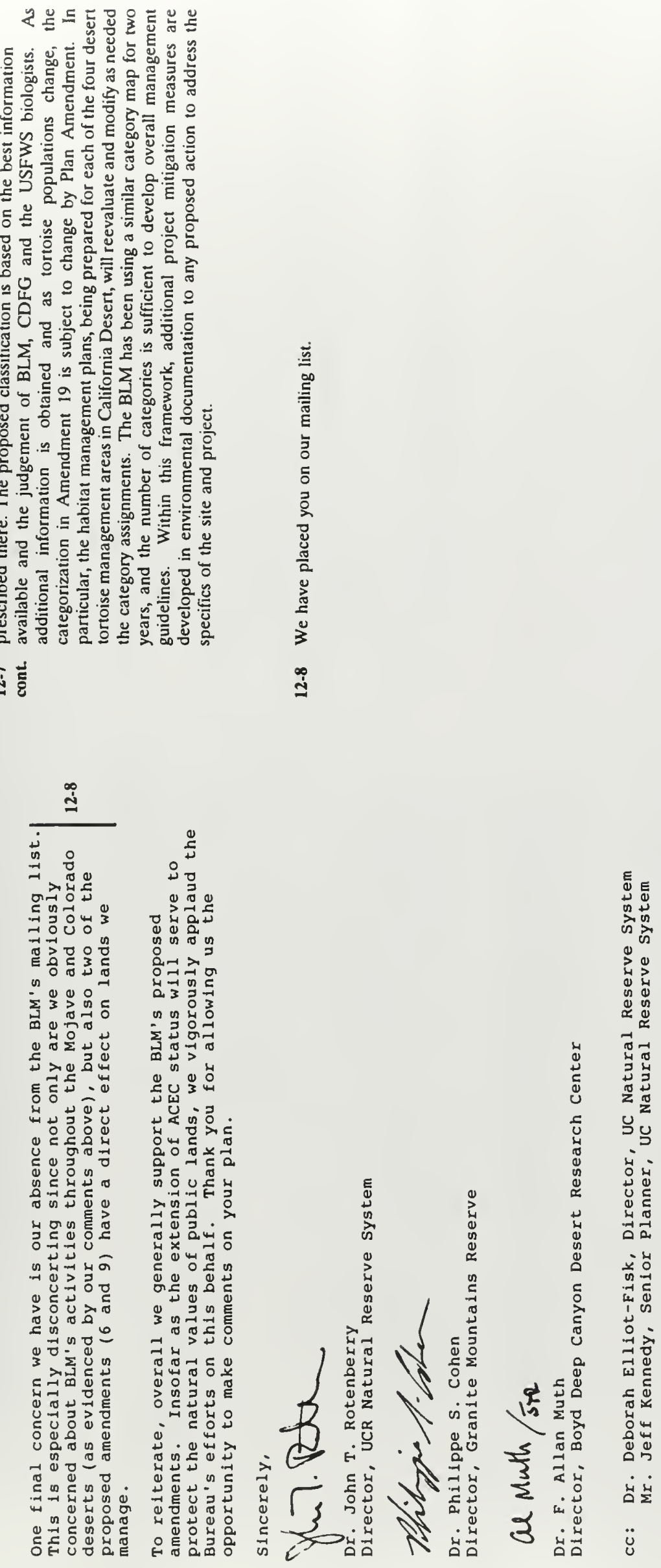
letter 13
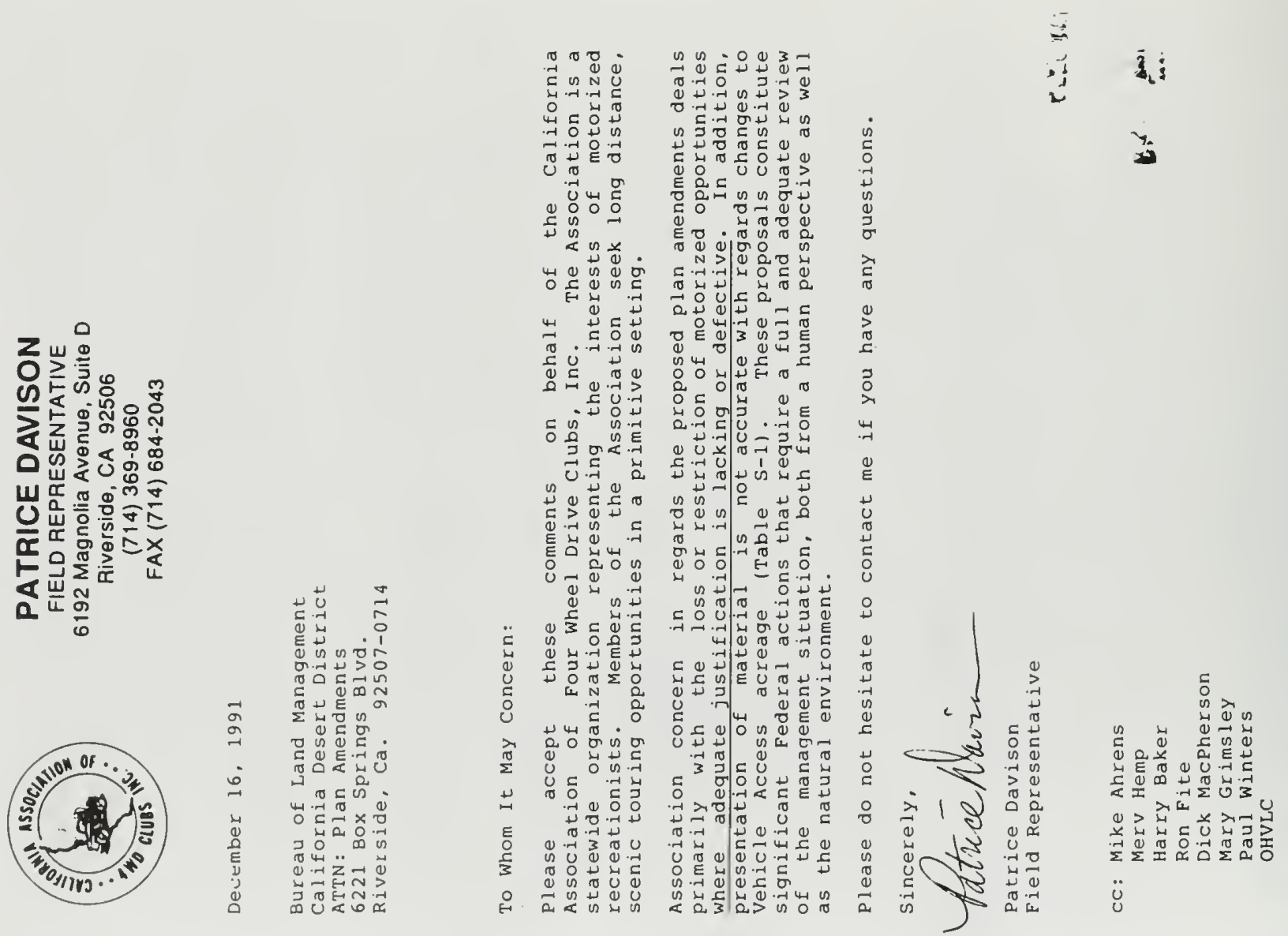

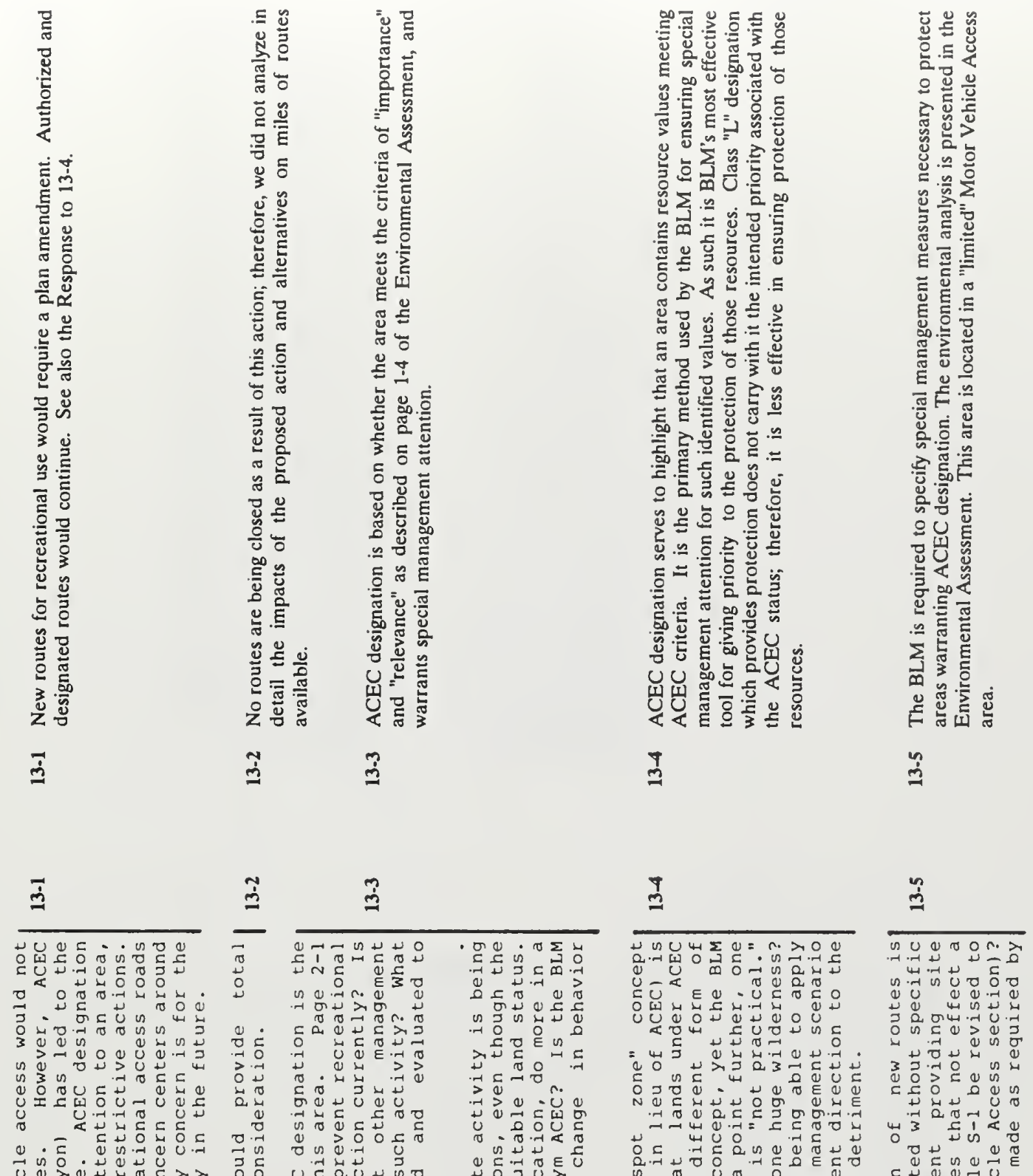

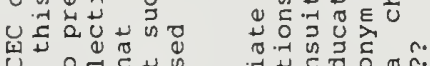

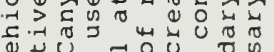

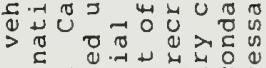

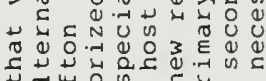

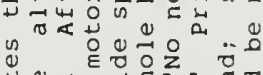

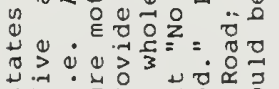

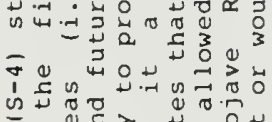

zo

एके

绍

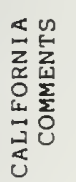

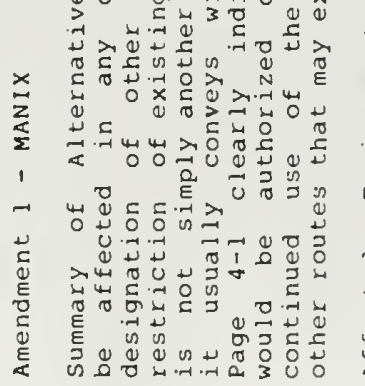

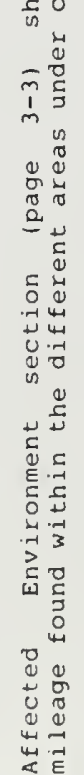

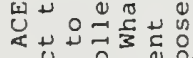

入讠义

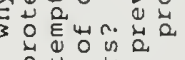

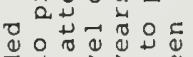

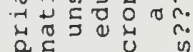

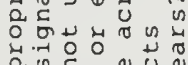

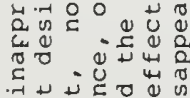

$\rightarrow+0$

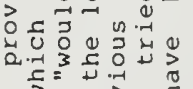

7

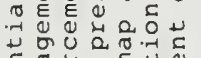
${ }^{\frac{5}{3}}=\operatorname{sid} \varepsilon^{\pi}$

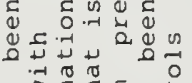

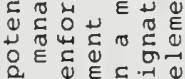

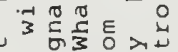

व दू दू क

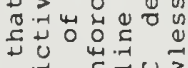

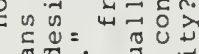

里出过

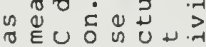

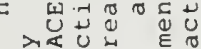

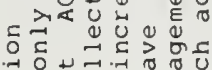

过

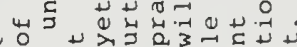

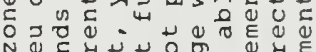

-

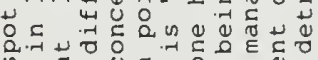

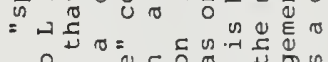
\%

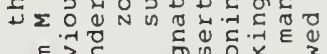

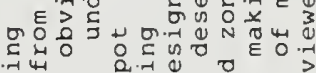

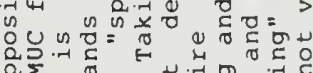

ह

बै

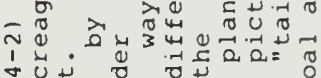

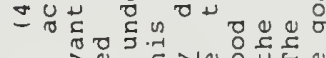

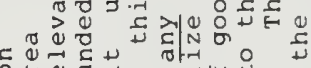

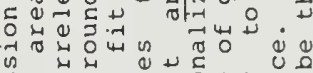

年.

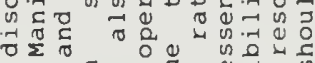

Uु

द $3>$ उ

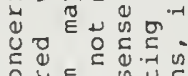

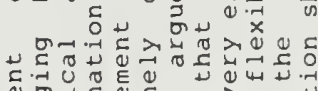

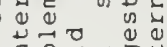

कै б.न ट है ट

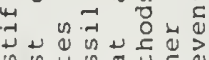

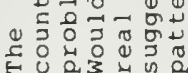

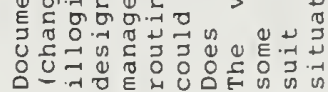

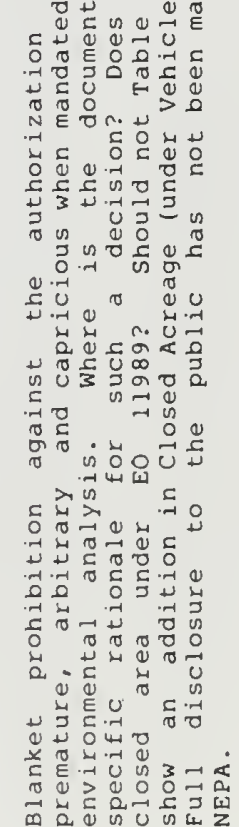



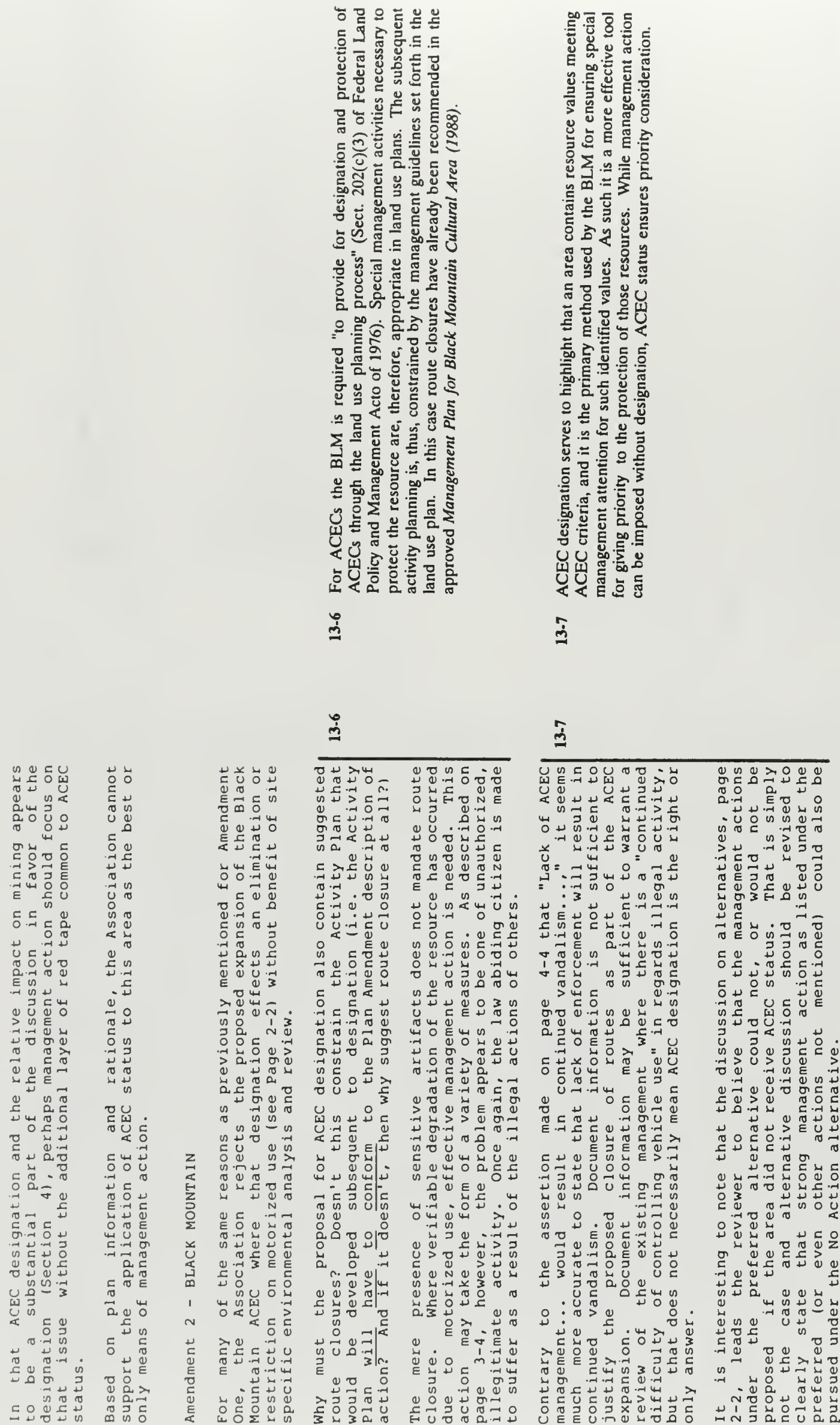

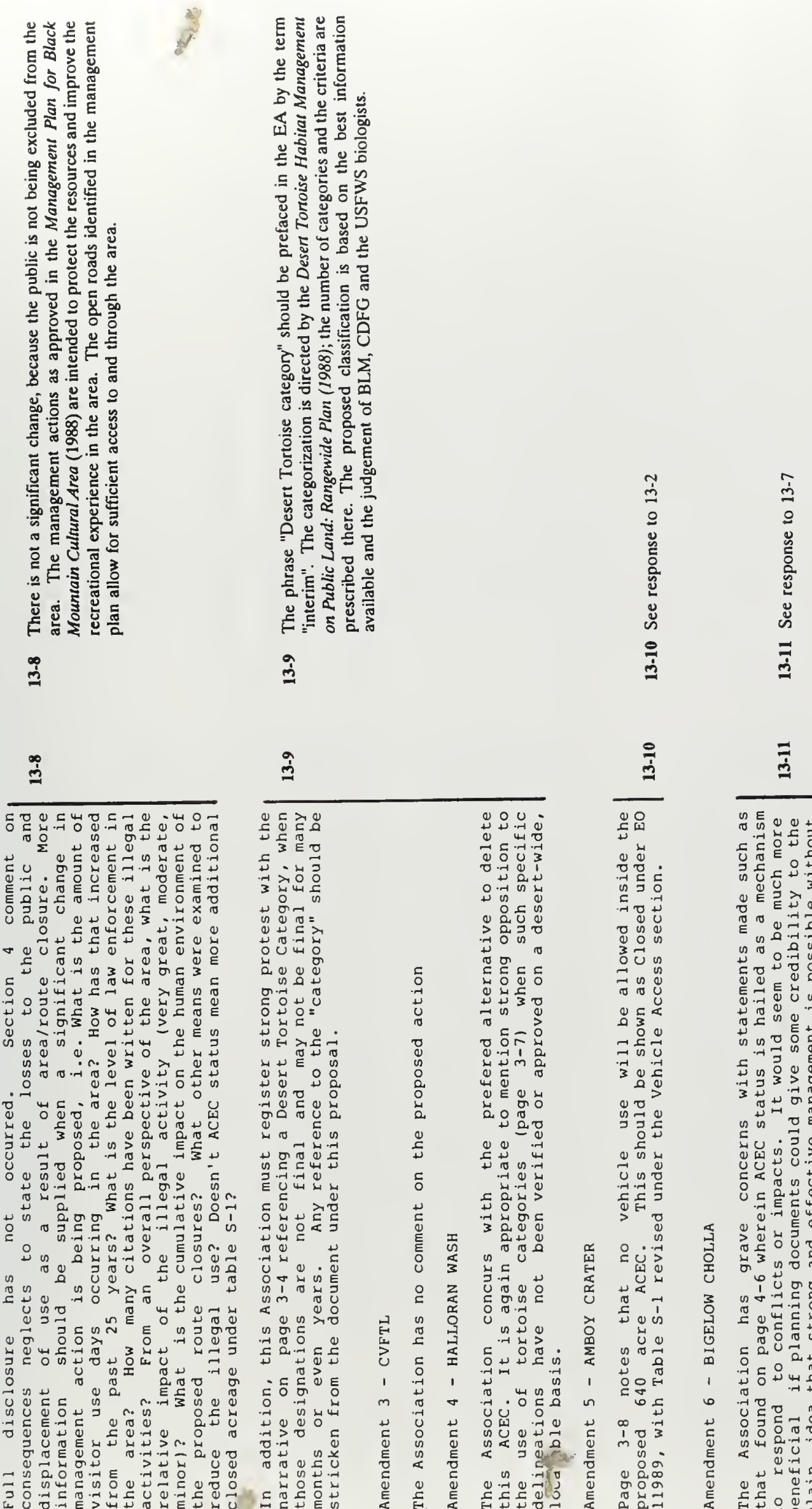

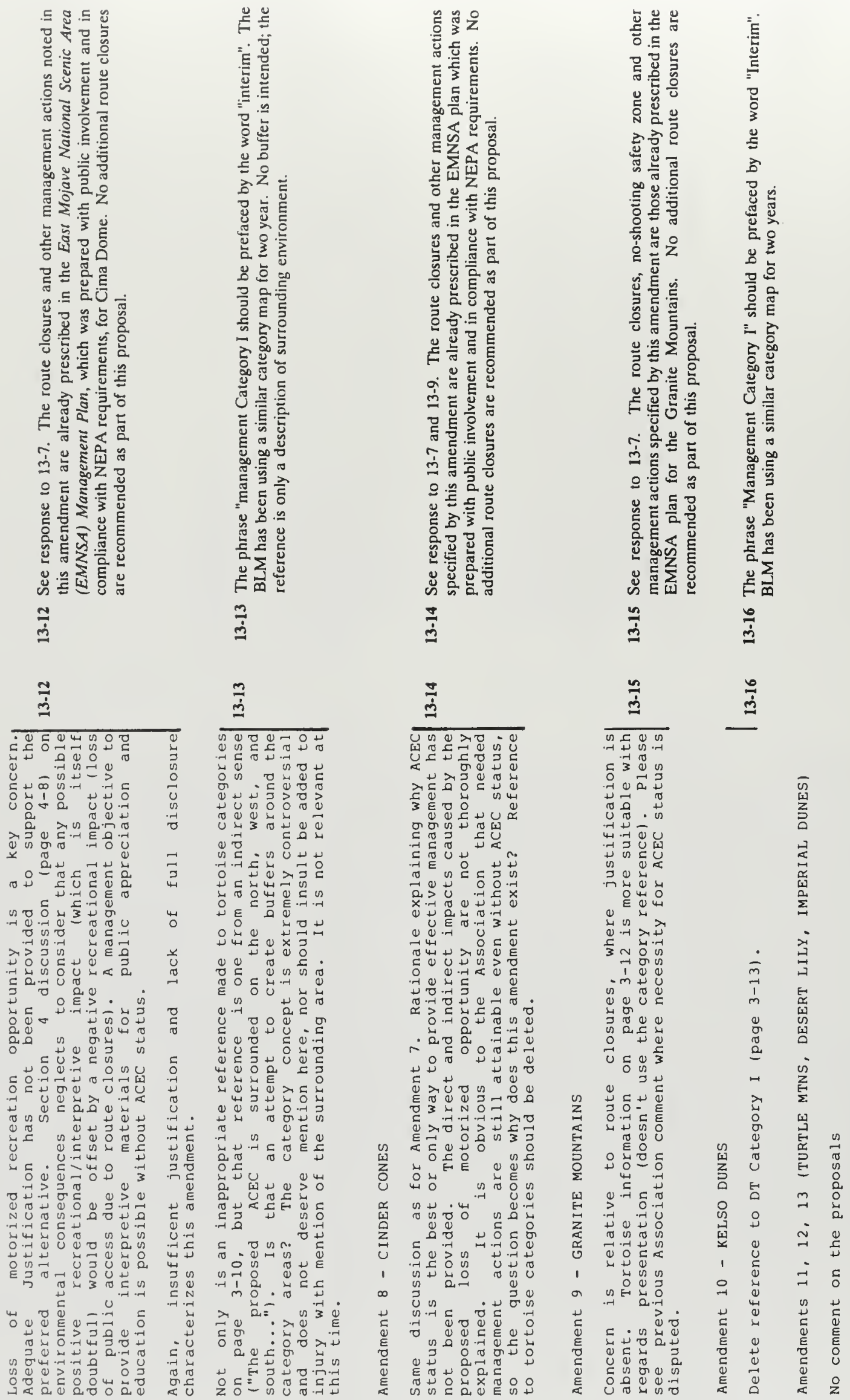


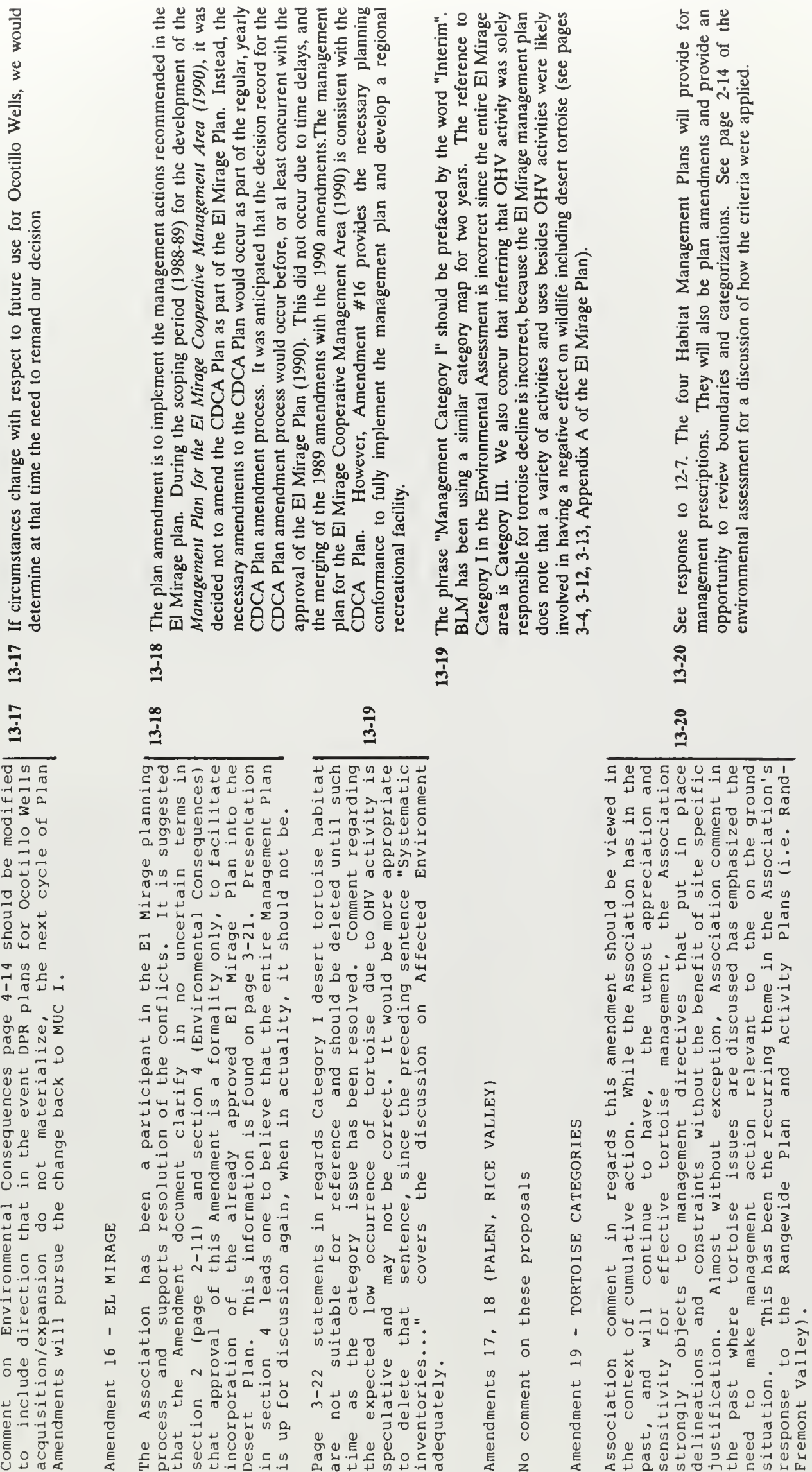




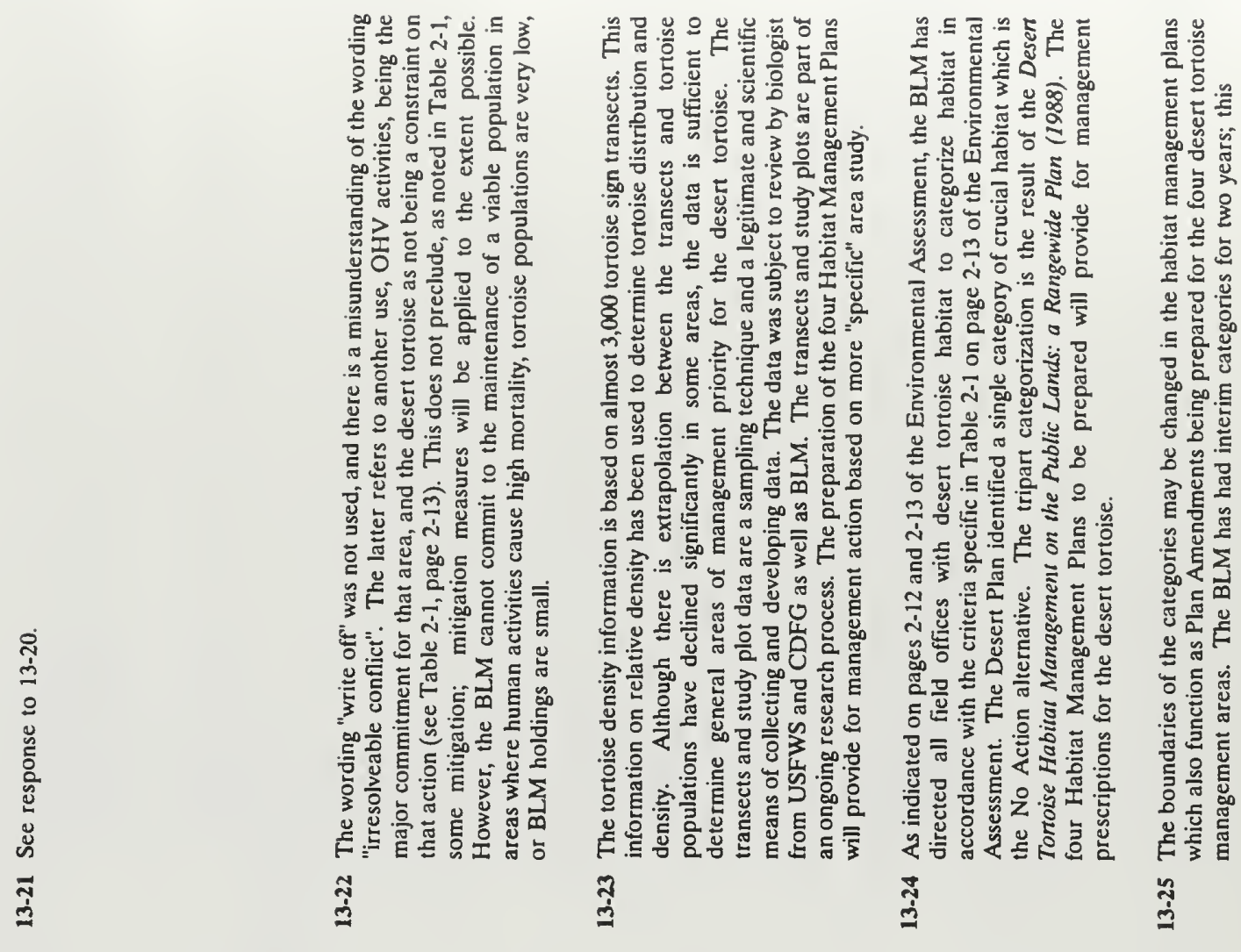

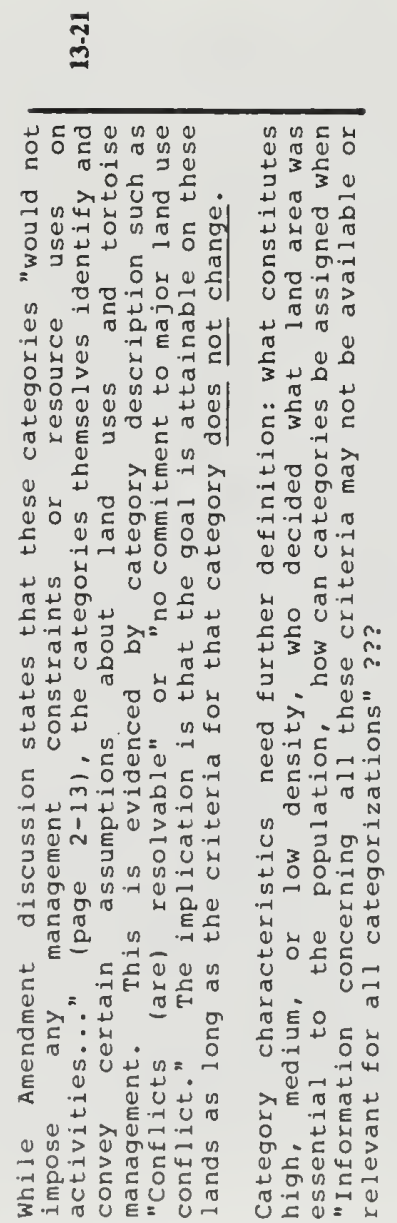

สุ

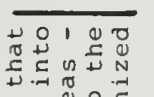

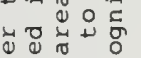

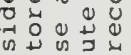

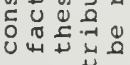

ㅇำ

ทำ

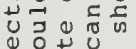

जิ ติ

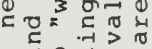

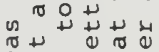

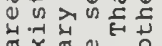

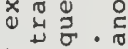

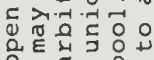

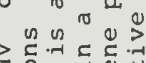

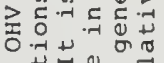

$5 \frac{\pi}{3} . \overrightarrow{1} \sigma$

过

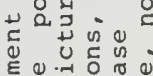

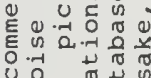

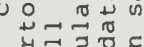

- $\begin{gathered}4 \\ +\end{gathered}$

$\sim 20$ 的

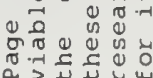

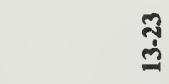

$\stackrel{9}{7}$

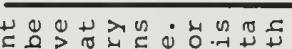

प.

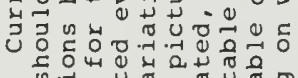

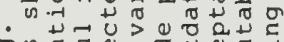

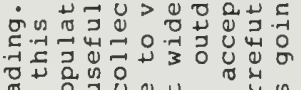

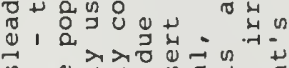

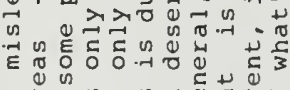

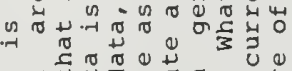

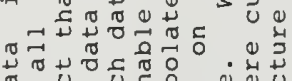

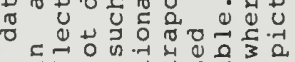

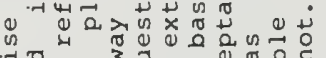

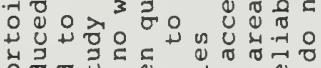

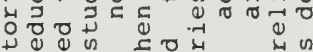

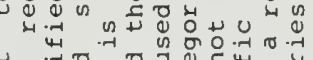

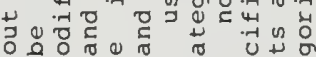

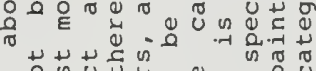

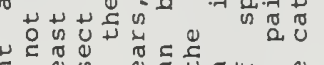

结

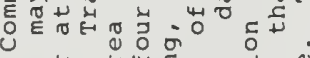

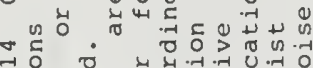

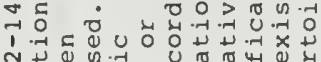

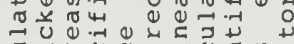

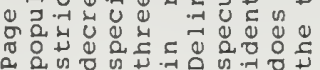

ฐ

ฆุ

Тี

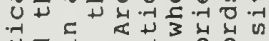

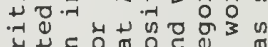
. 5

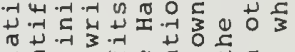

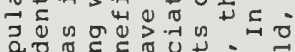

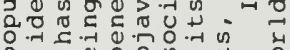

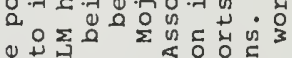

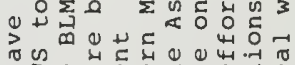

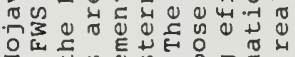

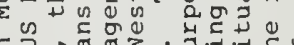

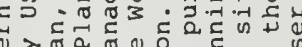

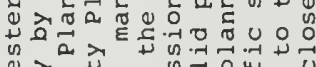
वे 3 म्ये

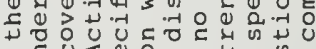
n与 出.

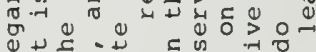

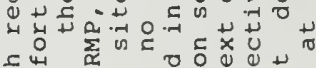

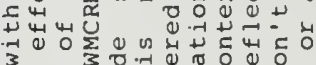

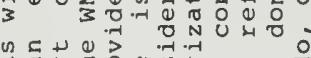
की

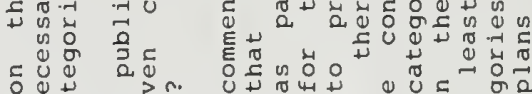
ᄀ

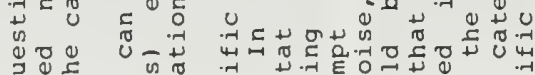

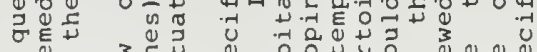

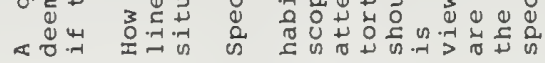



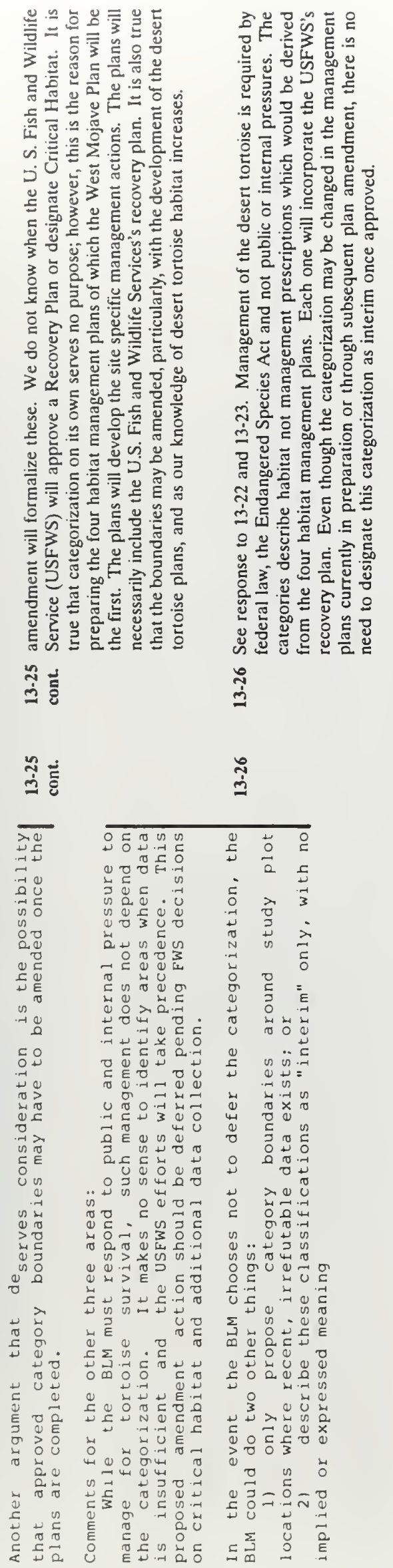


\section{letter 14}

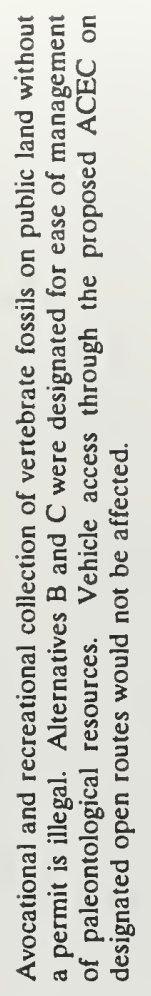

五

王

Oี

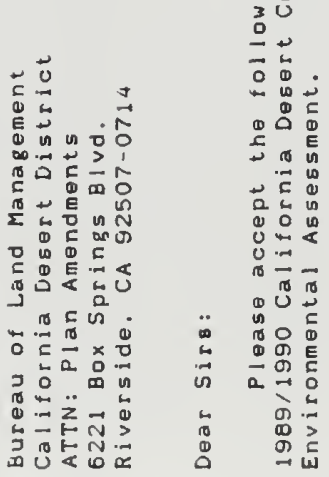

要

ํㅗㅇ

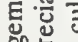

这응

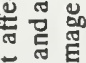

흠 品 댐

을 홀

迎总总

흥 뭉

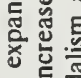

들

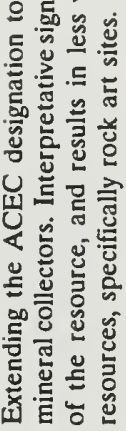

I

$\stackrel{+}{ \pm}$

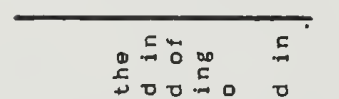

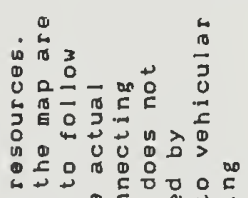

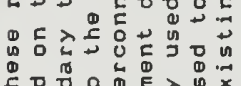

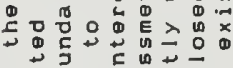

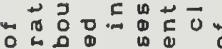

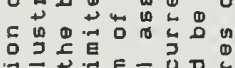

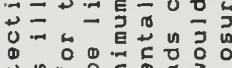

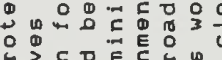

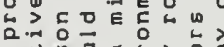

由

势

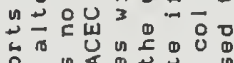

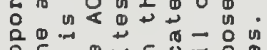

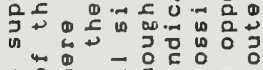

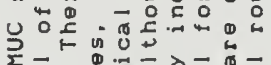

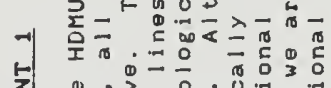

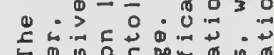

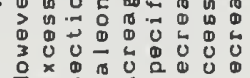

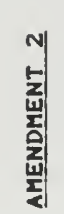

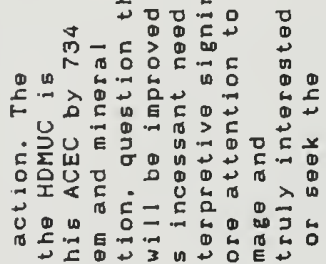

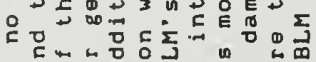

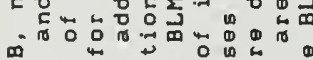

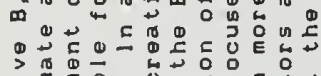

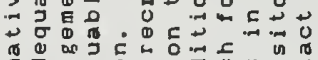

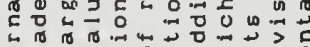

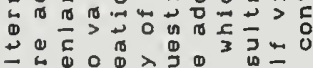

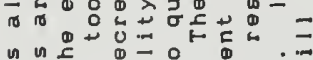

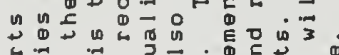

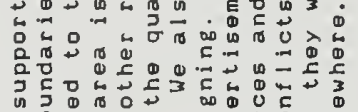

U

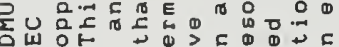

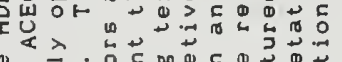

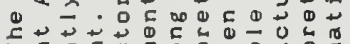

管

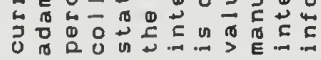

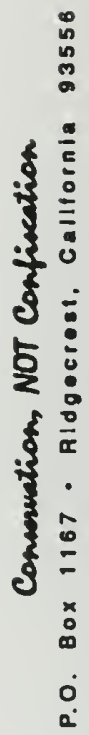




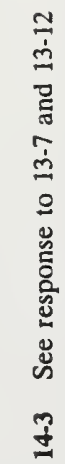

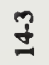

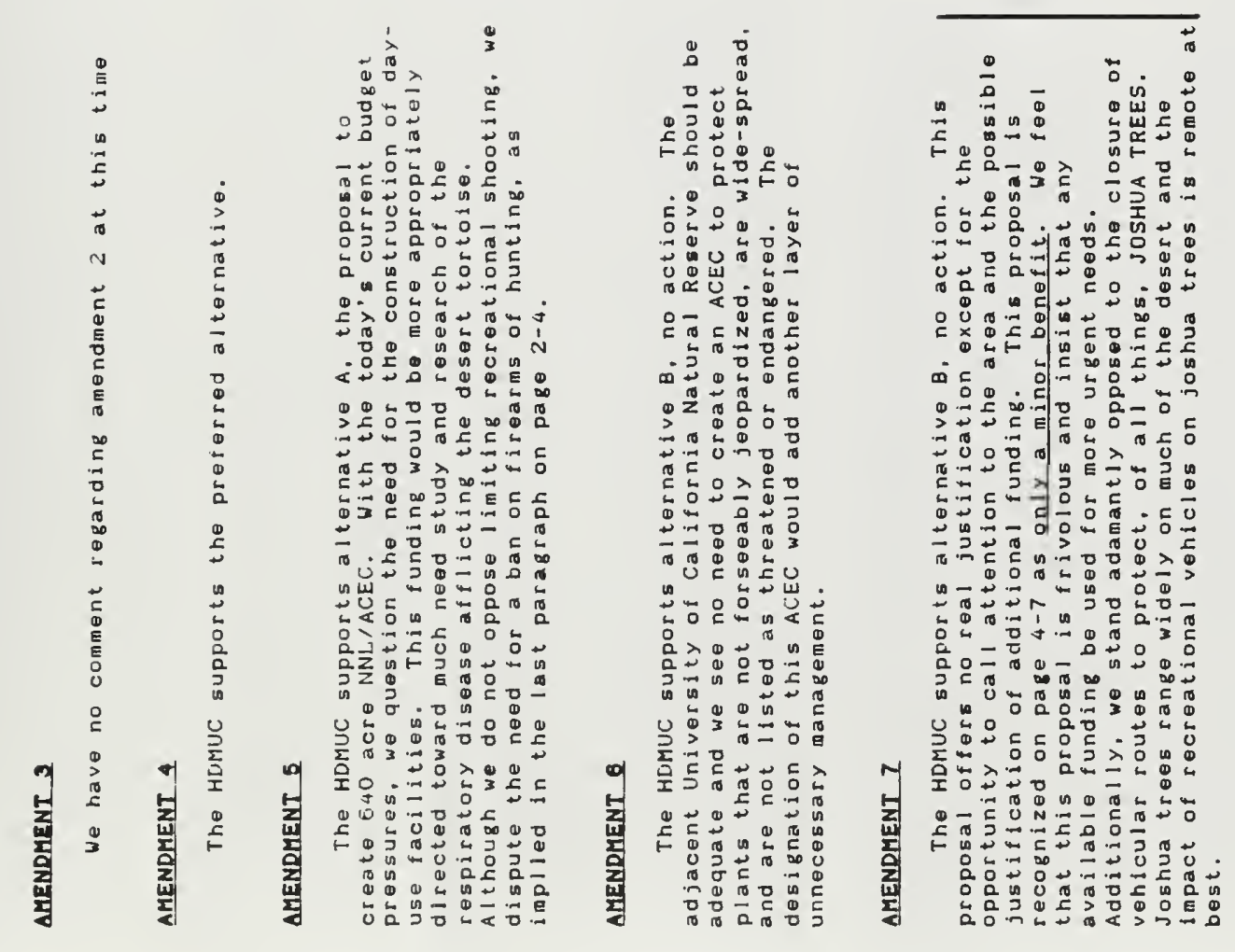



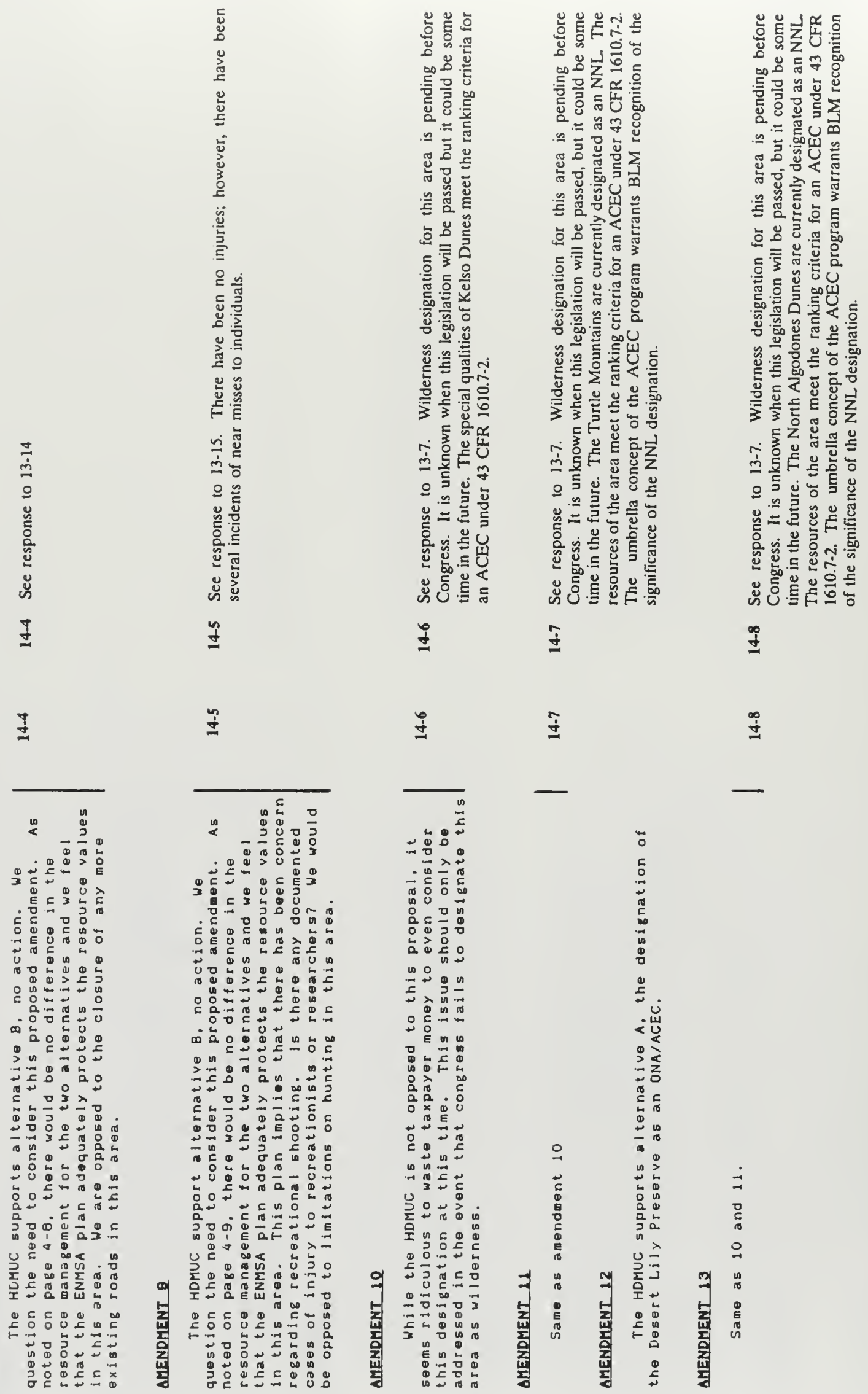


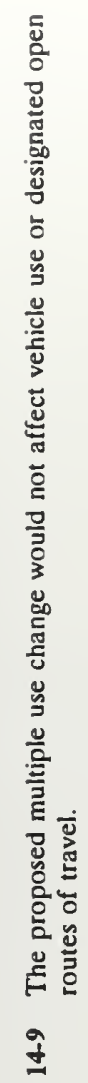

q

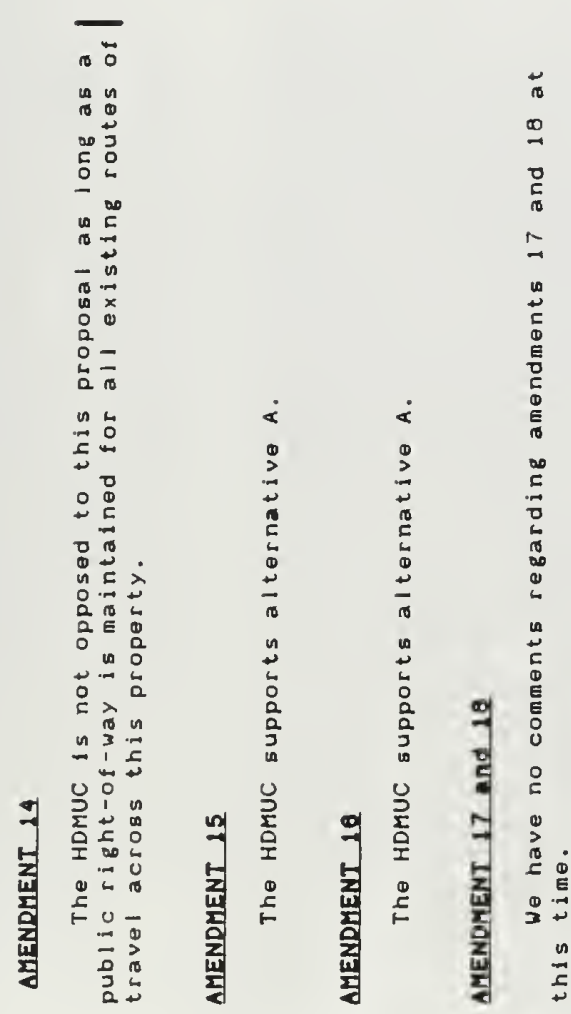

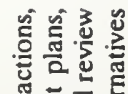
- 돌 ธूँ 㺃 है छ क्ิ + 稌 哭空 으옹 들.

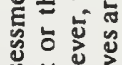
定论

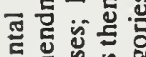
ह

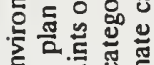
号 을

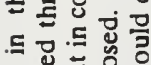

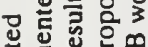

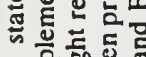

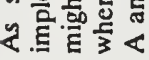

옹

$\frac{7}{9}$

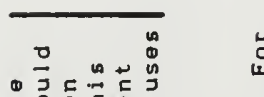

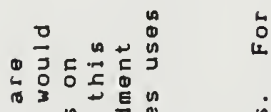

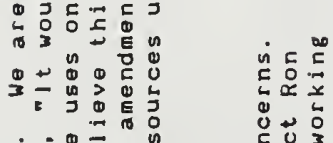

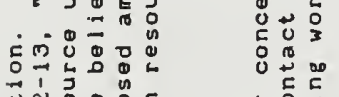

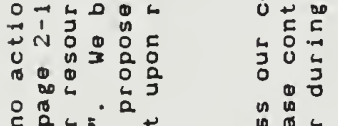
由.

计

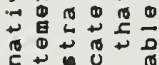

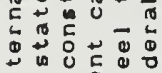

नि

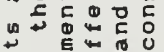

पि

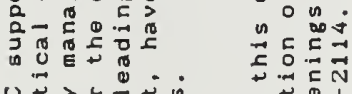

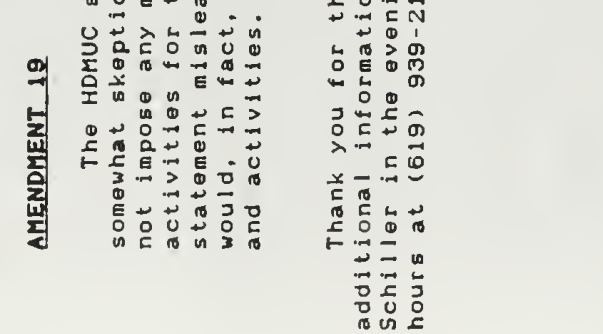




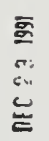

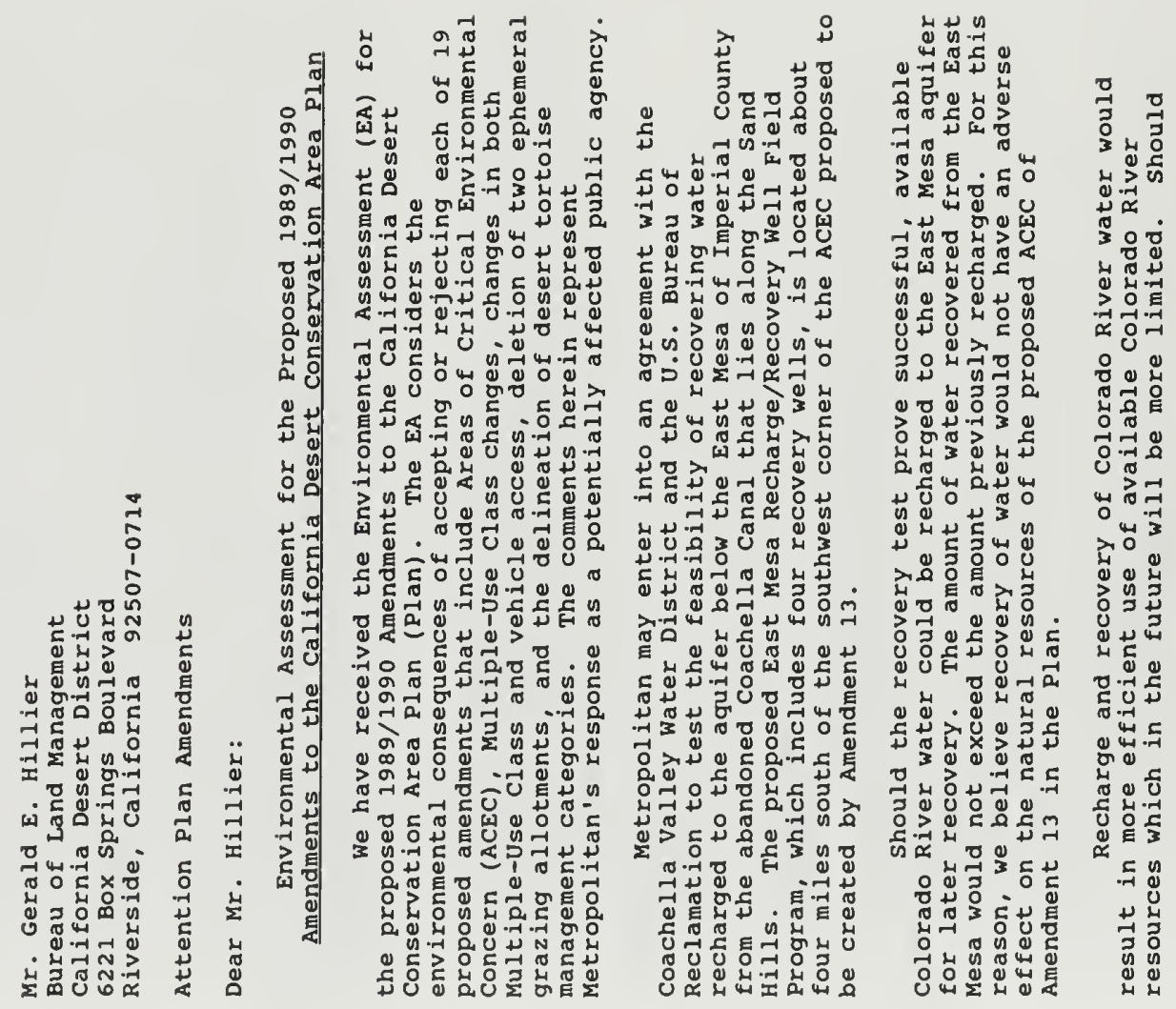




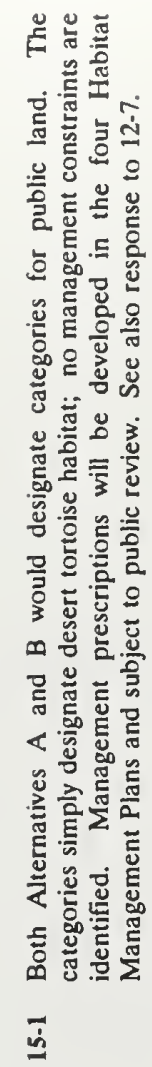

$\overline{\dot{g}}$
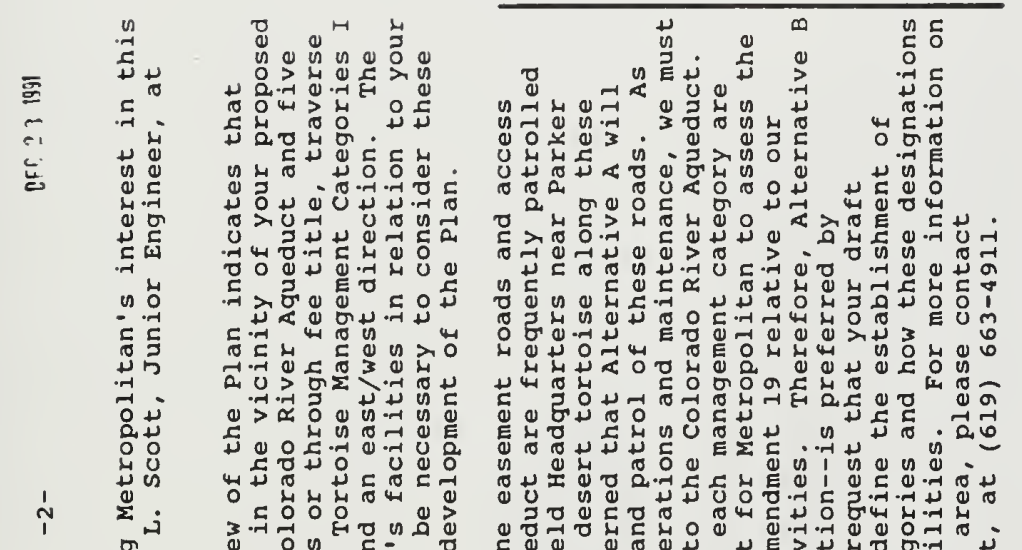

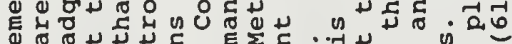

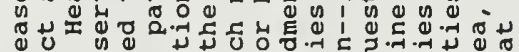

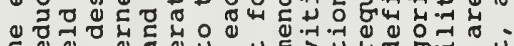

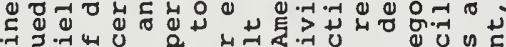

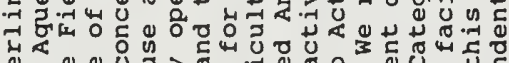

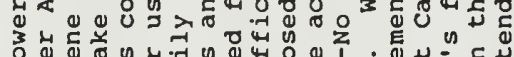
3.

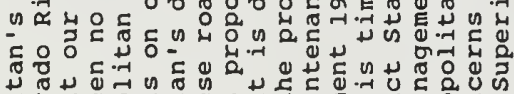

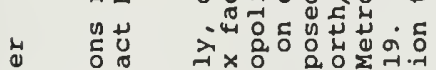

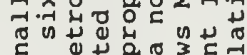

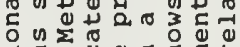

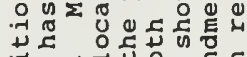
वृ 我 응영

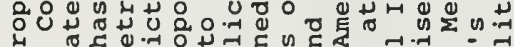

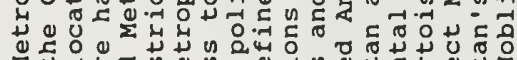

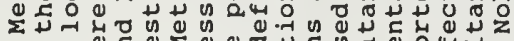

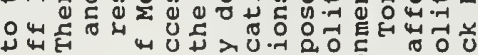

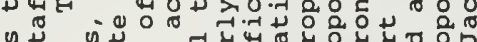

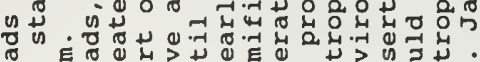

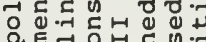

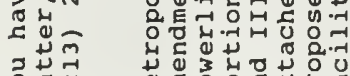

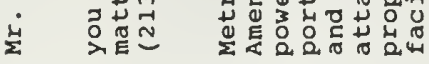

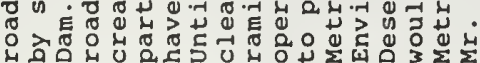

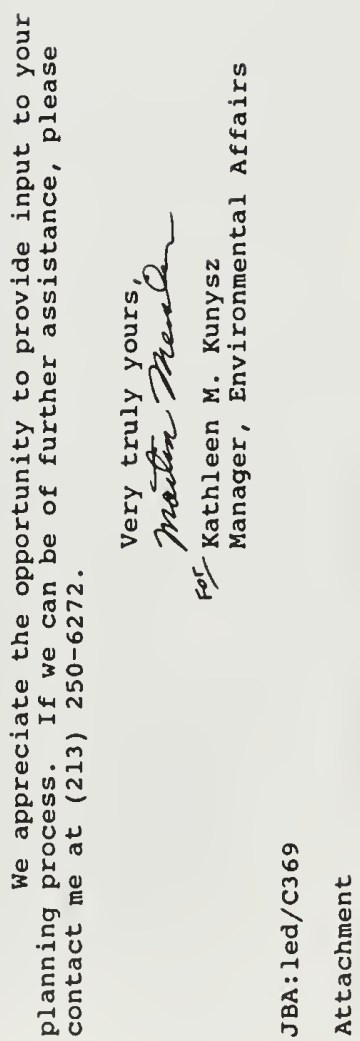




\section{letter 16}

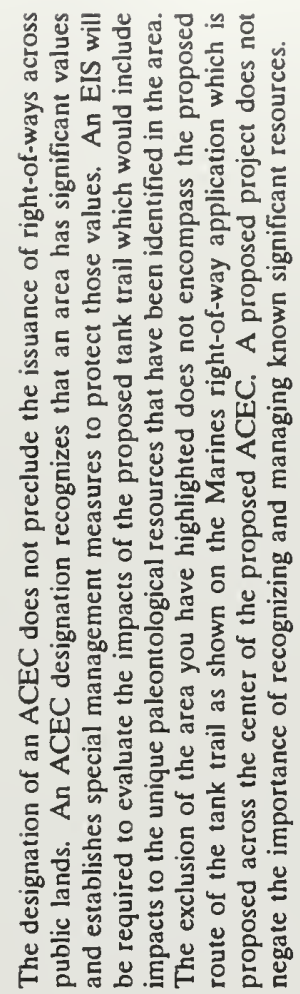

bे

$\overline{\underline{B}}$
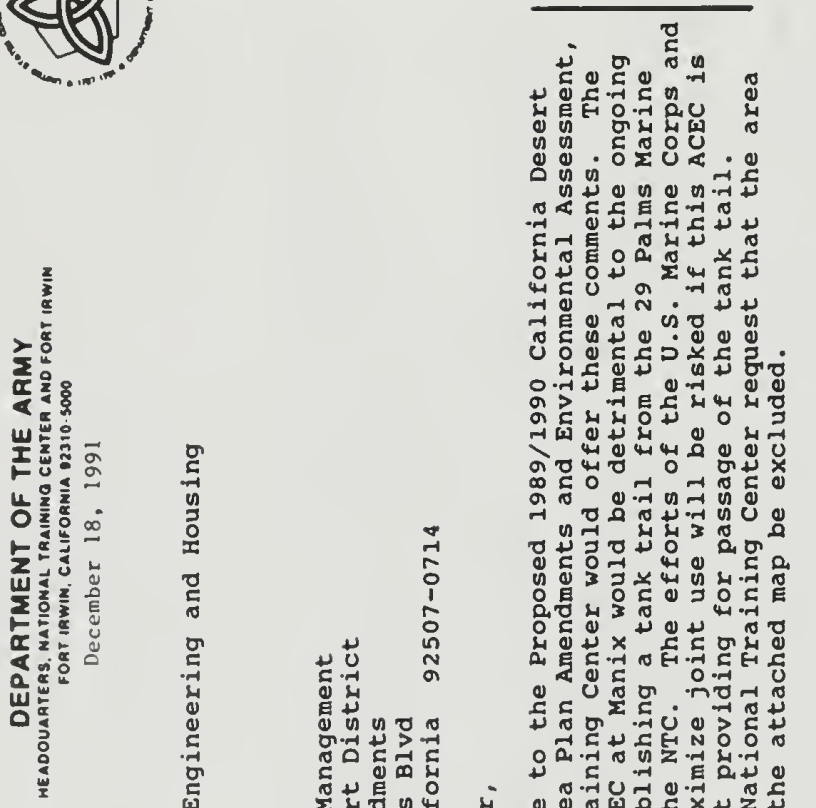

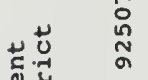

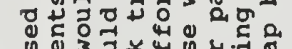

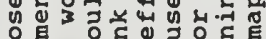

음

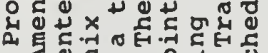

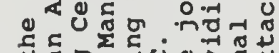

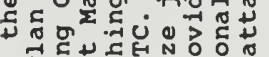

울.न

0.

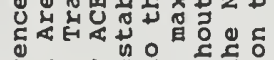

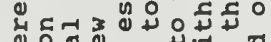

में

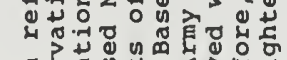

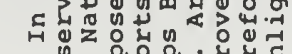

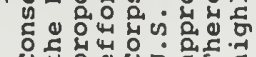

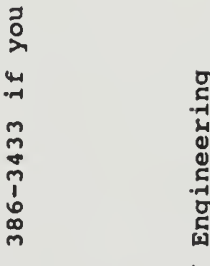

ने वे कि

牙

हू.

N密出 
Appendices

2 


\section{APPENDIX A}

\section{SPECIAL AREA DESIGNATIONS RECOMMENDED FOR DELETION*}

Former Special Areas

Designation**

Former Present
Rationale for Deletion of Special Area Designation
Amargosa Canyon

Amargosa Canyon/Dumont Dunes

Argus Mountain

Black Mountain

(El Paso Mountain)

Bow Willow Palms

Carruthers Canyon

Cerro Coso College

Crucifixion Thorn

Darwin Falls

Dead Indian Creek

Desert Tortoise

Dove Springs, Butterbread, NA Water Canyon

Eureka Dunes

NA

NA

NA

NA

NA
ACEC

ACEC

Amargosa Canyon ACEC (No. 13)

(CDCA Plan, 1980)

Amargosa Canyon ACEC (No. 13); Dumont Dunes OHV Area (CDCA Plan, 1980)

PA -----

PA

RNA

$-\cdots-\cdot$

ONA

-----

RNA

ONA ACEC

NSA

NA RNA/ACEC
Did not meet WSA or ACEC criteria

In El Paso WSA (CDCA-164) (CDCA Plan, 1980)

In In-Ko-Pah WSA (CDCA-368) (CDCA Plan, 1980)

In New York Mountains ACEC (No. 31), (CDCA Plan, 1980)

Not qualified for ACEC status

In Yuha Basin ACEC, (No. 64) (CDCA Plan as amended, 1986)

Darwin Falls ACEC (No. 6), (CDCA Plan, 1980)

In Santa Rosa Mtns. National Scenic Area (CDCA Plan Amendment,1990)

Desert Tortoise Research Natural Area (ACEC No. 22) (CDCA Plan, 1980)

ACEC

In Jawbone/Butterbread ACEC

(No. 20), (CDCA Plan, 1980)

ACEC
Eureka Dunes ACEC (No. 3), (CDCA Plan, 1980) 


\section{SPECIAL AREA DESIGNATIONS RECOMMENDED FOR DELETION (cont.)}

Former Special Areas
Designation

Former
Present
Rationale for Deletion of Special Area Designation

\begin{tabular}{|c|c|c|c|}
\hline Fossil Canyon & NA & ACEC & $\begin{array}{l}\text { In Coyote Mountains ACEC, (No. 62), } \\
\text { (CDCA Plan, 1980) }\end{array}$ \\
\hline Great Falls Basin & RNA & ACEC & $\begin{array}{l}\text { Great Falls Basin/Argus Range ACEC, } \\
\text { (No. 12), (CDCA Plan, 1980) }\end{array}$ \\
\hline Indian Springs & ONA & $-\cdots---$ & $\begin{array}{l}\text { In New York Mtn. ACEC, (No. 31), } \\
\text { (CDCA Plan, 1980) }\end{array}$ \\
\hline Jacumba & ONA & ------ & $\begin{array}{l}\text { In recommended In-Ko-Pah WSA } \\
\text { (CDCA-386), (CDCA Plan, 1980) }\end{array}$ \\
\hline Milpitas Wash & RNA & ----- & Within a habitat management area. \\
\hline Mopah Springs & NA/NRL & ACEC & $\begin{array}{l}\text { Incorporated into Turtle Mtn. ACEC } \\
\text { (CDCA Plan, 1989-90) }\end{array}$ \\
\hline Rainbow Basin & ONA/NRL & ACEC & $\begin{array}{l}\text { Rainbow Basin/Owl Canyon ACEC, } \\
\text { (No. 39), (CDCA Plan, 1980) }\end{array}$ \\
\hline Signal Mountain & RNA & --.--- & $\begin{array}{l}\text { In Yuha Basin ACEC (No. 64), } \\
\text { (CDCA Plan, 1980) }\end{array}$ \\
\hline Trona Pinnacles & NA/NRL & ------ & $\begin{array}{l}\text { Trona Pinnacles ACEC, (No. 16), } \\
\text { (CDCA Plan 1980) }\end{array}$ \\
\hline Western Mojave Saltbush & RNA & ACEC/ & $\begin{array}{l}\text { Barstow Wooly Sunflower ACEC, } \\
\text { (No. 36), (CDCA Plan 1980); } \\
\text { Western Mojave Saltbush UPA }\end{array}$ \\
\hline
\end{tabular}

* Plan Clarification

** Special Area Designations: ACEC $=$ Area of Critical Environmental Concern; NA $=$ Natural Area; NRL $=$ National Recreation Lands; NSA = National Scenic Area; ONA = Outstanding Natural Area; PA = Primitive Area; RNA = Research Natural Area; UPA = Unusual Plant Assemblage; WSA $=$ Wilderness Study Area 


\begin{tabular}{|c|c|c|c|}
\hline 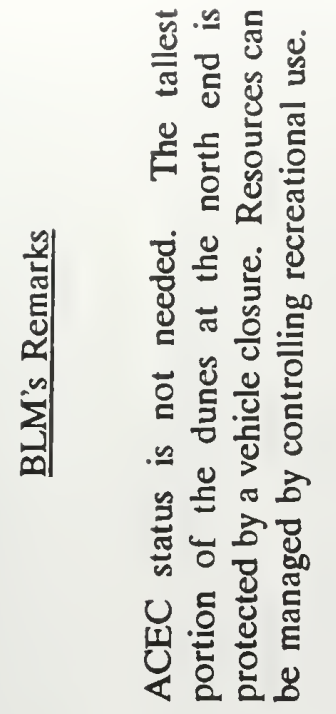 & 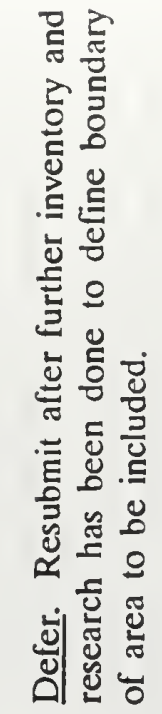 & 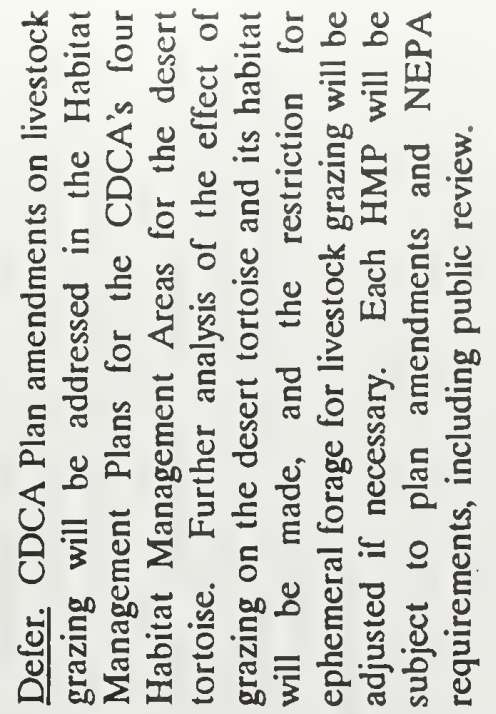 & 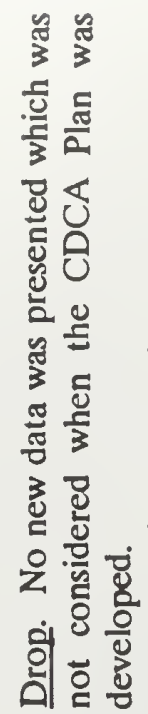 \\
\hline
\end{tabular}

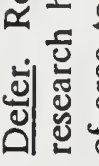

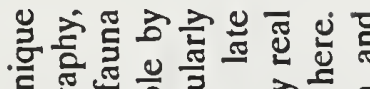

嵌

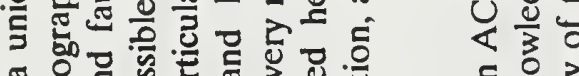

들

荡造

药

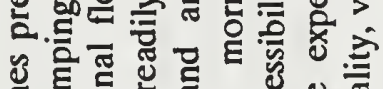

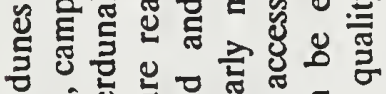

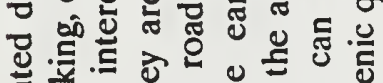

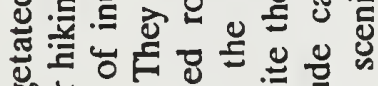

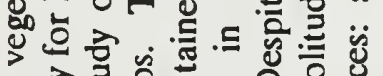

.

定믁을

帘范

乙语

온.

至号

$x$

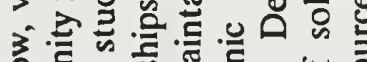

空

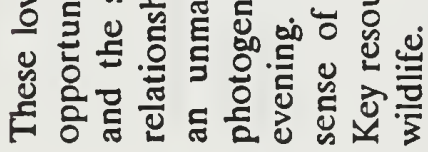

응 응

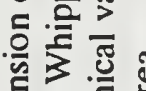

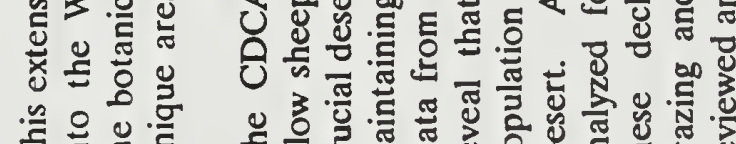

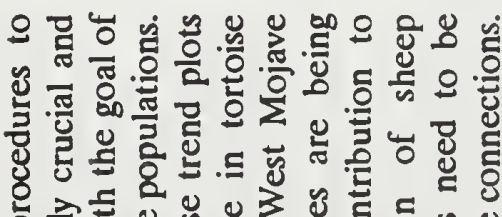

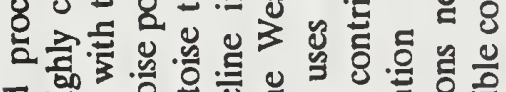

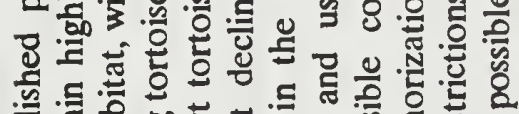

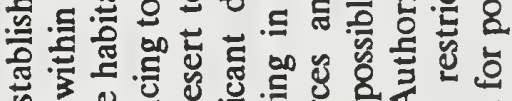

今

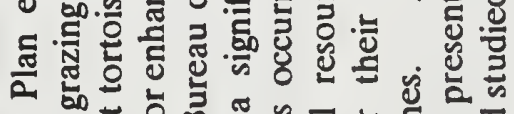

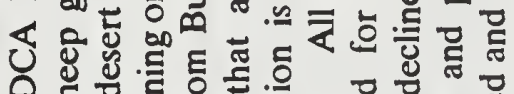

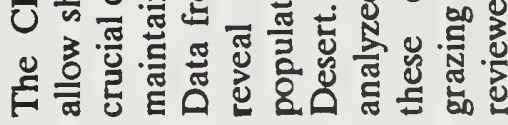

రั口:

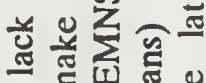

政

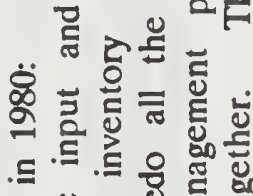

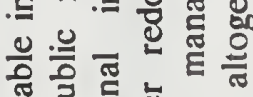

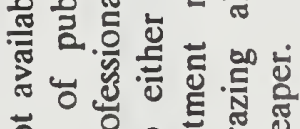

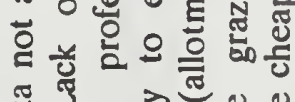

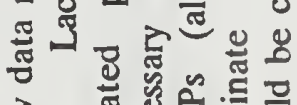

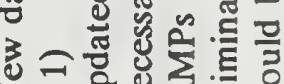

魚峦

安哭

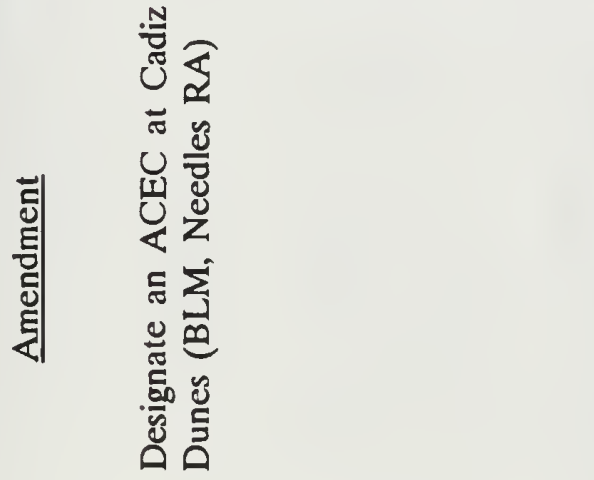

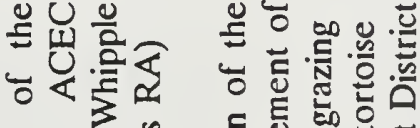

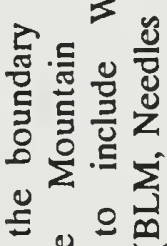

들

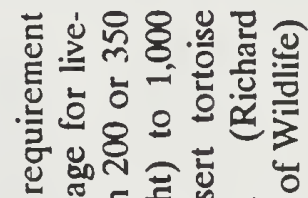

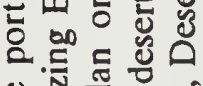

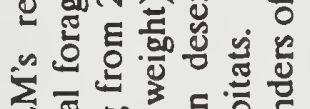

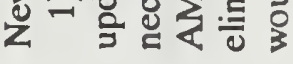

0 这

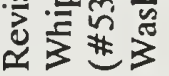

o $0<$.

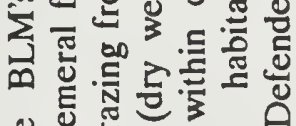

욜.

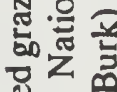

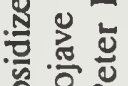

s:

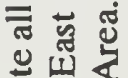

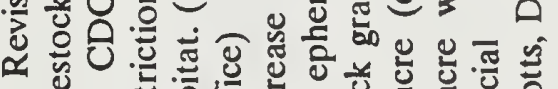

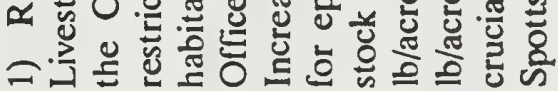

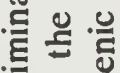

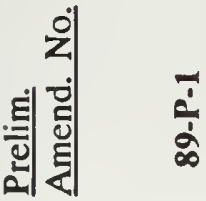

玄

$\frac{8}{\frac{0}{1}}$

$\frac{\text { กี }}{\frac{1}{1}}$ 
武

“

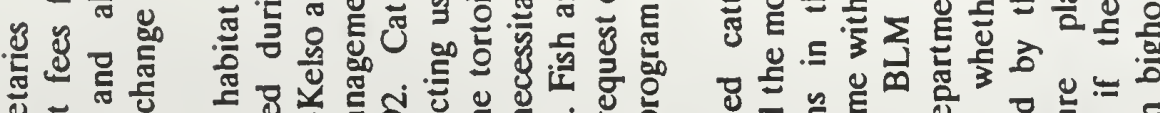

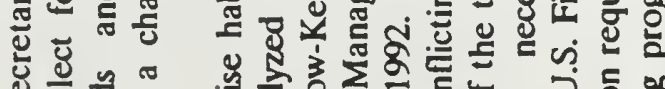

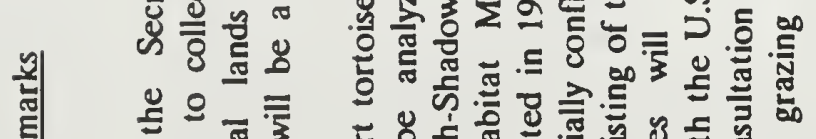

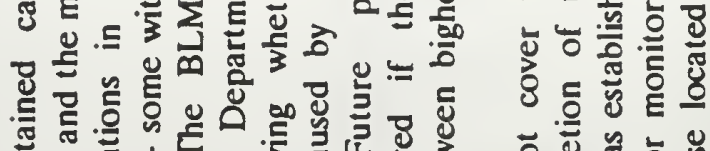

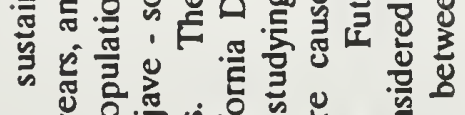

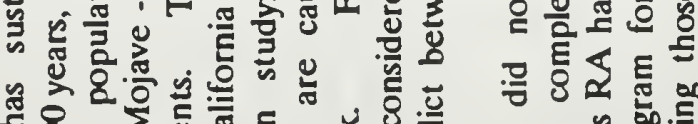

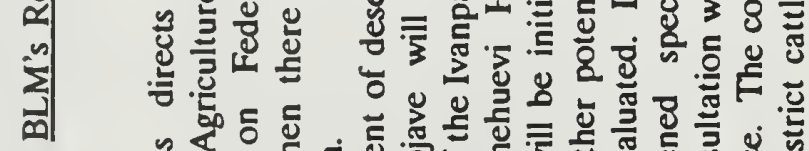

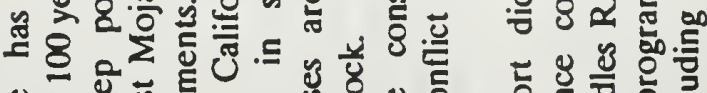

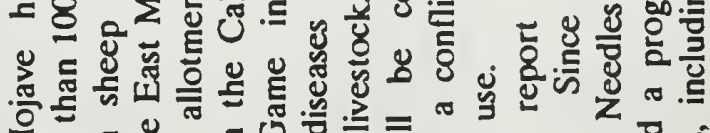

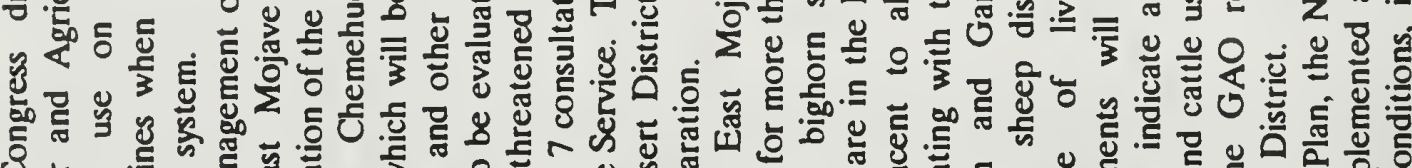

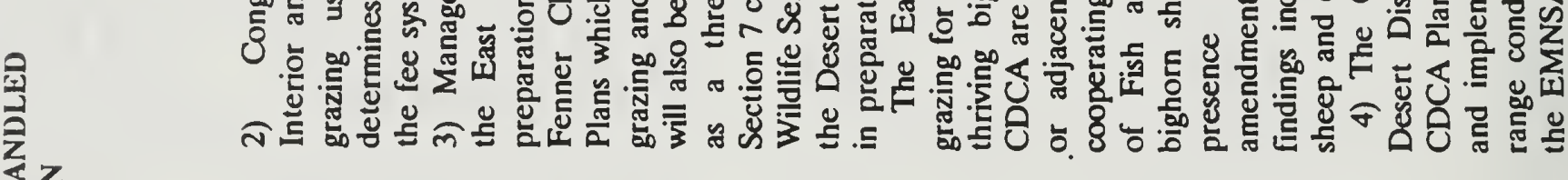
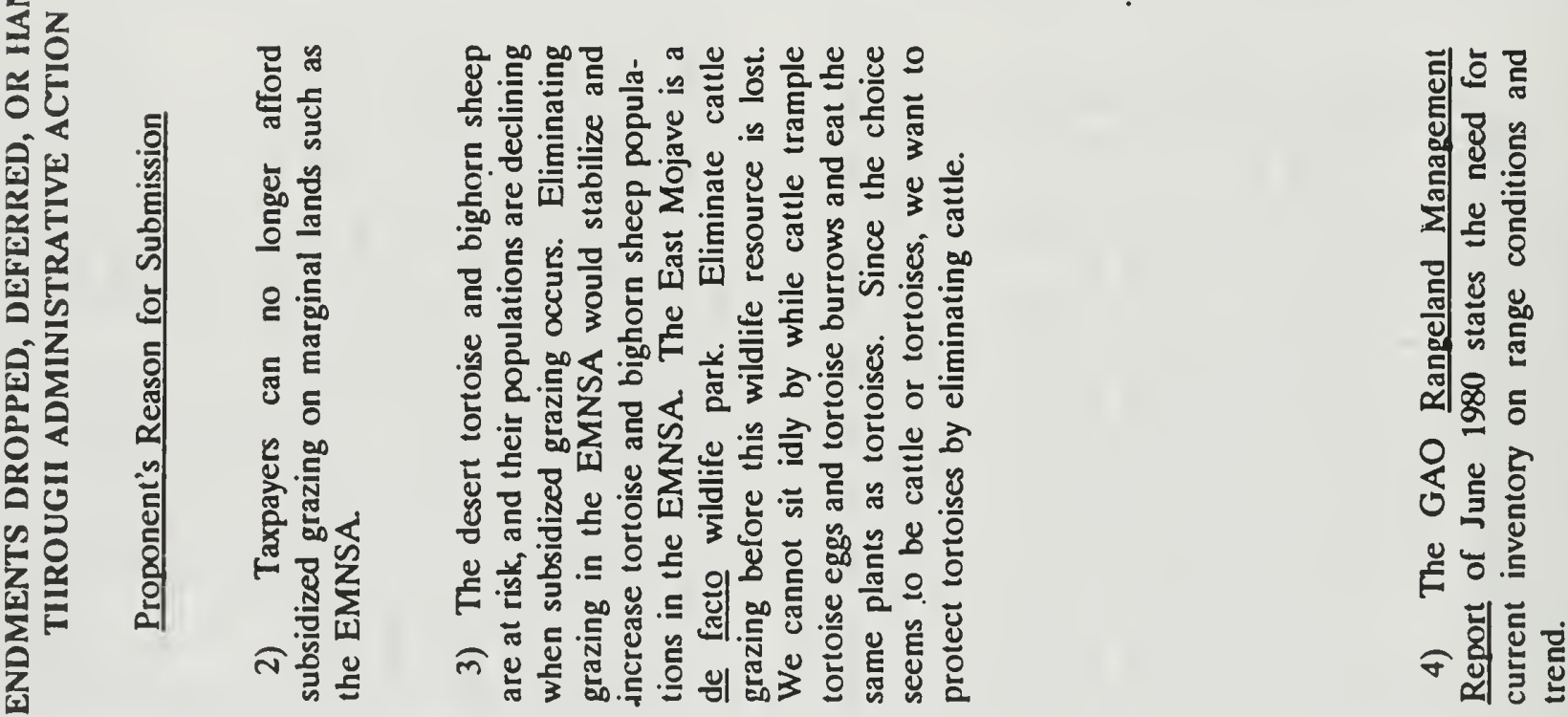

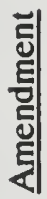

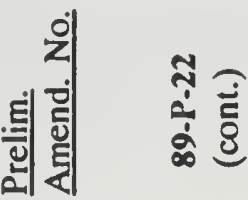



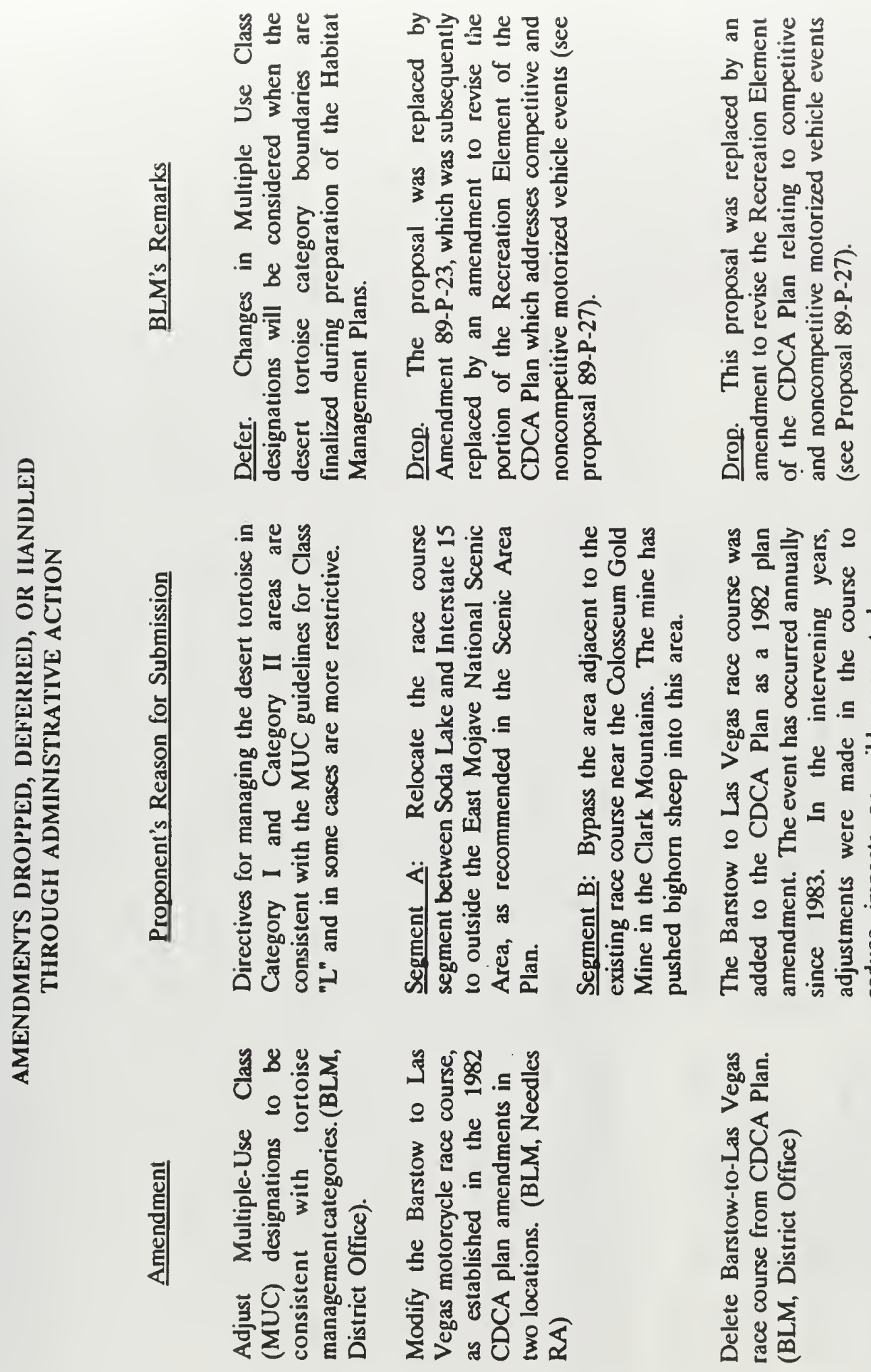

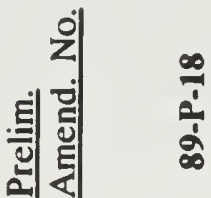

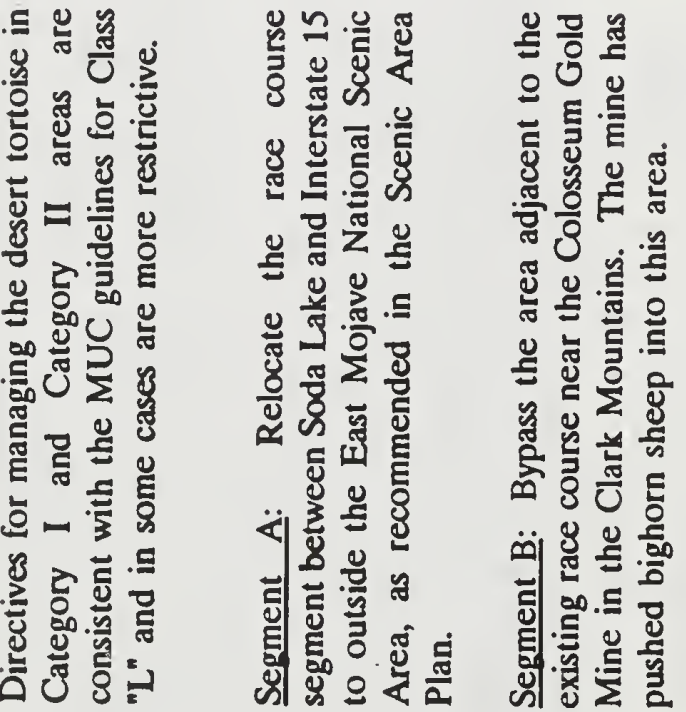

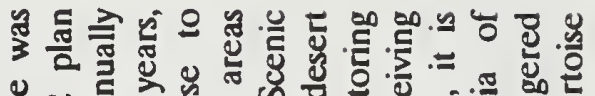

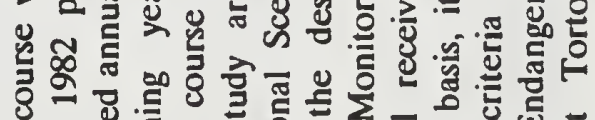
\%

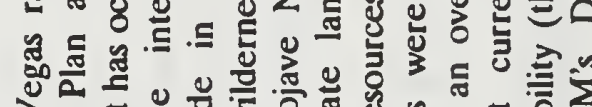

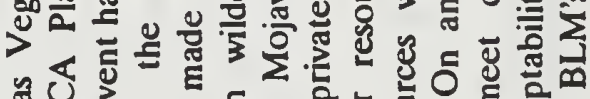
ว ○U

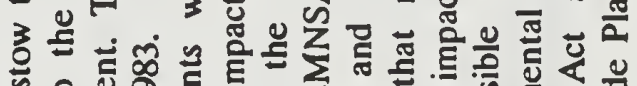

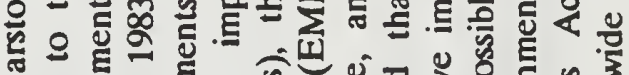

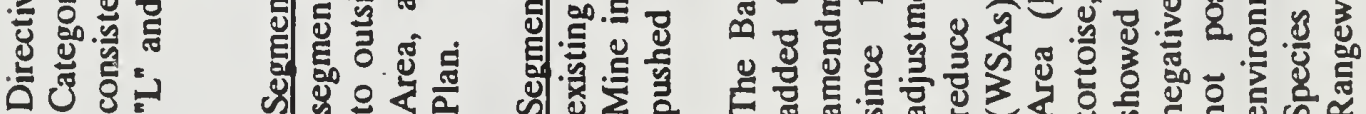

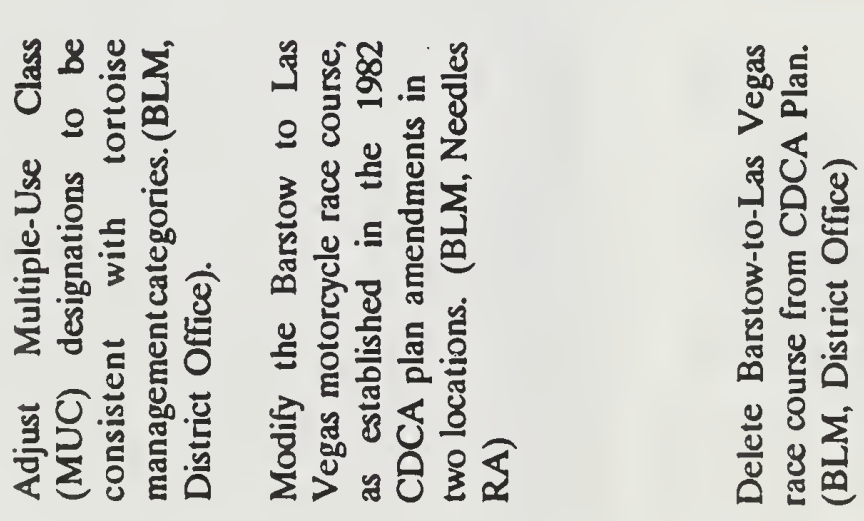




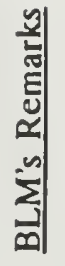

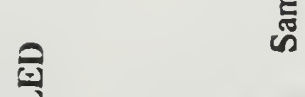

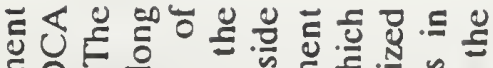
长期

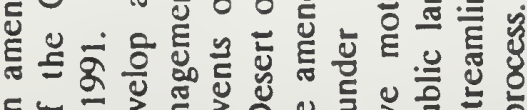
등 论

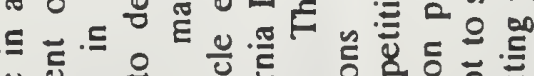

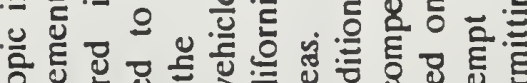

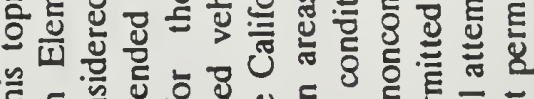

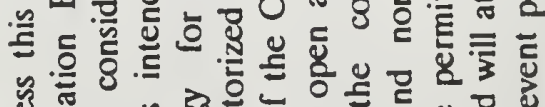

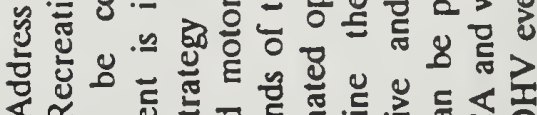

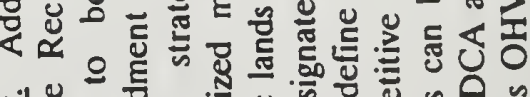

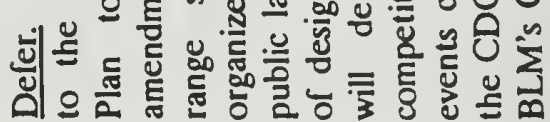

高

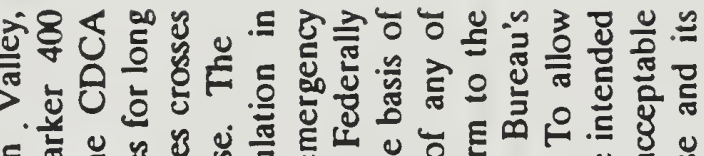
ธ듀.

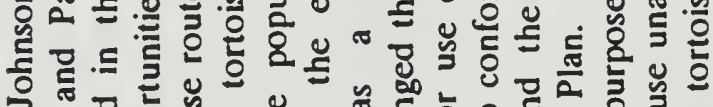

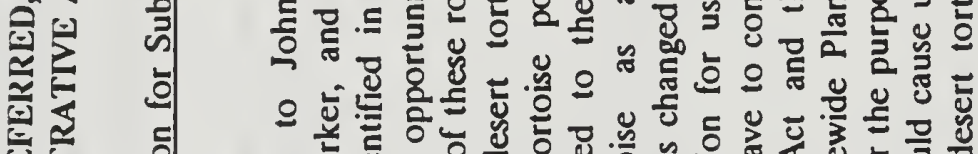

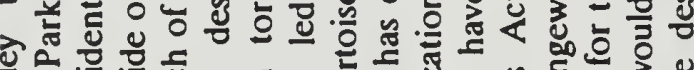

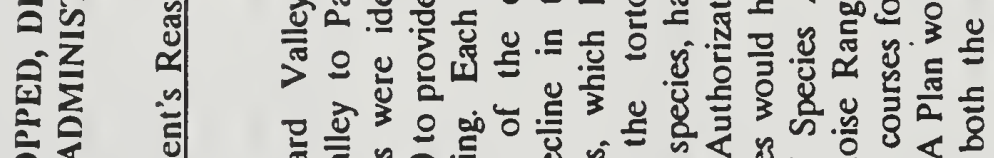

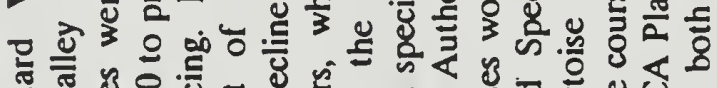

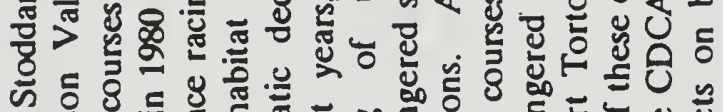
क के

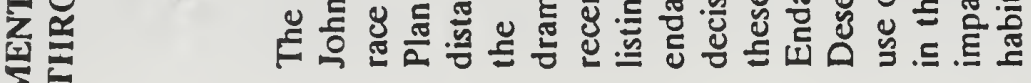
$\sum_{\substack{c \\ c}}$

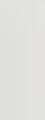

형

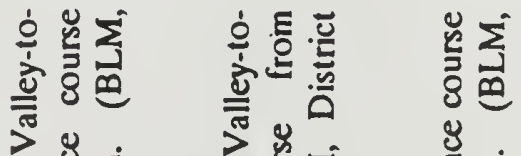

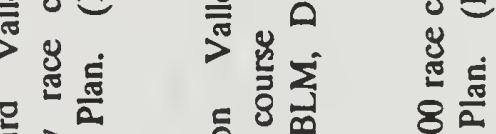

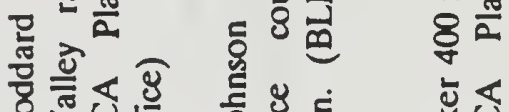

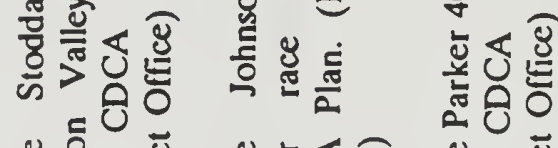

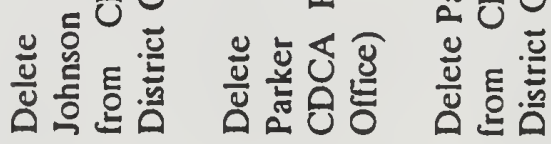

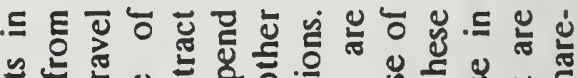

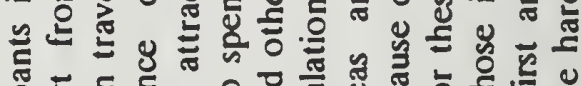

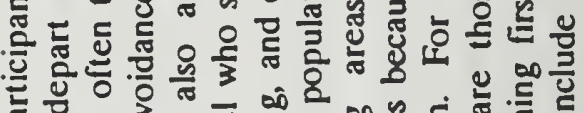

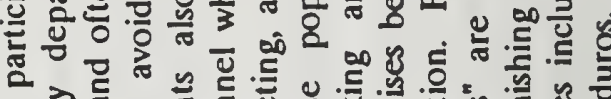

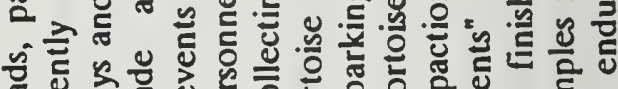

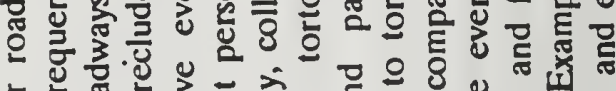

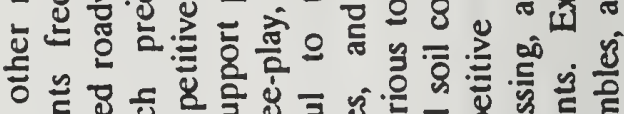

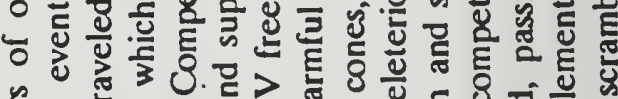
है

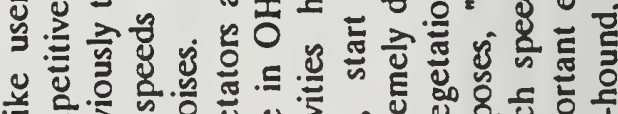
资

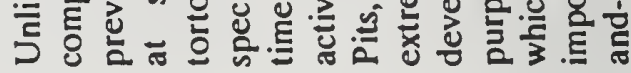

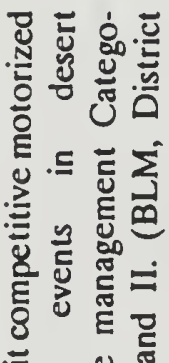

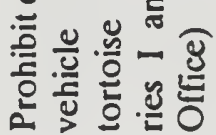

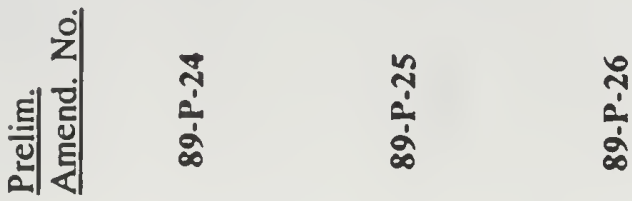




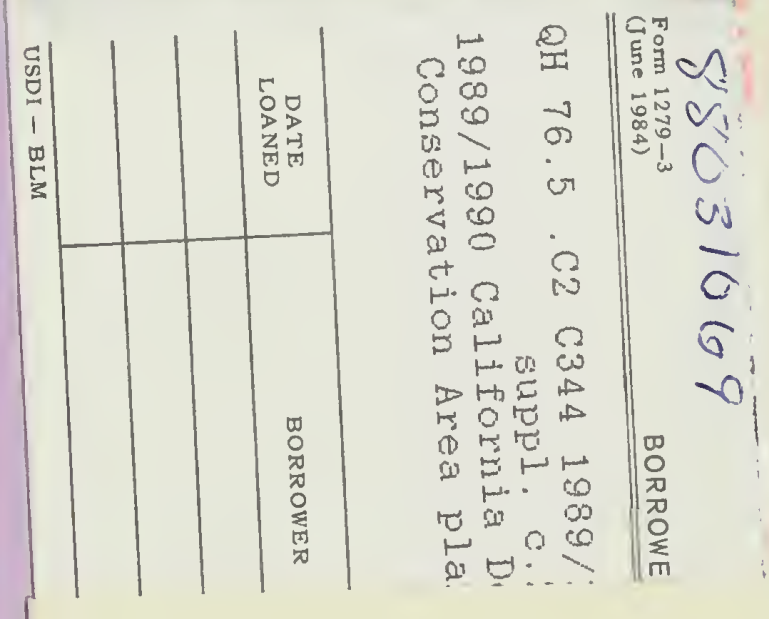

\author{
BLM LIBRARY \\ DENVER FEDG. 50 \\ P. O. BOX 25047
DENVENTER$$
\text { , CO 80225-0047 }
$$ 
